\title{
Characterization of Seismic Noise at Selected Non-Urban Sites
}

Lindamae Peck, Peter Styles, and Sam Toon

March 2010

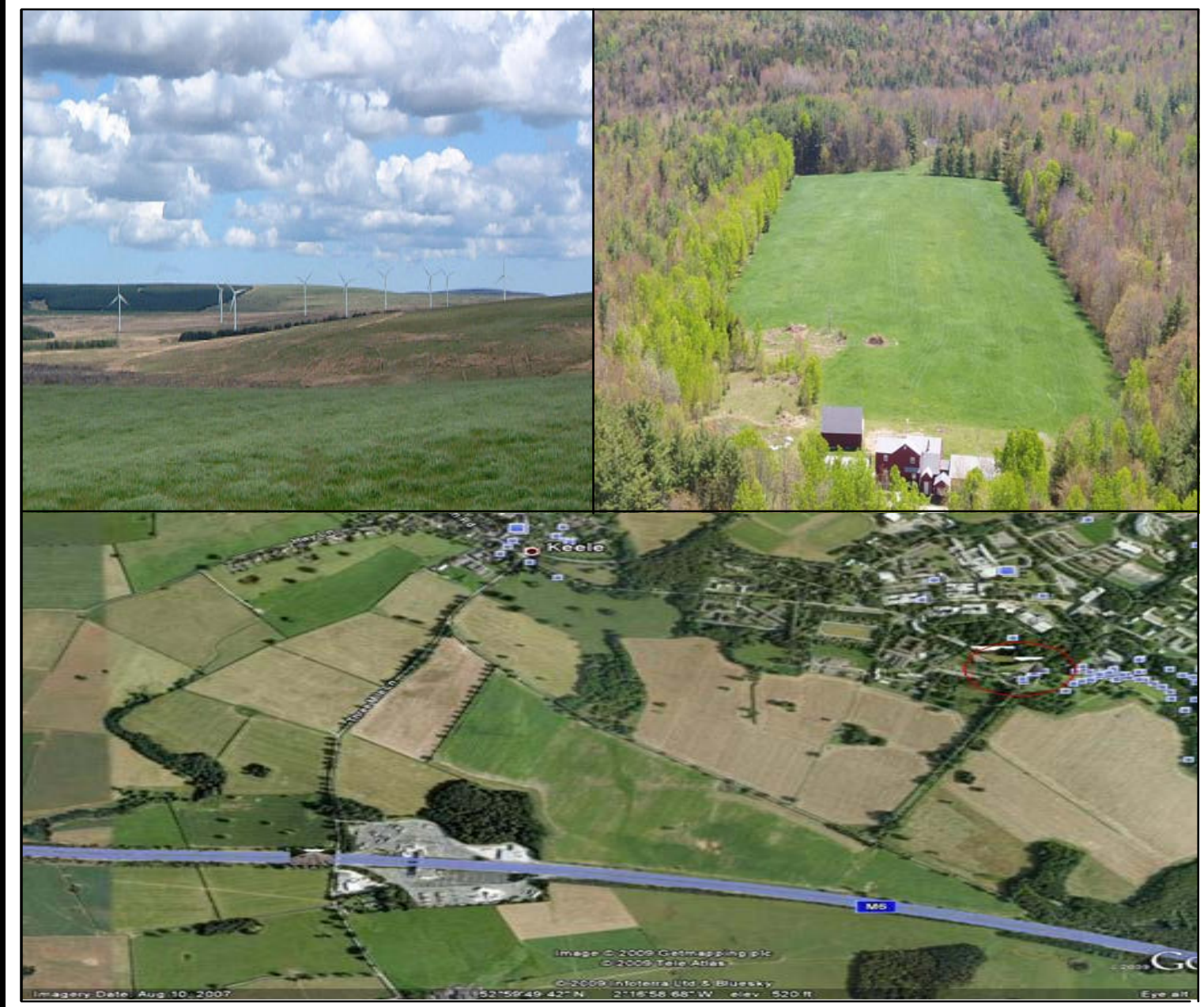

Approved for public release; distribution is unlimited. 
Field sites for seismic recordings: Scottish moor (upper left), Enfield, NH (upper right), and vicinity of Keele, England (bottom). 


\title{
Characterization of Seismic Noise at Selected Non-Urban Sites
}

\author{
Lindamae Peck ${ }^{1}$, Peter Styles ${ }^{2}$, and Sam Toon ${ }^{2}$ \\ ${ }^{1}$ Cold Regions Research and Engineering Laboratory \\ U.S .Army Engineer Research and Development Center \\ 72 Lyme Road, \\ Hanover, NH 03756 \\ 2Applied \& Environmental Geophysics Research Group \\ School of Physical and Geographical Sciences \\ Keele University, England
}

Final report

Approved for public release; distribution is unlimited.

Prepared for U.S. Army Corps of Engineers

Washington, DC 20314-1000 


\begin{abstract}
Seismic noise is the ambient ground motion within which signals of interest are to be detected. Because the distinction between seismic noise and seismic signature is application dependent, the ground motion representations presented in this report serve both as characterization of seismic noise that, for example, might interfere with the detection of walking people at the sites studied, and also as seismic signatures of the cultural activity at the three sites. The sites are: a wind farm on a remote moor in Scotland, a $\sim 13$ acre field bounded by woods in a rural Enfield, $\mathrm{NH}$ neighborhood, and a site transitional from developed to farmland within $1 \mathrm{~km}$ of the 6-lane M6 motorway near Keele, England. This report documents the variability in seismic noise at the three sites with site activity (wind farm), time of day (Enfield) and both time of day and day of the week (highway).
\end{abstract}

DISCLAIMER: The contents of this report are not to be used for advertising, publication, or promotional purposes. Citation of trade names does not constitute an official endorsement or approval of the use of such commercial products. All product names and trademarks cited are the property of their respective owners. The findings of this report are not to be construed as an official Department of the Army position unless so designated by other authorized documents. 


\section{Table of Contents}

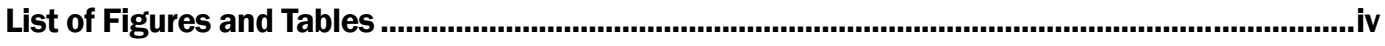

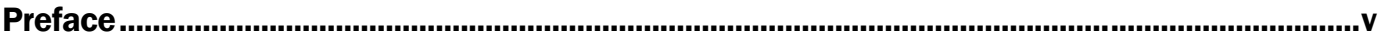

1 Introduction

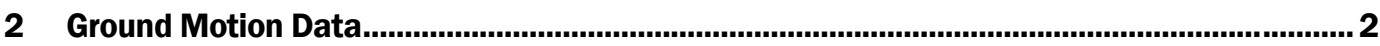

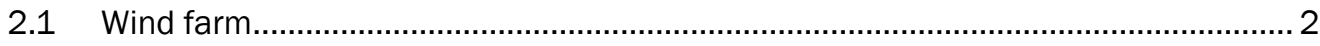

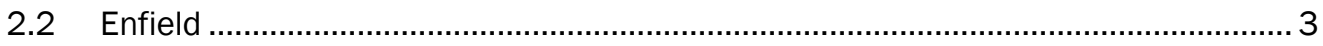

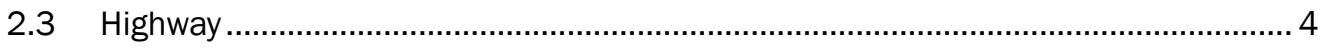

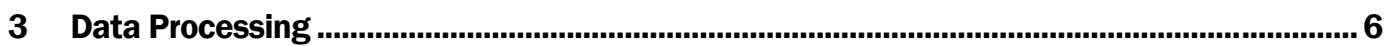

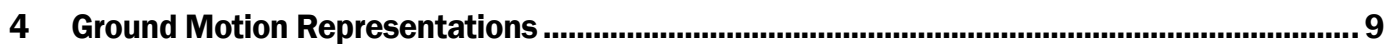

4.1 Wind farm

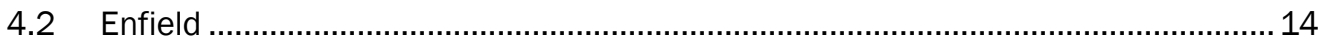

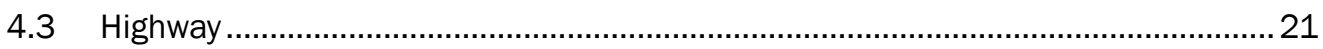

4.3.1 Hourly variation in vertical ground motion ......................................................21

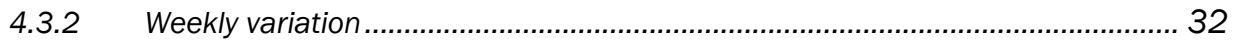

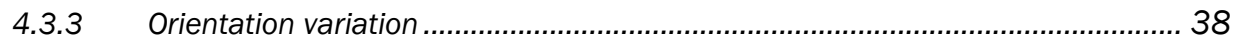

5 Curve Fitting

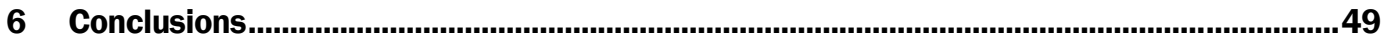

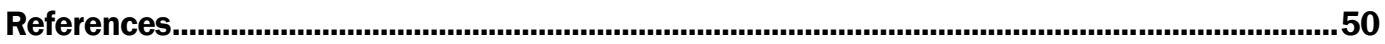

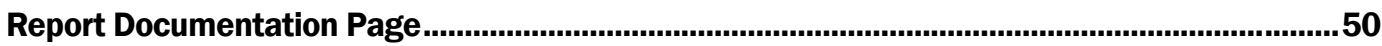




\section{List of Figures and Tables}

\section{Figures}

Figure 1. Portion of Dun Law wind farm. Towers are 40-m high. The three-bladed turbines are $47 \mathrm{~m}$ in diameter.

Figure 2. Aerial view of Enfield, $\mathrm{NH}$ site from the north. Vertical geophone was located in the foreground area of the field, $\sim 60 \mathrm{~m}$ from the edge of the woods to the west (right) and $\sim 45 \mathrm{~m}$ from the edge of the rough ground (scattered bushes separating grass field from woods) to the east (left).

Figure 3. Left: Google Earth view of highway site (at center of red circle in upper right corner) showing proximity to M6 and Keele University campus. Upper right: Photo of M6, which is $0.9 \mathrm{~km}$ from highway site at its closest point. Lower right: Photo of park area where seismometer is buried.

Figure 4. PDFs at (a) $4 \mathrm{~Hz}$ and (b) $20 \mathrm{~Hz}$ center frequency for vertical, east-west and north-south components of wind farm ground motion during the 50-min periods 0000 - 0050 (turbines turning) and 2240 - 2330 (turbines still) on 28 September 2004.

Figure 5. Power range of PDFs of wind farm ground motion by orientation, center frequency, and turbine activity. V, E, and $\mathrm{N}$ denote vertical, east-west, and northsouth components of ground motion, respectively. "On" and "off" refer to the turbines turning and still. The blue (red) bar indicates the selected lower (upper) limit of the principal portion of each power PDF.

Figure 6. Hourly power PDFs at 4-Hz center frequency for vertical ground motion for the period 0400 - 1200 GMT [0000 - 0800 local time] on 14 July 2005 at the Enfield field site.

Figure 7. Wind speed data recorded at the Enfield site. Data dropouts occurred during the 10-min periods beginning 0710, 0720, 0740, and 0750. Maximum, minimum, and average wind speeds were recorded every minute. The values plotted indicate the range in maxima and minima in each 10-min period.

Figure 8. Power range of PDFs of Enfield ground motion by center frequency and hour. The blue (red) bar indicates the selected lower (upper) limit of the principal portion of each power PDF. The $x$ axis identifies the hourly average PDF represented: 0400 - 1100 hr GMT, or 0000 - 0700 hr local time. The Y-axis upper limit is $1,1.5$ or 3 , depending on center frequency....

Figure 9. Hourly power PDFs at 4-Hz center frequency for vertical ground motion at the highway site on (a) Wednesday, 15 February 2006 and (b) Sunday, 19 February 2006. The PDFs are color coded with blues and greens for nighttime hours (1900 - 0600) and reds and oranges for daytime hours (0700 - 1800)

Figure 10.Power range of hourly PDFs of highway vertical ground motion by center frequency on Wednesday, 15 February 2006. The blue (red) bar indicates the selected lower (upper) limit of the principal portion of each power PDF. X-axis hourly designations are: 1 (0400), 2 (0900), 3 (1400), and 4 (1900). The y-axis upper limit is 1.5, 3, or $6 \times 10^{-10}$, depending on the center frequency. 31

Figure 11. Power range of hourly PDFs of highway vertical ground motion by center frequency on Sunday, 19 February 2006. The blue (red) bar indicates the selected lower (upper) limit of the principal portion of each power PDF. X-axis 
hourly designations are: 1 (0400), 2 (0900), 3 (1400) and 4 (1900). The y-axis

upper limit is 1.5 or $3 \times 10-10$, depending on the center frequency.

Figure 12. Power PDFs at 4-Hz center frequency for vertical ground motion at the highway site on seven days, 14 - 21 February 2006, during the hours of (a) 0000 0100 and (b) $0800-0900$.

Figure 13. Power range of PDFs of highway vertical ground motion by center frequency for the hours $0000-0100$ and $0800-0900$ on seven days, Wednesday, 15 February 2006, through Tuesday, 21 February 2006. The blue (red) bar indicates the selected lower (upper) limit of the principal portion of each power PDF. X-axis designations are 0 or 8 for 0000 or 0800 , respectively, and W, Th, F, Sa, Su, M, and Tu for Wednesday, Thursday, Friday, Saturday, Sunday, Monday, and Tuesday, respectively. The $y$-axis upper limit is 1,3 , or $6 \times 10^{-10}$, depending on the center frequency.

Figure 14. Power PDFs at $4 \mathrm{~Hz}$ center frequency for ground motion at the highway site on two days, Wednesday, 15 February and Sunday, 19 February 2006, during the hours of 0000 - 0100 and 0800 - 0900. (a) Vertical ground motion, (b) east-west horizontal ground motion, (c) north-south horizontal ground motion.

Figure 15. Power range of PDFs of highway ground motion by orientation, day, hour, and center frequency. The blue (red) bar indicates the selected lower (upper) limit of the principal portion of each power PDF. On the $x$ axis, $V$ denotes the vertical component of ground motion, $\mathrm{E}$ denotes the east-west component, and $\mathrm{N}$ denotes north-south; 1 denotes the 0000 hour on Wednesday, 15 February 2006; 2 denotes the $0800 \mathrm{hr}$ on that day; 3 denotes the $0000 \mathrm{hr}$ on Sunday, 19 February 2006; 4 denotes the $0800 \mathrm{hr}$ on that day. The y-axis upper limit is 3 or $6 \times 10^{-10}$, depending on center frequency.

Figure 16. Composite plots of wind farm, Enfield, and highway ground motion by frequency. The PDF curves are calculated from the ninth degree polynomial coefficients, with values of power defined by the lower and upper limits presented in Tables 2 - 4 and Tables 6 - 9, Tables 10 - 12, and Tables 13 - 15 for the wind farm, Enfield, highway (15 Feb 06), and highway (19 Feb 06) PDFs, respectively.

\section{Tables}

Table 1. Third-octave center frequencies of ground motion representations.

Table 2. Lower and upper limits of the principal portion of wind farm power PDFs by center frequency $(4-8 \mathrm{~Hz})$, ground motion orientation and turbine activity (turning, still). Units: $\mathrm{m}^{2} / \mathrm{s}^{2}$

Table 3 Lower and upper limits of the principal portion of wind farm power PDFs by center frequency $(10-20 \mathrm{~Hz})$, ground motion orientation and turbine activity (turning, still). Units: $\mathrm{m}^{2} / \mathrm{s}^{2}$

Table 4. Lower and upper limits of the principal portion of wind farm power PDFs by center frequency $(25-40 \mathrm{~Hz})$, ground motion orientation and turbine activity (turning, still). Units: $\mathrm{m}^{2} / \mathrm{s}^{2}$.

Table 5. Frequency content and wind speed threshold of wind noise (from Peck 2008).

Table 6. Lower and upper limits of the principal portion of Enfield power PDFs by center frequency $(4-10 \mathrm{~Hz})$ and hour. Vertical ground motion. Units: $\mathrm{m}^{2} / \mathrm{s}^{2}$.

Table 7. Lower and upper limits of the principal portion of Enfield power PDFs by center frequency $(12.5-31.5 \mathrm{~Hz})$ and hour. Vertical ground motion. Units: $\mathrm{m}^{2} / \mathrm{s}^{2}$. 
Table 8. Lower and upper limits of the principal portion of Enfield power PDFs by center frequency $(40-100 \mathrm{~Hz})$ and hour. Vertical ground motion. Units: $\mathrm{m}^{2} / \mathrm{s}^{2}$

Table 9. Lower and upper limits of the principal portion of Enfield power PDFs by center frequency $(125-200 \mathrm{~Hz})$ and hour. Vertical ground motion. Units: $\mathrm{m}^{2} / \mathrm{s}^{2}$

Table 10. Lower and upper limits of the principal portion of highway power PDFs by center frequency $(4 \mathrm{~Hz}-10 \mathrm{~Hz})$ and hour for Wednesday, 15 February 2006. Vertical ground motion. Units: $\mathrm{m}^{2} / \mathrm{s}^{2}$

Table 11. Lower and upper limits of the principal portion of highway power PDFs by center frequency $(12.5 \mathrm{~Hz}-31.5 \mathrm{~Hz})$ and hour for Wednesday, 15 February 2006. Vertical ground motion. Units: $\mathrm{m}^{2} / \mathrm{s}^{2}$.

Table 12. Lower and upper limits of the principal portion of highway power PDFs by center frequency $(40 \mathrm{~Hz}-80 \mathrm{~Hz})$ and hour for Wednesday, 15 February 2006. Vertical ground motion. Units: $\mathrm{m}^{2} / \mathrm{s}^{2}$.

Table 13. Lower and upper limits of the principal portion of highway power PDFs by center frequency $(4 \mathrm{~Hz}-10 \mathrm{~Hz}$ ) and hour for Sunday, 19 February 2006. Vertical ground motion. Units: $\mathrm{m}^{2} / \mathrm{s}^{2}$

Table 14. Lower and upper limits of the principal portion of highway power PDFs by center frequency $(12.5 \mathrm{~Hz}-31.5 \mathrm{~Hz})$ and hour for Sunday, 19 February 2006. Vertical ground motion. Units: $\mathrm{m}^{2} / \mathrm{s}^{2}$.

Table 15. Lower and upper limits of the principal portion of highway power PDFs by center frequency $(40 \mathrm{~Hz}-80 \mathrm{~Hz})$ and hour for Sunday, 19 February 2006. Vertical ground motion. Units: $\mathrm{m}^{2} / \mathrm{s}^{2}$

Table 16. Lower and upper limits of the principal portion of highway power PDFs by center frequency $(4 \mathrm{~Hz}-10 \mathrm{~Hz})$ for the hours of 0000 and 0800 on seven days, Wednesday, 15 February through Tuesday, 21 February 2006. Vertical ground motion. Units: $\mathrm{m}^{2} / \mathrm{s}^{2}$

Table 17. Lower and upper limits of the principal portion of highway power PDFs by center frequency $(12.5 \mathrm{~Hz}-31.5 \mathrm{~Hz})$ for the hours of 0000 and 0800 on seven days, Wednesday, 15 February through Tuesday, 21 February 2006. Vertical ground motion. Units: $\mathrm{m}^{2} / \mathrm{s}^{2}$

Table 18. Lower and upper limits of the principal portion of highway power PDFs by center frequency $(40 \mathrm{~Hz}-80 \mathrm{~Hz})$ for the hours of 0000 and 0800 on seven days, Wednesday, 15 February through Tuesday, 21 February 2006. Vertical ground motion. Units: $\mathrm{m}^{2} / \mathrm{s}^{2}$

Table 19. Lower and upper limits of the principal portion of highway power PDFs by center frequency (4 Hz - $10 \mathrm{~Hz}$ ) for the hours of 0000 and 0800 on Wednesday, 15 February and Sunday, 19 February 2006. Vertical (V), east-west horizontal (E-W) and north-south (N-S) horizontal ground motion. Units: $\mathrm{m}^{2} / \mathrm{s}^{2}$.

Table 20. Lower and upper limits of the principal portion of highway power PDFs by center frequency $(12.5 \mathrm{~Hz}-31.5 \mathrm{~Hz})$ for the hours of 0000 and 0800 on Wednesday, 15 February and Sunday, 19 February 2006. Vertical (V), east-west horizontal (E$\mathrm{W})$ and north-south (N-S) horizontal ground motion. Units: $\mathrm{m}^{2} / \mathrm{s}^{2}$.

Table 21. Lower and upper limits of the principal portion of highway power PDFs by center frequency $(40 \mathrm{~Hz}-80 \mathrm{~Hz})$ for the hours of 0000 and 0800 on Wednesday, 15 February and Sunday, 19 February 2006. Vertical (V), east-west horizontal (E-W) and north-south (N-S) horizontal ground motion. Units: $\mathrm{m}^{2} / \mathrm{s}^{2}$. 


\section{Preface}

This study was conducted for the U.S. Army under the Engineer Research and Development Center (ERDC) Adaptive Protection program. The technical monitor was Dr. J. Michael Boteler.

Dr. Peck's work was performed by the Signature Physics Branch (RR-D) of the Research and Engineering Division (RR), ERDC - Cold Regions Research and Engineering Laboratory (CRREL). At the time of publication, Dr. Lindamae Peck was Acting Chief, CEERD-RR-D; Dr. J ustin Berman was Chief, CEERD-RR; and Mr. Randy Hill was the Acting Technical Director for Terrestrial and Geospatial Sciences. At the time of publication, the Deputy Director of CRREL was Dr. Lance Hansen, and the Director was Dr. Robert E. Davis.

COL Gary E. J ohnston was the Commander and Executive Director of ERDC, and Dr. J effrey Holland was the Director. 


\section{Introduction}

Seismic noise is the ambient ground motion within which signals of interest are to be detected. Because the distinction between seismic noise and seismic signature is application dependent, the ground motion representations presented in this report serve both as characterization of seismic noise that, for example, might interfere with the detection of walking people at the sites studied, and also as seismic signatures of cultural activity at the three sites. The sites are: a wind farm on a remote moor in Scotland, a 13-acre field bounded by woods in a rural Enfield, $\mathrm{NH}$, neighborhood, and a site transitional from developed land to farmland within $1 \mathrm{~km}$ of the six-lane M6 motorway near Keele, England. Sites are subsequently referred to as the wind farm, Enfield, and highway sites, respectively. The significance of the three sites lies in their contrast to urban settings.

This report documents the variability in seismic noise at the three sites with site activity (wind farm), time of day (Enfield) and both time of day and day of the week (highway). Vertical ground motion is investigated at all sites; horizontal components of wind farm and highway ground motion are also analyzed. For brevity, some ground motion representations included in the report are limited to selected frequencies. A complete set of results - all frequencies analyzed - is provided on CD. 


\section{Ground Motion Data}

No video record of the three sites during the periods of analyzed ground motion was available to aid in associating ground motion with source activity. For the wind farm site, energy production records enable determining whether the turbines are turning or still. Cultural activity and the coupling of wind energy, such as wind-induced movement of surface objects, are the primary potential sources of ground motion at the other two sites, but wind speed data are available only for the Enfield site. Variation in cultural activity at the Enfield and highway sites, although not documented, is expected because periods of analyzed ground motion intentionally span all or a substantial portion of $24 \mathrm{hr}$, and a diurnal pattern for Western cultural activity is common. Similarly, the M6 traffic that passes the highway site may have a regional commuter component and a local commercial component, both of which are likely to impart weekday vs. weekend differences in traffic-induced ground motion.

\subsection{Wind farm}

The Dun Law wind farm, with 26 turbines, is located $32 \mathrm{~km}$ southeast of Edinburgh, Scotland, on high moorland of the Lammermuir Hills (Figure 1). The near-surface formations are Ordovician/Silurian mudstones and shales with a peat cover. The area is treeless and unpopulated. The threecomponent (vertical, north-south horizontal, and east-west horizontal) ground motion data analyzed were collected by Professor Peter Styles, and the Applied and Environmental Geophysics Group, Keele University, England, with a Guralp CMG-6TD digital broadband seismometer at a sampling frequency of $100 \mathrm{~Hz}$ in hourly time blocks. The seismometer site is $5,242 \mathrm{~m}$ from the northwest point of the wind farm. The instrument was installed in an 80-cm-deep hole packed with sand. Two 50-min periods on 28 September 2004, 0000 - 0050 and 2240-2330 GMT, were selected for analysis, corresponding to strong (light) winds when the wind turbines were (were not) turning, respectively. Wind speed measurements were $9.5-11.3 \mathrm{~m} / \mathrm{s}$ average, $13.5-16 \mathrm{~m} / \mathrm{s}$ maximum during $0000-0050 \mathrm{hrs}$, and $0.6-2.3 \mathrm{~m} / \mathrm{s}$ average, $1.2-2.9 \mathrm{~m} / \mathrm{s}$ maximum during $2240-2330$. All wind farm data were post-processed with a 2-Hz highpass filter. Wind farm ground motion velocity was $\sim 0.5 \times 10^{-6} \mathrm{~m} / \mathrm{s}$. 


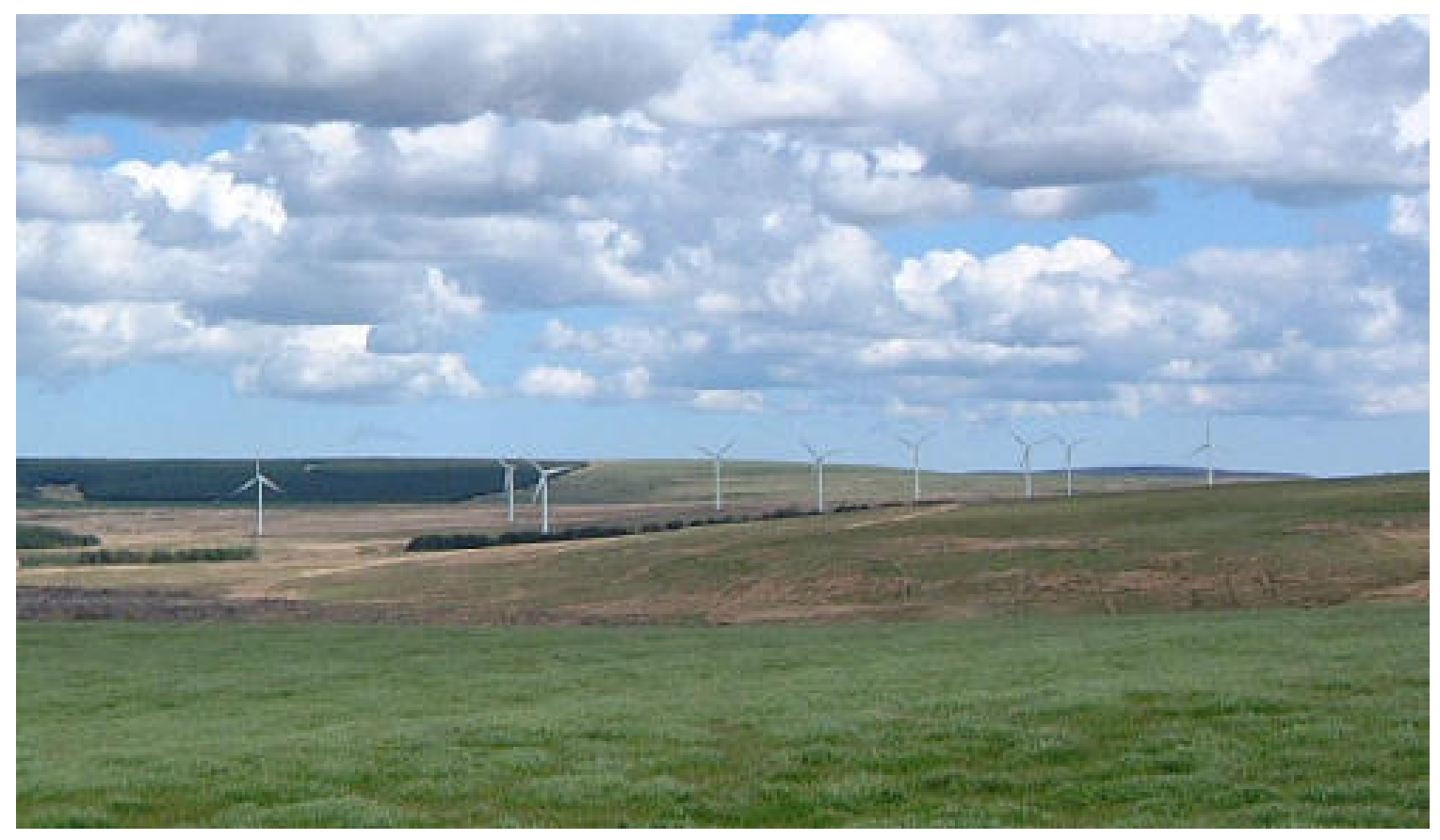

Figure 1. Portion of Dun Law wind farm. Towers are 40-m high. The three-bladed turbines are $47 \mathrm{~m}$ in diameter.

\subsection{Enfield}

Enfield ground motion was recorded at the east-west midpoint of an open field (Figure 2). The field is 500-m long and varies in width from $105 \mathrm{~m}$ (instrument site in northern portion of field) to $130 \mathrm{~m}$. Two houses are at the northern edge of the field. The field is bounded by woods on the other three sides. Town roads are present $200 \mathrm{~m}$ to the west, $150 \mathrm{~m}$ to the south, and 600 - $700 \mathrm{~m}$ to the east. An 8-hr block of vertical ground motion data was analyzed, corresponding from midnight to $0800 \mathrm{hr}$ local time on Thursday, 14 J uly 2005. [The data files are identified as 0400 to 1200 GMT, in the convention of the recording system.] The expectation was that the 8-hr period would span a cycle of decreasing cultural activity, minimal activity (perhaps 0100 - $0500 \mathrm{hr}$ local time), and then increasing activity. The motion transducer was a $4.5-\mathrm{Hz}$ geophone at the ground surface. Data were collected with a Geometrics system at a sampling frequency of 500 $\mathrm{Hz}$. Ground motion velocity was quite variable over time scales of seconds and minutes, ranging from $\sim 1-10 \times 10^{-6} \mathrm{~m} / \mathrm{s}$ throughout the 8- $\mathrm{hr}$ period. 


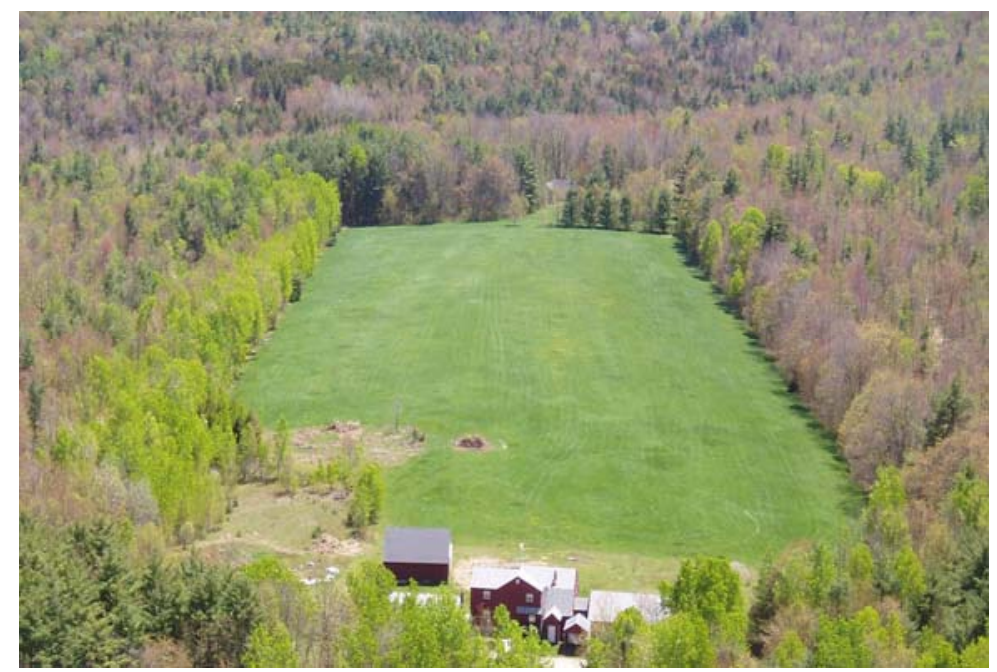

Figure 2. Aerial view of Enfield, $\mathrm{NH}$ site from the north. Vertical geophone was located in the foreground area of the field, $\sim 60 \mathrm{~m}$ from the edge of the woods to the west (right) and $\sim 45 \mathrm{~m}$ from the edge of the rough ground (scattered bushes separating grass field from woods) to the east (left).

\subsection{Highway}

Ground motion data were recorded $\sim 0.9 \mathrm{~km}$ from the M6, which is the central commercial route between Scotland and London and perhaps the busiest motorway in England. Data were collected by Prof. Peter Styles and the Applied and Environmental Geophysics Group, Keele University, England, with a Guralp three-axis digital seismometer at a sampling frequency of $200 \mathrm{~Hz}$ and recorded in hourly blocks. The seismometer location is a park on the periphery of the Keele University campus, with farmland between it and the M6 (Figure 3). The M6 descends in elevation from $\sim 160 \mathrm{~m}$ to $\sim 144 \mathrm{~m}$ right to left in the image; the seismometer elevation is $\sim 190 \mathrm{~m}$. Data analyzed span seven days from $15-21$ February 2006. Vertical component ground motion was analyzed for two, 24-hr periods (0000 - $2400 \mathrm{hr}$ on Wednesday, 15 February and Sunday, 19 February) and for two 1-hr time blocks (0000 - 0100 and 0800 - 0900) on 15 - 21 February. East-west and north-south ground motion components were analyzed for the hours 0000 - 0100 and 0800 - 0900 on 15 and 19 February. Vertical ground motion velocity varies over the course of a day: $\sim 8-12 \times 10^{-6} \mathrm{~m} / \mathrm{s}$ on Wednesday and $\sim 4-5 \times 10^{-6} \mathrm{~m} / \mathrm{s}$ on Sunday. 

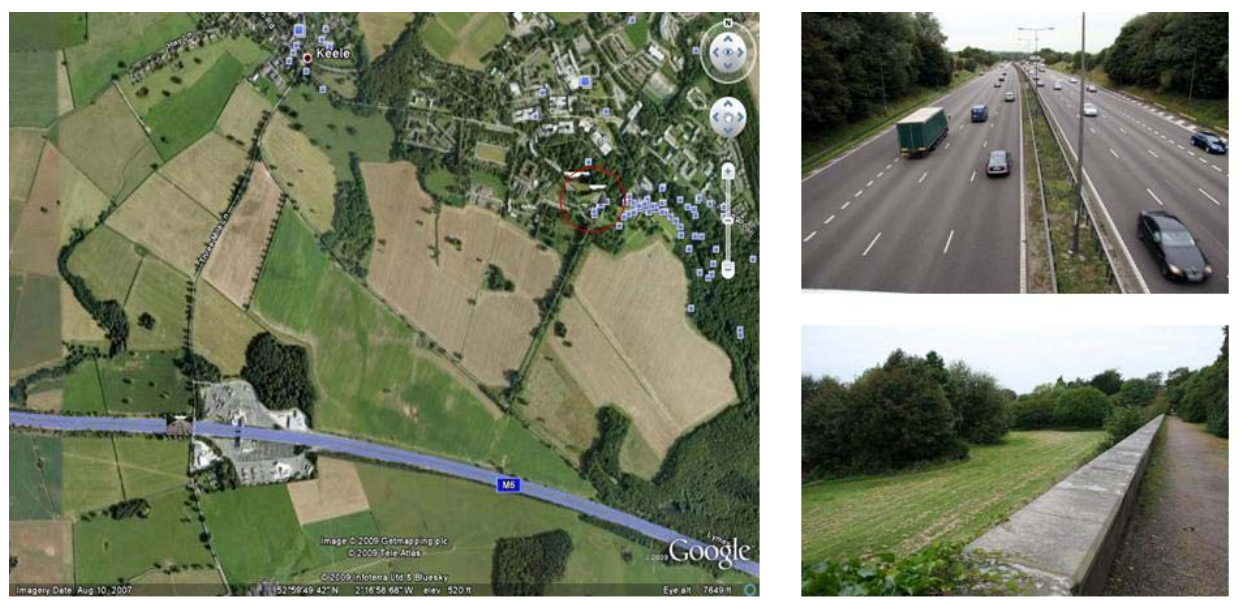

Figure 3. Left: Google Earth view of highway site (at center of red circle in upper right corner) showing proximity to $\mathrm{M} 6$ and Keele University campus. Upper right: Photo of M6, which is $0.9 \mathrm{~km}$ from highway site at its closest point. Lower right: Photo of park area where seismometer is buried. 


\section{Data Processing}

The Guralp and Geometrics systems automatically apply anti-aliasing filters during data collection. Pre-amplifier gain is removed either prior to the data being written to file (Geometrics) or by running recorded data through a routine that also calibrates the data (Guralp). A different routine is applied to calibrate the Geometrics data.

Ground motion at the three sites is analyzed in the frequency domain by means of the Fourier transform. In all cases, the data block length is $4 \mathrm{~s}$, the overlap between data blocks is $75 \%$, a Hanning taper is applied in windowing the data, and the data block is padded by a factor of four. The resultant frequency interval is $0.0625 \mathrm{~Hz}$. The wind farm data only are processed with a $2-\mathrm{Hz}$ highpass filter to remove low frequency components associated with wave-induced microseisms that propagate inland from

the coast.

The time block of interest for both the Enfield data and the highway data is $60 \mathrm{~min}$, i.e., ground motion is assessed by its variability from hour to hour. The wind farm data, being limited to two, 50-min-long time blocks, is assessed by comparison of those two time periods corresponding to the turbines turning and still. For all sites, a time block is divided into 10-minlong sub-blocks. The Fourier transform is applied to each time sub-block, in $4 \mathrm{~s}$ data blocks as described above, and the complex modulus is calculated at each frequency. A magnitude matrix is created for each time subblock: wind farm matrices are 801 x 597, Enfield matrices are 4001 x 598, and highway matrices are $1601 \times 597$, where the rows correspond to frequency and the columns to time. Magnitudes are converted to power by squaring.

The number of frequencies is reduced by averaging over frequency in onethird octave intervals beginning at $4 \mathrm{~Hz}$ (Table I). The maximum center frequency varies among the three sites ( $40 \mathrm{~Hz}$ for wind farm data, $80 \mathrm{~Hz}$ for highway data, and $200 \mathrm{~Hz}$ for Enfield data) because of differences in sampling rate during data collection. The corresponding number of center frequencies is 11,14 , or 18 . The resultant power matrix for each center frequency is 1 x 597 (1 x 598 for Enfield data). 
Table 1. Third-octave center frequencies of ground motion representations.

\begin{tabular}{|c|c|c|c|c|}
\hline $\begin{array}{l}\text { Center } \\
\text { Frequency } \\
(\mathrm{Hz})\end{array}$ & Wind Farm & Highway & Enfield & $\begin{array}{l}\text { Frequency } \\
\text { Range }(\mathrm{Hz})\end{array}$ \\
\hline 4 & $x$ & $x$ & $x$ & $3.5-4.4$ \\
\hline 5 & $x$ & $x$ & $x$ & $4.4-5.6$ \\
\hline 6 & $x$ & $x$ & $x$ & $5.6-7.0$ \\
\hline 8 & $x$ & $x$ & $x$ & $7.0-8.9$ \\
\hline 10 & $x$ & $x$ & $x$ & $8.9-11.2$ \\
\hline 12.5 & $x$ & $x$ & $x$ & $11.2-14.1$ \\
\hline 16 & $x$ & $x$ & $x$ & $14.1-17.8$ \\
\hline 20 & $x$ & $x$ & $x$ & $17.8-22.4$ \\
\hline 25 & $x$ & $x$ & $x$ & $22.4-28.2$ \\
\hline 31.5 & $x$ & $x$ & $x$ & $28.2-35.5$ \\
\hline 40 & $x$ & $x$ & $x$ & $35.5-44.7$ \\
\hline 50 & & $x$ & $x$ & $44.7-56.2$ \\
\hline 63 & & $x$ & $x$ & $56.2-70.8$ \\
\hline 80 & & $x$ & $x$ & $70.8-89.1$ \\
\hline 100 & & & $x$ & $89.1-112$ \\
\hline 125 & & & $x$ & $112-141$ \\
\hline 160 & & & $x$ & $141-178$ \\
\hline 200 & & & $x$ & $178-224$ \\
\hline
\end{tabular}

A power histogram is generated for each 10 -min power matrix, and normalized as a probability density function (PDF) using the MatLab function trapz. Histogram power bins and counts, and PDF values for each 10-min period, are provided on the accompanying CD.

For this report, each set of six 10-min power matrices for a given hour and center frequency is averaged to generate a single (1 x 597 or 1 x 598) power matrix for that hour and center frequency. Next, a power histogram for each center frequency and hour is generated from its average power matrix and normalized as a PDF using the MatLab function trapz. The result is one PDF per center frequency at each hour of Enfield and highway ground motion. For the wind farm data, the result is one PDF per center frequency for the 50 min of ground motion while the turbines are turning, and one 
PDF per center frequency for the 50 min while the turbines are still. Hourly histogram and PDF values are provided on the accompanying CD. 


\section{Ground Motion Representations}

Ground motion is presented as a PDF of power by center frequency and hour at third-octave intervals.

\subsection{Wind farm}

Wind farm PDF plots by ground motion orientation and turbine activity were generated for center frequencies of 4 to $40 \mathrm{~Hz}$. The $4-\mathrm{Hz}$ and $20-\mathrm{Hz}$ sets are shown as examples in Figure 4. [PDF plots for the other frequencies are included on the accompanying CD.] While the turbines are still, ground motion is distinctly different by orientation at frequencies of $4-10$ $\mathrm{Hz}$, with the vertical component the strongest and the east-west component the weakest (e.g., Figure 4a); at frequencies of 12.5 - $40 \mathrm{~Hz}$, however, vertical and north-south components are very similar (e.g., Figure 4b). While the turbines are turning, ground motion shows little variation by orientation.

The relative smoothness of the 'turbine turning' PDFs is consistent with the turbine movement being a forcing function for ground motion that persists throughout the 50-min time block. The 'turbine still' PDFs display more irregularity, which is attributed to the greater randomness of ground motion during that 50-min time block.

A power range with each wind farm PDF was determined by visual inspection of the plots. The upper and lower limits of the power range are not the extreme limits of the PDF; rather, they are a subjective determination of the principal portion of a PDF range, excluding low amplitude oscillatory tails. The selected limits were tabulated for each center frequency (Tables 2 - 4) and plotted (Figure 5). For all center frequencies, ground motion while the turbines are turning is stronger than while the turbines are still. 

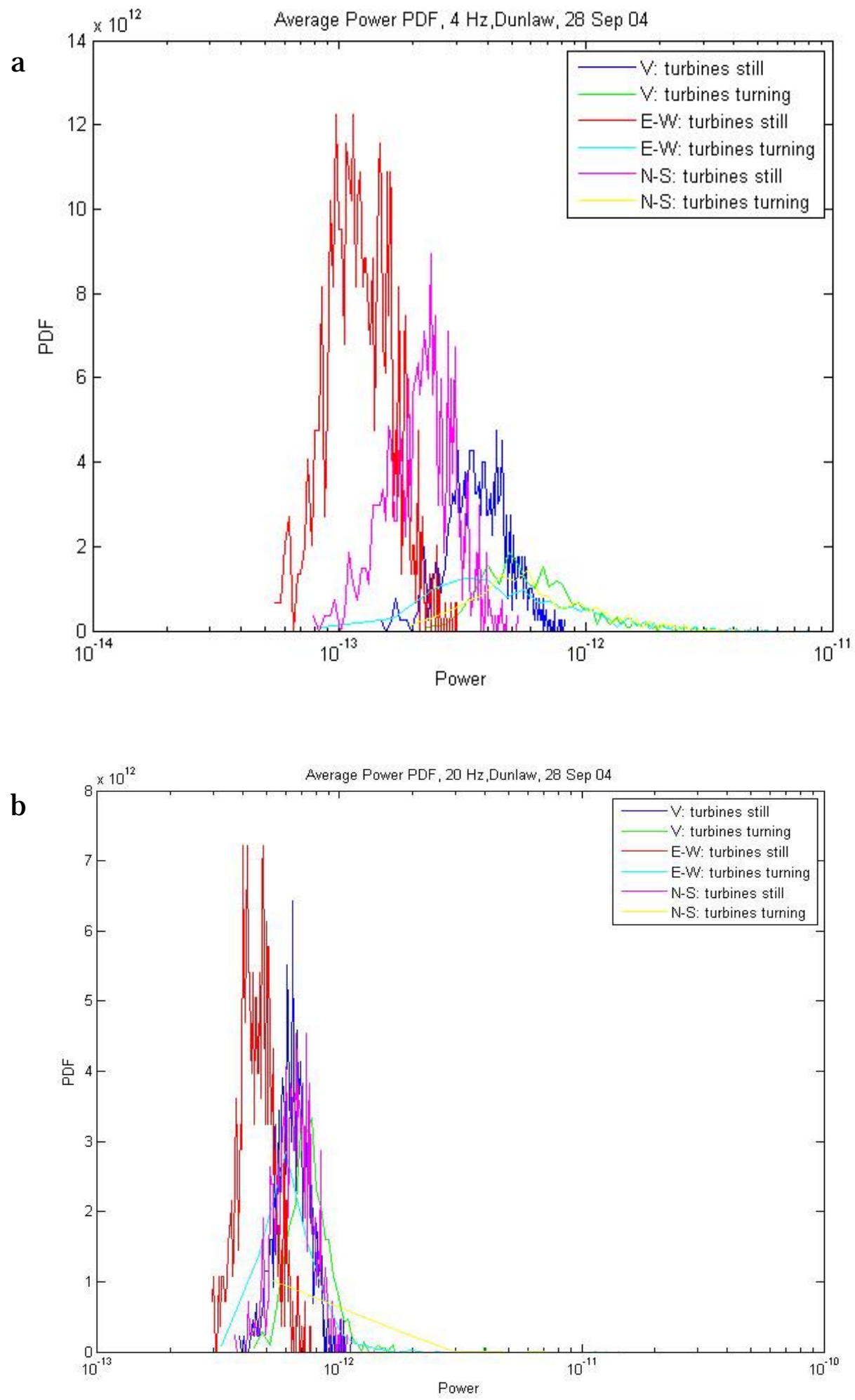

Figure 4. PDFs at (a) $4 \mathrm{~Hz}$ and (b) $20 \mathrm{~Hz}$ center frequency for vertical, east-west and northsouth components of wind farm ground motion during the 50-min periods 0000 - 0050 (turbines turning) and 2240 - 2330 (turbines still) on 28 September 2004. 
Table 2. Lower and upper limits of the principal portion of wind farm power PDFs by center frequency $(4-8 \mathrm{~Hz})$, ground motion orientation and turbine activity (turning, still).

Units: $\mathrm{m}^{2} / \mathrm{s}^{2}$.

\begin{tabular}{|l|l|l|l|l|l|l|l|l|}
\hline \multirow{2}{*}{\begin{tabular}{l} 
Activity \\
\cline { 2 - 9 }
\end{tabular}} & $\begin{array}{l}\text { Lower } \\
\text { Limit }\end{array}$ & $\begin{array}{l}\text { Upper } \\
\text { Limit }\end{array}$ & $\begin{array}{l}\text { Lower } \\
\text { Limit }\end{array}$ & $\begin{array}{l}\text { Upper } \\
\text { Limit }\end{array}$ & $\begin{array}{l}\text { Lower } \\
\text { Limit }\end{array}$ & $\begin{array}{l}\text { Upper } \\
\text { Limit }\end{array}$ & $\begin{array}{l}\text { Lower } \\
\text { Limit }\end{array}$ & $\begin{array}{l}\text { Upper } \\
\text { Limit }\end{array}$ \\
\hline V Still & $1.96 E-13$ & $6.77 \mathrm{E}-13$ & $1.50 \mathrm{E}-13$ & $4.69 \mathrm{E}-13$ & $1.45 \mathrm{E}-13$ & $3.70 \mathrm{E}-13$ & $1.23 \mathrm{E}-13$ & $2.96 \mathrm{E}-13$ \\
\hline $\begin{array}{l}\text { V } \\
\text { Turning }\end{array}$ & $2.24 \mathrm{E}-13$ & $1.52 \mathrm{E}-12$ & $2.34 \mathrm{E}-13$ & $1.02 \mathrm{E}-12$ & $1.46 \mathrm{E}-13$ & $6.76 \mathrm{E}-13$ & $1.35 \mathrm{E}-13$ & $5.34 \mathrm{E}-13$ \\
\hline E-W Still & $6.51 \mathrm{E}-14$ & $2.25 \mathrm{E}-13$ & $6.29 \mathrm{E}-14$ & $1.58 \mathrm{E}-13$ & $5.71 \mathrm{E}-14$ & $1.49 \mathrm{E}-13$ & $6.89 \mathrm{E}-14$ & $1.54 \mathrm{E}-13$ \\
\hline $\begin{array}{l}\text { E-W } \\
\text { Turning }\end{array}$ & $8.56 \mathrm{E}-14$ & $2.21 \mathrm{E}-12$ & $9.56 \mathrm{E}-14$ & $1.15 \mathrm{E}-12$ & $7.43 \mathrm{E}-14$ & $5.54 \mathrm{E}-13$ & $7.50 \mathrm{E}-14$ & $4.19 \mathrm{E}-13$ \\
\hline N-S Still & $1.05 \mathrm{E}-13$ & $3.75 \mathrm{E}-13$ & $9.44 \mathrm{E}-14$ & $3.08 \mathrm{E}-13$ & $9.27 \mathrm{E}-14$ & $2.50 \mathrm{E}-13$ & $8.80 \mathrm{E}-14$ & $2.44 \mathrm{E}-13$ \\
\hline $\begin{array}{l}\text { N-S } \\
\text { Turning }\end{array}$ & $1.93 \mathrm{E}-13$ & $2.00 \mathrm{E}-12$ & $1.41 \mathrm{E}-13$ & $1.13 \mathrm{E}-12$ & $9.91 \mathrm{E}-14$ & $7.03 \mathrm{E}-13$ & $1.14 \mathrm{E}-13$ & $4.38 \mathrm{E}-13$ \\
\hline
\end{tabular}

Table 3 Lower and upper limits of the principal portion of wind farm power PDFs by center frequency $(10-20 \mathrm{~Hz})$, ground motion orientation and turbine activity (turning, still).

Units: $\mathrm{m}^{2} / \mathrm{s}^{2}$.

\begin{tabular}{|l|l|l|l|l|l|l|l|l|}
\hline \multirow{2}{*}{\begin{tabular}{l} 
Activity \\
\cline { 2 - 9 }
\end{tabular}} & $\begin{array}{l}\text { Lower } \\
\text { Limit }\end{array}$ & $\begin{array}{l}\text { Upper } \\
\text { Limit }\end{array}$ & $\begin{array}{l}\text { Lower } \\
\text { Limit }\end{array}$ & $\begin{array}{l}\text { Upper } \\
\text { Limit }\end{array}$ & $\begin{array}{l}\text { Lower } \\
\text { Limit }\end{array}$ & $\begin{array}{l}\text { Upper } \\
\text { Limit }\end{array}$ & $\begin{array}{l}\text { Lower } \\
\text { Limit }\end{array}$ & $\begin{array}{l}\text { Upper } \\
\text { Limit }\end{array}$ \\
\hline V Still & $1.14 \mathrm{E}-13$ & $2.76 \mathrm{E}-13$ & $1.56 \mathrm{E}-13$ & $3.76 \mathrm{E}-13$ & $2.82 \mathrm{E}-13$ & $5.31 \mathrm{E}-13$ & $4.67 \mathrm{E}-13$ & $8.54 \mathrm{E}-13$ \\
\hline V Turning & $1.36 \mathrm{E}-13$ & $5.78 \mathrm{E}-13$ & $1.76 \mathrm{E}-13$ & $\begin{array}{l}7.17 \\
\text { E-13 }\end{array}$ & $2.61 \mathrm{E}-13$ & $8.36 \mathrm{E}-13$ & $5.14 \mathrm{E}-13$ & $1.19 \mathrm{E}-12$ \\
\hline E-W Still & $8.27 \mathrm{E}-14$ & $1.82 \mathrm{E}-13$ & $1.27 \mathrm{E}-13$ & $2.75 \mathrm{E}-13$ & $2.03 \mathrm{E}-13$ & $4.07 \mathrm{E}-13$ & $3.21 \mathrm{E}-13$ & $5.96 \mathrm{E}-13$ \\
\hline $\begin{array}{l}\text { E-W } \\
\text { Turning }\end{array}$ & $8.85 \mathrm{E}-14$ & $3.47 \mathrm{E}-13$ & $1.31 \mathrm{E}-13$ & $3.93 \mathrm{E}-13$ & $2.19 \mathrm{E}-13$ & $5.55 \mathrm{E}-13$ & $3.25 \mathrm{E}-13$ & $1.29 \mathrm{E}-12$ \\
\hline N-S Still & $1.16 \mathrm{E}-13$ & $2.41 \mathrm{E}-13$ & $1.69 \mathrm{E}-13$ & $3.54 \mathrm{E}-13$ & $2.70 \mathrm{E}-13$ & $5.34 \mathrm{E}-13$ & $4.54 \mathrm{E}-13$ & $9.10 \mathrm{E}-13$ \\
\hline $\begin{array}{l}\text { N-S } \\
\text { Turning }\end{array}$ & $1.74 \mathrm{E}-13$ & $5.48 \mathrm{E}-13$ & $1.84 \mathrm{E}-13$ & $6.48 \mathrm{E}-13$ & $2.92 \mathrm{E}-13$ & $9.36 \mathrm{E}-13$ & $5.34 \mathrm{E}-13$ & $2.96 \mathrm{E}-12$ \\
\hline
\end{tabular}


Table 4. Lower and upper limits of the principal portion of wind farm power PDFs by center frequency $(25-40 \mathrm{~Hz})$, ground motion orientation and turbine activity (turning, still). Units: $\mathrm{m}^{2} / \mathrm{s}^{2}$.

\begin{tabular}{|l|l|l|l|l|l|l|}
\hline \multirow{2}{*}{ Activity } & \multicolumn{2}{|c|}{$25 \mathrm{~Hz}$} & \multicolumn{2}{c|}{$31.5 \mathrm{~Hz}$} & \multicolumn{2}{c|}{$40 \mathrm{~Hz}$} \\
\cline { 2 - 7 } & Lower Limit & Upper Limit & Lower Limit & Upper Limit & Lower Limit & Upper Limit \\
\hline V Still & $8.16 \mathrm{E}-13$ & $1.40 \mathrm{E}-12$ & $1.38 \mathrm{E}-12$ & $2.19 \mathrm{E}-12$ & $2.38 \mathrm{E}-12$ & $3.50 \mathrm{E}-12$ \\
\hline V Turning & $8.27 \mathrm{E}-13$ & $1.78 \mathrm{E}-12$ & $1.41 \mathrm{E}-12$ & $2.64 \mathrm{E}-12$ & $2.36 \mathrm{E}-12$ & $4.09 \mathrm{E}-12$ \\
\hline E-W Still & $5.43 \mathrm{E}-13$ & $9.49 \mathrm{E}-13$ & $1.02 \mathrm{E}-12$ & $1.67 \mathrm{E}-12$ & $1.96 \mathrm{E}-12$ & $3.00 \mathrm{E}-12$ \\
\hline E-W Turning & $6.48 \mathrm{E}-13$ & $3.06 \mathrm{E}-12$ & $1.03 \mathrm{E}-12$ & $3.65 \mathrm{E}-12$ & $1.57 \mathrm{E}-12$ & $3.35 \mathrm{E}-12$ \\
\hline N-S Still & $8.58 \mathrm{E}-13$ & $1.40 \mathrm{E}-12$ & $1.43 \mathrm{E}-12$ & $2.30 \mathrm{E}-12$ & $2.28 \mathrm{E}-12$ & $3.38 \mathrm{E}-12$ \\
\hline N-S Turning & $1.02 \mathrm{E}-12$ & $8.86 \mathrm{E}-12$ & $1.85 \mathrm{E}-12$ & $6.98 \mathrm{E}-12$ & $2.57 \mathrm{E}-12$ & $5.62 \mathrm{E}-12$ \\
\hline
\end{tabular}



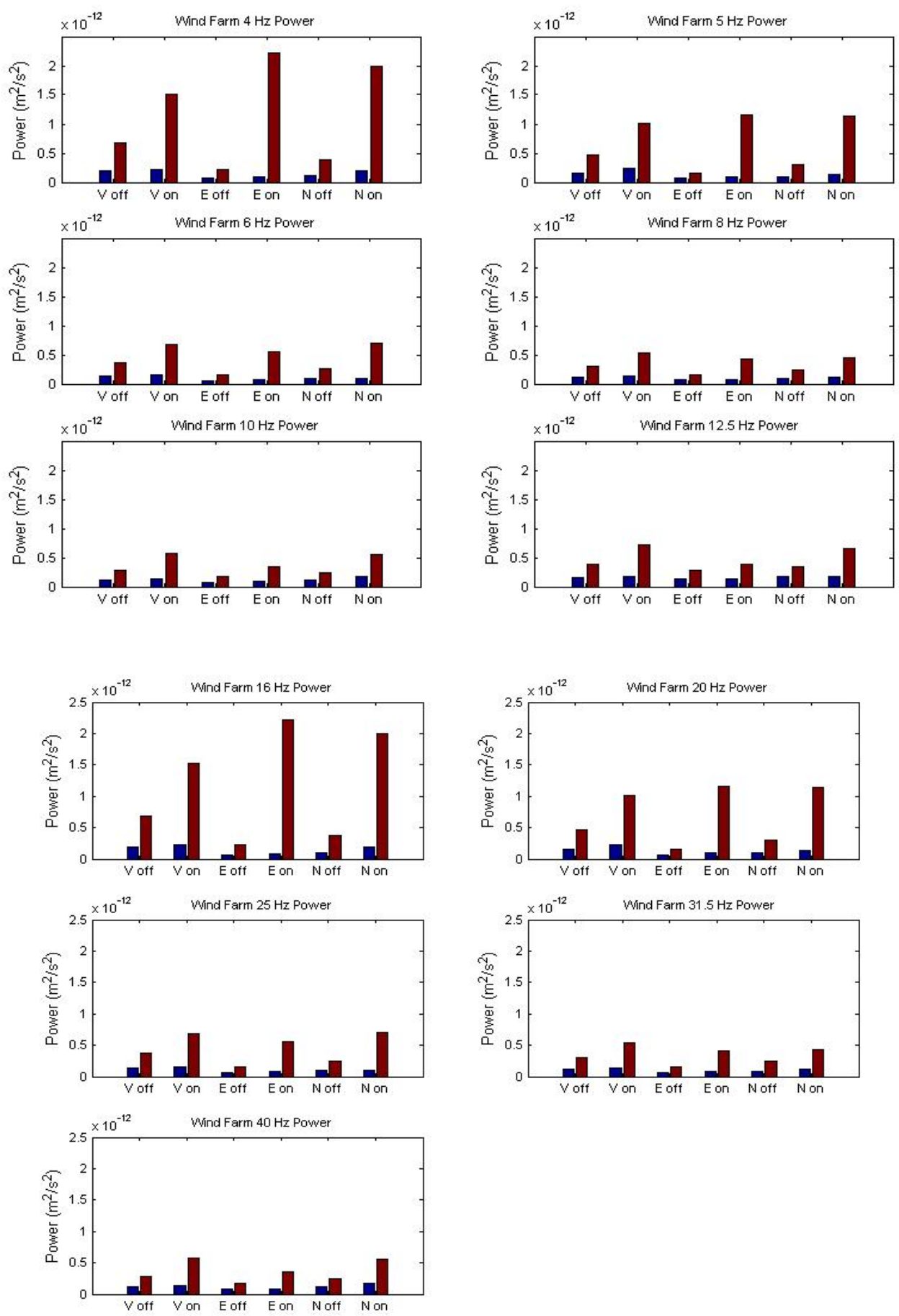

Figure 5. Power range of PDFs of wind farm ground motion by orientation, center frequency, and turbine activity. V, E, and $\mathrm{N}$ denote vertical, east-west, and north-south components of ground motion, respectively. "On" and "off" refer to the turbines turning and still. The blue (red) bar indicates the selected lower (upper) limit of the principal portion of each power PDF.

Of primary interest is the ground motion when the turbine blades are still. Given the remoteness of the wind farm and seismometer sites, other culturally induced seismic noise is negligible. Direct wind loading on the 
ground at the seismometer site is at least partially mitigated by the seismometer being buried, e.g., Sleefe at al. (1999). The separation (5.2 km) between the seismometer location and the wind farm suggests that distant wind-loading of stationary turbines and their support towers is likely not a strong component of the measured ground motion.

When a wind turbine is turning, however, it excites measurable ground motion at distances of at least $6 \mathrm{~km}$ (Styles et al. 2005). The wind-loading of a blade changes while that blade is passing in front of the tower because wind flow is modified by the presence of the tower (van den Berg 2004). A turbine's blade-passing frequency and multiples appear as harmonics in the spectral content of the induced ground motion. Dun Law turbines have a fixed rotation rate of $28.5 \mathrm{rpm}$, which corresponds to a blade-passing frequency of $1.425 \mathrm{~Hz}$. Styles et al. analyzed ground motion as a function of turbine activity and distance from the Dun Law wind farm for frequencies up to $10 \mathrm{~Hz}$, and found that the polarization of the ground motion indicates that blade-passing excitations propagate as Rayleigh waves. The harmonics of the blade passing frequency evident in their data are 2.8, 4.3, $5.7,7.1,8.4$, and $10 \mathrm{~Hz}$, which contribute to the ground motion at center frequencies of 4, 5, 6, 8 and $10 \mathrm{~Hz}$ when the turbines are turning (Figure 5, $\mathrm{V}, \mathrm{N}, \mathrm{E}$ “on").

Blade rotation also generates infrasound. Styles et al. measured infrasound in the vicinity of the Dun Law wind farm with microbarometers. At low wind speeds, infrasound was detectable at a distance of $10 \mathrm{~km}$; but, as average wind speed increased from $4.6 \mathrm{~m} / \mathrm{s}$ to $11.2 \mathrm{~m} / \mathrm{s}$, infrasound eventually was detectable at only $\sim 2 \mathrm{~km}$ from the wind farm. The average wind speed during 0000 - 0050 on 24 September 2004 is high enough $(9.5-11.3 \mathrm{~m} / \mathrm{s})$ that infrasound coupling is not a contributor to the "turbine turning" ground motion analyzed for this report.

\subsection{Enfield}

PDF plots of Enfield vertical ground motion were generated for center frequencies of 4 - $200 \mathrm{~Hz}$ for the hours 0000 - 0800 (0400 - 1200 GMT) on $14 \mathrm{~J}$ uly 2005. Figure 6 is a composite plot of $4-\mathrm{Hz}$ ground motion for the 8-hr period. [Similar PDF plots for the other frequencies are included on the accompanying $\mathrm{CD}$.] Enfield ground motion is notably stronger than ground motion at the wind farm site. Overall, there is a trend of lower (higher) power earlier (later) in the 8-hr period, which would be consistent 
with increasing cultural activity in the vicinity of the site toward morning. In particular, traffic on the town roads on three sides of the site is likely to become more intense (for a rural neighborhood) as people began their Thursday commute to work or perhaps are returning home from work.

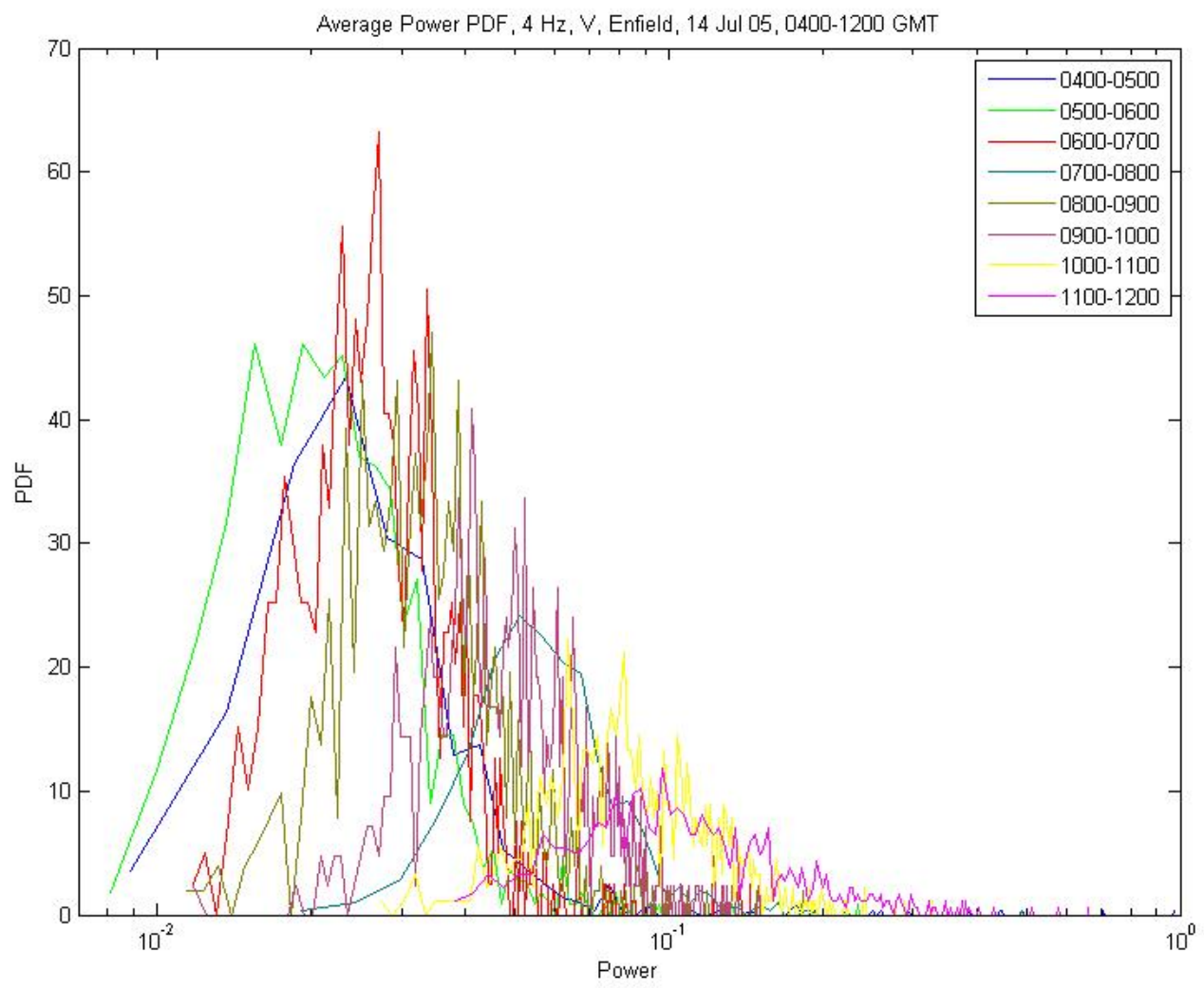

Figure 6. Hourly power PDFs at 4-Hz center frequency for vertical ground motion for the period 0400 - 1200 GMT [0000 - 0800 local time] on 14 July 2005 at the Enfield field site.

Another cause of ground motion at the Enfield site could be the coupling of wind energy, either wind-induced movement of surface objects, such as the trees bounding the field, or directly through turbulent pressures on topographic irregularities. The Enfield geophones were emplaced at the ground surface and so exposed to direct wind coupling. Maximum wind speed during the 8-hr period (Figure 7), however, generally was at or below the threshold for wind noise ( $3-4 \mathrm{~m} / \mathrm{s}$, Table 5) at the surface. Also, the windiest period was within the first $70 \mathrm{~min}$, when ground motion was either weakest or similar to that during subsequent low wind periods. This supports the interpretation that cultural activity, rather than wind loading, is the primary cause of the measured ground motion. 
Wind Speed, Enfield Site, 0000-0800 (local time), 14 July 2005

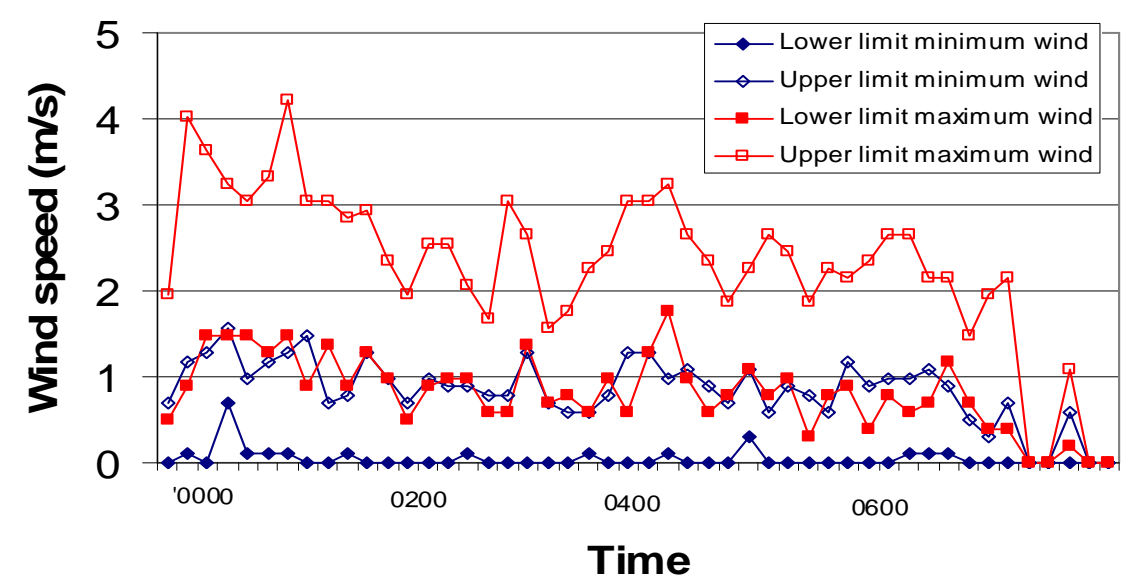

Figure 7. Wind speed data recorded at the Enfield site. Data dropouts occurred during the 10 -min periods beginning 0710, 0720, 0740, and 0750. Maximum, minimum, and average wind speeds were recorded every minute. The values plotted indicate the range in maxima and minima in each 10-min period.

Table 5. Frequency content and wind speed threshold of wind noise (from Peck 2008).

\begin{tabular}{|l|l|l|l|l|}
\hline Study & Location & $\begin{array}{l}\text { Measurement } \\
\text { depth }(\mathrm{m})\end{array}$ & $\begin{array}{l}\text { Frequency range * } \\
(\mathrm{Hz})\end{array}$ & $\begin{array}{l}\text { Wind speed } \\
\text { threshold }(\mathrm{m} / \mathrm{s})\end{array}$ \\
\hline $\begin{array}{l}\text { Withers et al. } \\
1996\end{array}$ & Datil, NM & Surface & $1-60$ & $\sim 3$ \\
\hline $\begin{array}{l}\text { Young et al. } \\
1996\end{array}$ & $\begin{array}{l}\text { Amarillo, TX; } \\
\text { Datil, NM; } \\
\text { Pinedale, WY }\end{array}$ & $0-5$ & $1-60$ & $3-4$ \\
\hline
\end{tabular}

*Instrumentation limited the high-frequency end to $60 \mathrm{~Hz}$.

A power range with each Enfield ground motion PDF was determined by visual inspection of the plots. The upper and lower limits of the power range are not the extreme limits of the PDF; rather, they are a subjective determination of the principal portion of a PDF range, excluding low amplitude oscillatory tails. The selected limits were tabulated for each center frequency (Table 6 - 9) and plotted (Figure 8). 
Table 6. Lower and upper limits of the principal portion of Enfield power PDFs by center frequency $(4-10 \mathrm{~Hz})$ and hour. Vertical ground motion. Units: $\mathrm{m}^{2} / \mathrm{s}^{2}$.

\begin{tabular}{|l|l|l|l|l|l|l|l|l|l|l|}
\hline \multirow{2}{*}{$\begin{array}{l}\text { Hour } \\
\text { (GMT) }\end{array}$} & \multicolumn{2}{|c|}{$4 \mathrm{~Hz}$} & \multicolumn{3}{c|}{$5 \mathrm{~Hz}$} & \multicolumn{3}{c|}{$6 \mathrm{~Hz}$} & \multicolumn{2}{c|}{$8 \mathrm{~Hz}$} \\
\cline { 2 - 11 } & Limit & $\begin{array}{l}\text { Upper } \\
\text { Limit }\end{array}$ & $\begin{array}{l}\text { Lower } \\
\text { Limit }\end{array}$ & $\begin{array}{l}\text { Upper } \\
\text { Limit }\end{array}$ & $\begin{array}{l}\text { Lower } \\
\text { Limit }\end{array}$ & $\begin{array}{l}\text { Upper } \\
\text { Limit }\end{array}$ & $\begin{array}{l}\text { Lower } \\
\text { Limit }\end{array}$ & $\begin{array}{l}\text { Upper } \\
\text { Limit }\end{array}$ & $\begin{array}{l}\text { Lower } \\
\text { Limit }\end{array}$ & $\begin{array}{l}\text { Upper } \\
\text { Limit }\end{array}$ \\
\hline 400 & 0.008829 & 0.07161 & 0.01319 & 0.1065 & 0.0137 & 0.3646 & 0.01613 & 0.1724 & 0.008032 & 0.04341 \\
\hline 500 & 0.008119 & 0.05456 & 0.01446 & 0.06447 & 0.0128 & 0.05943 & 0.01567 & 0.05915 & 0.007604 & 0.02509 \\
\hline 600 & 0.01309 & 0.04825 & 0.01673 & 0.06333 & 0.01723 & 0.06647 & 0.01894 & 0.05987 & 0.01193 & 0.02707 \\
\hline 700 & 0.02448 & 0.126 & 0.03214 & 0.196 & 0.041 & 0.1628 & 0.04363 & 0.1413 & 0.02135 & 0.06494 \\
\hline 800 & 0.01825 & 0.06359 & 0.01586 & 0.09393 & 0.01628 & 0.1039 & 0.02059 & 0.1212 & 0.01212 & 0.03965 \\
\hline 900 & 0.02361 & 0.08912 & 0.0244 & 0.1094 & 0.02613 & 0.1415 & 0.04075 & 0.1751 & 0.02148 & 0.09556 \\
\hline 1000 & 0.04091 & 0.1583 & 0.05352 & 0.224 & 0.06666 & 0.2555 & 0.08889 & 0.4634 & 0.07341 & 0.4727 \\
\hline 1100 & 0.03812 & 0.2191 & 0.05513 & 0.2725 & 0.07105 & 0.3442 & 0.102 & 0.7248 & 0.09147 & 0.6637 \\
\hline
\end{tabular}

Table 7. Lower and upper limits of the principal portion of Enfield power PDFs by center frequency $(12.5-31.5 \mathrm{~Hz})$ and hour. Vertical ground motion. Units: $\mathrm{m}^{2} / \mathrm{s}^{2}$.

\begin{tabular}{|c|c|c|c|c|c|c|c|c|c|c|}
\hline \multirow[b]{2}{*}{$\begin{array}{l}\text { Hour } \\
\text { (GMT) }\end{array}$} & \multicolumn{2}{|c|}{$12.5 \mathrm{~Hz}$} & \multicolumn{2}{|c|}{$16 \mathrm{~Hz}$} & \multicolumn{2}{|c|}{$20 \mathrm{~Hz}$} & \multicolumn{2}{|c|}{$25 \mathrm{~Hz}$} & \multicolumn{2}{|c|}{$31.5 \mathrm{~Hz}$} \\
\hline & Lower Limit & $\begin{array}{l}\text { Upper } \\
\text { Limit }\end{array}$ & Lower Limit & $\begin{array}{l}\text { Upper } \\
\text { Limit }\end{array}$ & Lower Limit & Upper Limit & Lower Limit & Upper Limit & Lower Limit & Upper Limit \\
\hline 400 & 0.004316 & 0.05579 & 0.0529 & 0.1011 & 0.004263 & 0.04829 & 0.003725 & 0.05381 & 0.003471 & 0.03766 \\
\hline 500 & 0.004192 & 0.0127 & 0.002972 & 0.01076 & 0.002993 & 0.01049 & 0.002316 & 0.009676 & 0.00283 & 0.008811 \\
\hline 600 & 0.005407 & 0.0127 & 0.003941 & 0.01046 & 0.004617 & 0.009006 & 0.002895 & 0.006481 & 0.111 & 0.1615 \\
\hline 700 & 0.01091 & 0.02864 & 0.009596 & 0.02174 & 0.0101 & 0.02787 & 0.006536 & 0.02225 & 0.1668 & 0.2801 \\
\hline 800 & 0.006296 & 0.0255 & 0.004991 & 0.01605 & 0.005806 & 0.01677 & 0.003825 & 0.01451 & 0.003717 & 0.01161 \\
\hline 900 & 0.01254 & 0.05873 & 0.007504 & 0.02929 & 0.007933 & 0.0282 & 0.005337 & 0.02057 & 0.005429 & 0.02029 \\
\hline 1000 & 0.03044 & 0.4077 & 0.02624 & 0.3116 & 0.018 & 0.2196 & 0.01193 & 0.1916 & 0.3816 & 0.5714 \\
\hline 1100 & 0.03797 & 1.221 & 0.02794 & 0.8805 & 0.02337 & 1.438 & 0.02051 & 0.6963 & 0.1248 & 0.857 \\
\hline
\end{tabular}


Table 8. Lower and upper limits of the principal portion of Enfield power PDFs by center frequency $(40-100 \mathrm{~Hz})$ and hour. Vertical ground motion. Units: $\mathrm{m}^{2} / \mathrm{s}^{2}$.

\begin{tabular}{|l|l|l|l|l|l|l|l|l|l|l|}
\hline \multirow{2}{*}{$\begin{array}{l}\text { Hour } \\
\text { (GMT) }\end{array}$} & \multicolumn{2}{|c|}{$40 \mathrm{~Hz}$} & \multicolumn{2}{c|}{$50 \mathrm{~Hz}$} & \multicolumn{3}{c|}{$63 \mathrm{~Hz}$} & \multicolumn{3}{c|}{$80 \mathrm{~Hz}$} \\
\cline { 2 - 12 } & Limit & $\begin{array}{l}\text { Upper } \\
\text { Limit }\end{array}$ & $\begin{array}{l}\text { Lower } \\
\text { Limit }\end{array}$ & $\begin{array}{l}\text { Upper } \\
\text { Limit }\end{array}$ & $\begin{array}{l}\text { Lower } \\
\text { Limit }\end{array}$ & $\begin{array}{l}\text { Upper } \\
\text { Limit }\end{array}$ & $\begin{array}{l}\text { Lower } \\
\text { Limit }\end{array}$ & $\begin{array}{l}\text { Upper } \\
\text { Limit }\end{array}$ & $\begin{array}{l}\text { Lower } \\
\text { Limit }\end{array}$ & $\begin{array}{l}\text { Upper } \\
\text { Limit }\end{array}$ \\
\hline 400 & 0.003957 & 0.04532 & 0.003741 & 0.04009 & 0.6926 & 0.9114 & 0.03949 & 0.2929 & 0.07384 & 0.6782 \\
\hline 500 & 0.002575 & 0.0111 & 0.00227 & 0.01017 & 0.6647 & 0.7668 & 0.01795 & 0.1107 & 0.03231 & 0.4741 \\
\hline 600 & 0.002863 & 0.006205 & 0.002704 & 0.00622 & 1.032 & 1.139 & 0.0218 & 0.0767 & 0.04164 & 0.2763 \\
\hline 700 & 0.005742 & 0.0437 & 0.005959 & 0.0302 & 2.284 & 2.478 & 0.04279 & 0.2083 & 0.08324 & 0.521 \\
\hline 800 & 0.004702 & 0.03254 & 0.003702 & 0.01965 & 0.9441 & 1.039 & 0.02849 & 0.1293 & 0.05305 & 0.4529 \\
\hline 900 & 0.006781 & 0.0306 & 0.009056 & 0.02855 & 0.9279 & 1.252 & 0.08609 & 0.3454 & 0.0842 & 0.5941 \\
\hline 1000 & 0.03225 & 0.1947 & 0.03134 & 0.2195 & 0.1848 & 0.514 & 0.3151 & 1.1 & 0.1033 & 0.4985 \\
\hline 1100 & 0.06029 & 1.469 & 0.04451 & 0.4025 & 0.1069 & 0.7561 & 0.307 & 2.838 & 0.07222 & 0.5024 \\
\hline
\end{tabular}

Table 9. Lower and upper limits of the principal portion of Enfield power PDFs by center frequency $(125-200 \mathrm{~Hz})$ and hour. Vertical ground motion. Units: $\mathrm{m}^{2} / \mathrm{s}^{2}$.

\begin{tabular}{|l|l|l|l|l|l|l|}
\hline \multirow{2}{*}{$\begin{array}{l}\text { Hour } \\
\text { (GMT) }\end{array}$} & \multicolumn{2}{|c|}{$125 \mathrm{~Hz}$} & \multicolumn{2}{c|}{$160 \mathrm{~Hz}$} & \multicolumn{2}{c|}{$200 \mathrm{~Hz}$} \\
\cline { 2 - 7 } & $\begin{array}{l}\text { Limit } \\
400\end{array}$ & $\begin{array}{l}\text { Upper } \\
\text { Limit }\end{array}$ & $\begin{array}{l}\text { Lower } \\
\text { Limit }\end{array}$ & $\begin{array}{l}\text { Upper } \\
\text { Limit }\end{array}$ & $\begin{array}{l}\text { Lower } \\
\text { Limit }\end{array}$ & $\begin{array}{l}\text { Upper } \\
\text { Limit }\end{array}$ \\
\hline 500 & 0.07036 & 1.608 & 0.09305 & 1.276 & 0.04713 & 0.3591 \\
\hline 600 & 0.07645 & 0.537 & 0.07089 & 0.38 & 0.03019 & 0.183 \\
\hline 700 & 0.1363 & 0.8658 & 0.1196 & 0.749 & 0.06097 & 0.2609 \\
\hline 800 & 0.08071 & 0.8508 & 0.06441 & 0.649 & 0.03328 & 0.2605 \\
\hline 900 & 0.133 & 1.258 & 0.1139 & 0.7238 & 0.05339 & 0.2891 \\
\hline 1000 & 0.1523 & 0.9507 & 0.1305 & 0.711 & 0.06405 & 0.323 \\
\hline 1100 & 0.09935 & 1.757 & 0.09146 & 0.3993 & 0.04155 & 0.2374 \\
\hline
\end{tabular}



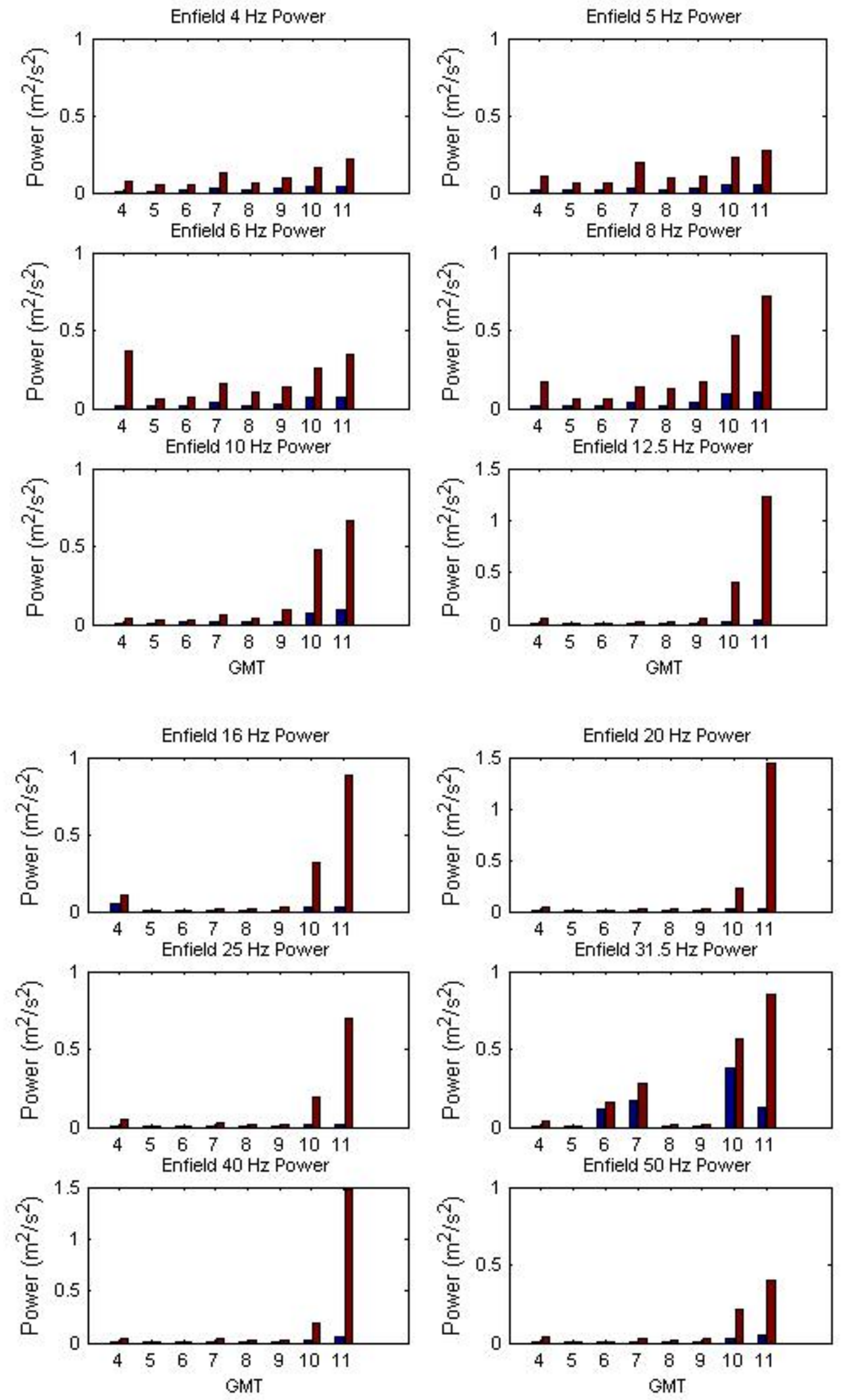

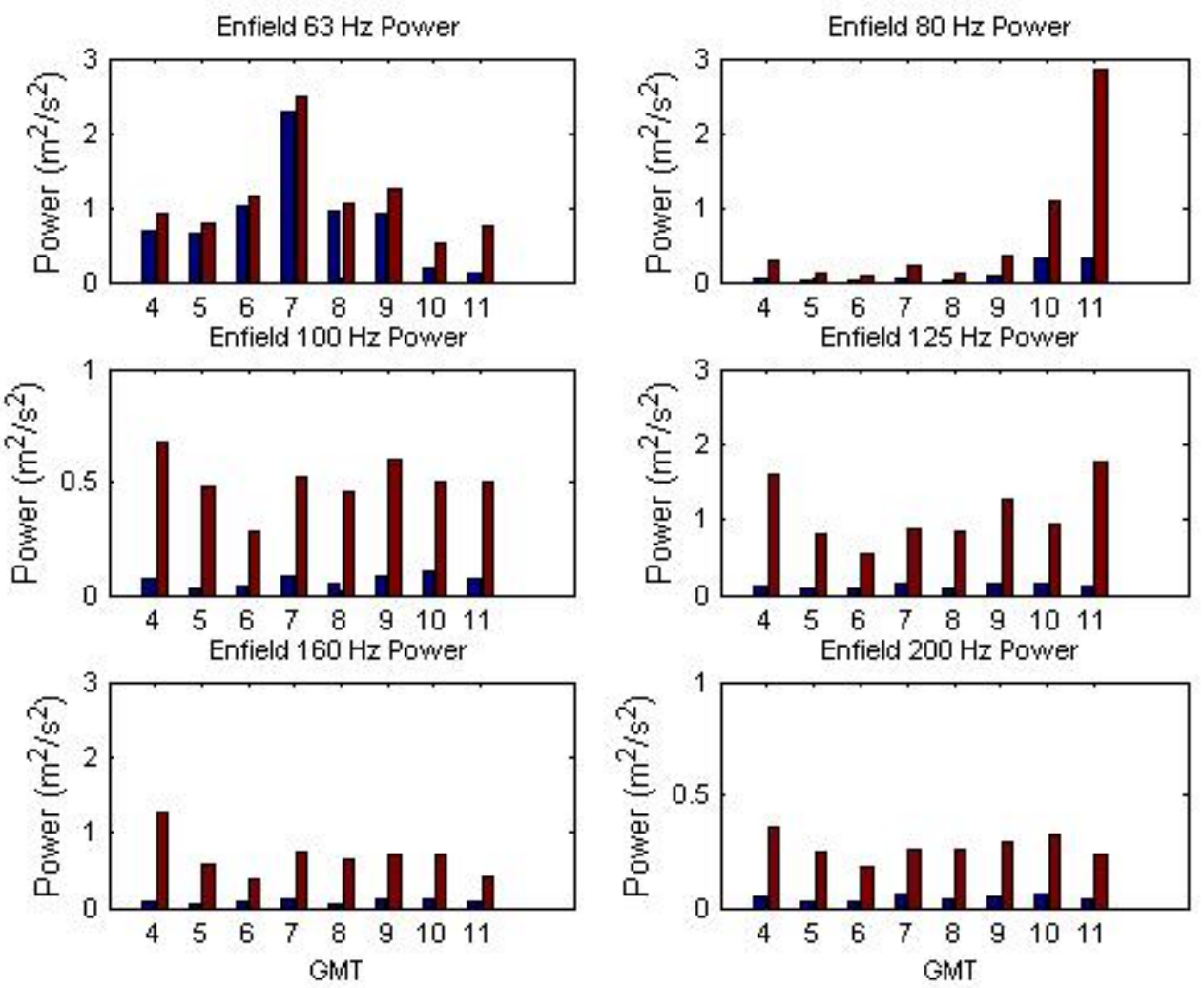

Figure 8. Power range of PDFs of Enfield ground motion by center frequency and hour. The blue (red) bar indicates the selected lower (upper) limit of the principal portion of each power PDF. The $x$ axis identifies the hourly average PDF represented: $0400-1100 \mathrm{hr}$ GMT, or 0000

- $0700 \mathrm{hr}$ local time. The Y-axis upper limit is $1,1.5$ or 3 , depending on center frequency.

Interesting features in the 63-Hz power PDF (Figure 8) are the $0700 \mathrm{hr}$ GMT (0400 hr local time) peak and the reduced power levels for the 1000 and $1100 \mathrm{hr}$. Any 60-Hz noise caused by power line pickup would be included in this center frequency; variation in power use would contribute to the time-dependence evident with the 63-Hz PDFs. It is not clear, however, why this would peak during the $0700 \mathrm{hr}$ GMT and be lower in subsequent hours (1000,1100), when nearby households are likely to be more active and the power draw for household lights and appliances (water heater, stove, and so on) correspondingly would be greater. The $0700 \mathrm{hr}$ GMT peak is also evident in the 31.5-Hz power PDF, which includes $30-\mathrm{Hz}$ noise that could be generated by running motors such as refrigerators. The land owner, however, is not aware of any equipment that would have been operating at $0700 \mathrm{GMT}$. The 31.5- Hz frequency band is stronger by a factor of two during 1000 and $1100 \mathrm{hr}$ GMT, which is consistent with increased use of appliances, water pumps, and so on during that time block. 
Ground motion is stronger in the $0400 \mathrm{hr}$ than in the 0500 and $0600 \mathrm{hr}$ (GMT) at all frequency bands except $31.5 \mathrm{~Hz}$ and $63 \mathrm{~Hz}$, suggesting that local cultural activity, as a source of ground motion, changes significantly either in nature or intensity between the 0400 and $0500 \mathrm{hr}$. Other than the $0400 \mathrm{hr}$ peak, high-frequency ground motion ( 100 - $200 \mathrm{~Hz}$ center frequencies) does not display a systematic dependence on time of day.

Low-frequency ground motion ( $\leq 80 \mathrm{~Hz}$, other than $63 \mathrm{~Hz}$ ) is strongest in the 1000 and $1100 \mathrm{hr}$ GMT, which is consistent with the expectation of increased cultural activity, including traffic, during those hours.

\subsection{Highway}

PDF plots of highway ground motion by hour were generated for center frequencies of 4 to $80 \mathrm{~Hz}$. Ground motion is analyzed for its variation by orientation, by day of the week, and by time of day.

\subsubsection{Hourly variation in vertical ground motion}

The variation in vertical ground motion over $24 \mathrm{hr}$ is shown with $4-\mathrm{Hz}$ PDFs for Wednesday, 15 February 2006 and Sunday, 19 February 2006 (Figure 9). [Similar PDF plots for the other frequencies are included on the accompanying $\mathrm{CD}$.] On both days there is clear differentiation between weaker ground motion during nighttime (PDFs in blues and greens) and stronger ground motion during daytime (PDFs in reds and oranges), with the daytime/ nighttime difference in power more pronounced on Sunday. 

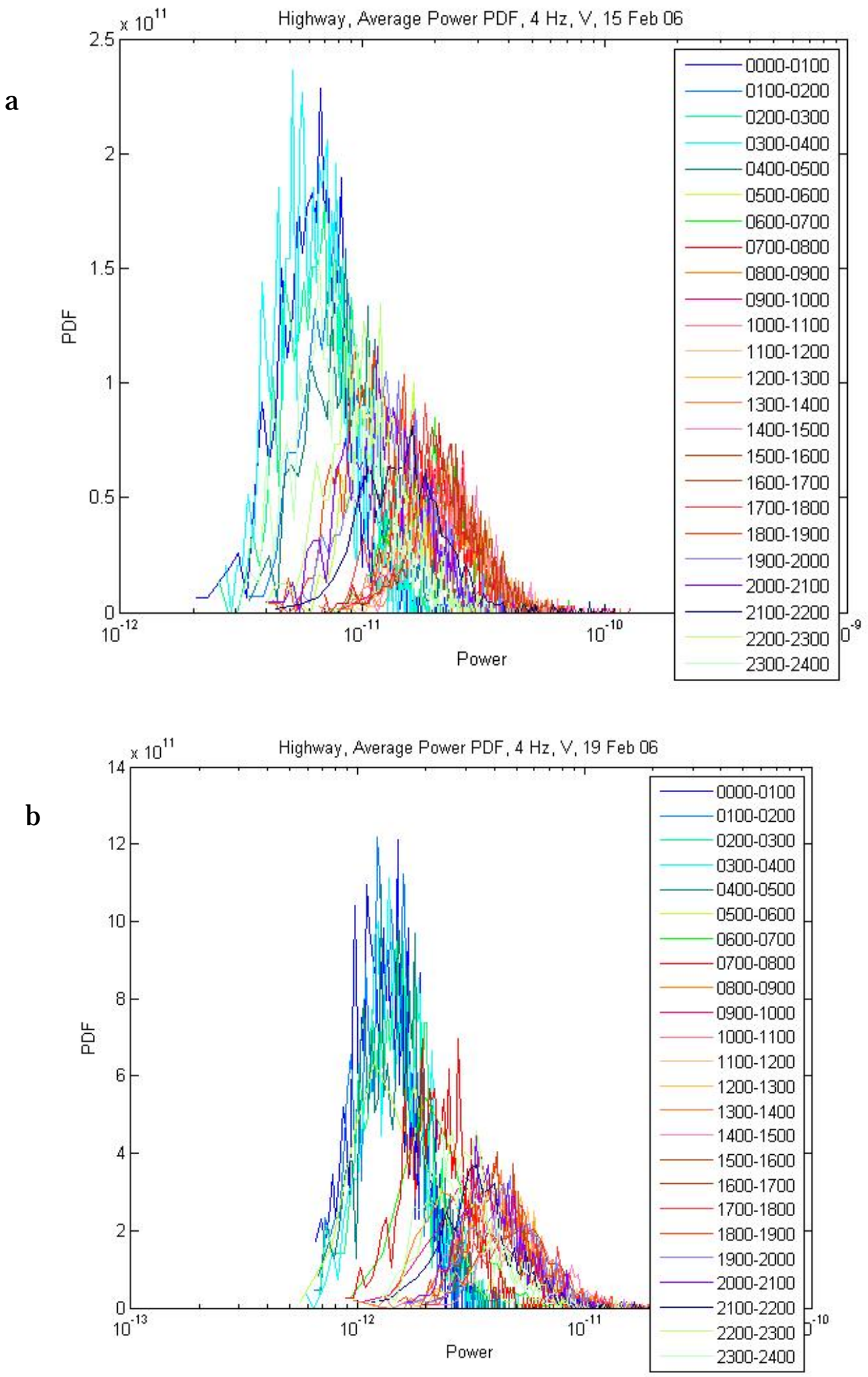

Figure 9. Hourly power PDFs at 4- $\mathrm{Hz}$ center frequency for vertical ground motion at the highway site on (a) Wednesday, 15 February 2006 and (b) Sunday, 19 February 2006. The PDFs are color coded with blues and greens for nighttime hours (1900 - 0600) and reds and oranges for daytime hours $(0700-1800)$. 
A power range with each hour's PDF on 15 February and 19 February was determined by visual inspection of the plots. The upper and lower limits of the power range are not the extreme limits of the PDF; rather, they are a subjective determination of the principal portion of a PDF range, excluding low amplitude oscillatory tails. The selected limits were tabulated for each center frequency (Tables 10 - 12 for 15 February, Tables 13 - 15 for 19 February) and plotted (Figure 10, 11). On both days, a daytime/ nighttime difference in vertical ground motion is evident at frequencies of 4 to 12.5 $\mathrm{Hz}$. At $16 \mathrm{~Hz}$, strong daytime ground motion is distinguishable only for 1100 through $1400 \mathrm{hr}$. At higher frequencies, the daytime/ nighttime difference largely is absent, as midday ground motion overall is comparable to that during the $0000 \mathrm{hr}$. Instead, ground motion at the higher frequencies is variable on an hourly basis. Ground motion on Sunday is notably weaker at each center frequency.

Table 10. Lower and upper limits of the principal portion of highway power PDFs by center frequency (4 Hz - $10 \mathrm{~Hz}$ ) and hour for Wednesday, 15 February 2006. Vertical ground motion. Units: $\mathrm{m}^{2} / \mathrm{s}^{2}$.

\begin{tabular}{|c|c|c|c|c|c|c|c|c|c|c|}
\hline \multirow[b]{2}{*}{ Hour } & \multicolumn{2}{|c|}{$4 \mathrm{~Hz}$} & \multicolumn{2}{|c|}{$5 \mathrm{~Hz}$} & \multicolumn{2}{|c|}{$6 \mathrm{~Hz}$} & \multicolumn{2}{|c|}{$8 \mathrm{~Hz}$} & \multicolumn{2}{|c|}{$10 \mathrm{~Hz}$} \\
\hline & $\begin{array}{l}\text { Lower } \\
\text { Limit }\end{array}$ & $\begin{array}{l}\text { Upper } \\
\text { Limit }\end{array}$ & $\begin{array}{l}\text { Lower } \\
\text { Limit }\end{array}$ & $\begin{array}{l}\text { Upper } \\
\text { Limit }\end{array}$ & $\begin{array}{l}\text { Lower } \\
\text { Limit }\end{array}$ & $\begin{array}{l}\text { Upper } \\
\text { Limit }\end{array}$ & $\begin{array}{l}\text { Lower } \\
\text { Limit }\end{array}$ & $\begin{array}{l}\text { Upper } \\
\text { Limit }\end{array}$ & $\begin{array}{l}\text { Lower } \\
\text { Limit }\end{array}$ & $\begin{array}{l}\text { Upper } \\
\text { Limit }\end{array}$ \\
\hline 0 & 3.33E-12 & 1.08E-11 & 3.75E-12 & $1.08 \mathrm{E}-11$ & $5.78 \mathrm{E}-12$ & $1.38 \mathrm{E}-11$ & $7.22 \mathrm{E}-12$ & 2.32E-11 & 7.17E-12 & 1.93E-11 \\
\hline 100 & 3.91E-12 & 1.50E-11 & 3.66E-12 & $1.37 \mathrm{E}-11$ & 5.23E-12 & $1.80 \mathrm{E}-11$ & 8.99E-12 & $2.19 \mathrm{E}-11$ & 7.58E-12 & 2.33E-11 \\
\hline 200 & 3.27E-12 & 1.38E-11 & 3.39E-12 & $1.12 \mathrm{E}-11$ & 4.92E-12 & $1.59 \mathrm{E}-11$ & $6.01 \mathrm{E}-12$ & 2.03E-11 & $7.72 \mathrm{E}-12$ & 1.93E-11 \\
\hline 300 & 3.04E-12 & 1.02E-11 & $3.47 \mathrm{E}-12$ & $1.13 \mathrm{E}-11$ & $5.29 \mathrm{E}-12$ & $1.27 \mathrm{E}-11$ & $6.19 \mathrm{E}-12$ & $2.44 \mathrm{E}-11$ & $6.95 \mathrm{E}-12$ & 2.38E-11 \\
\hline 400 & 4.42E-12 & 1.60E-11 & 3.79E-12 & $1.64 \mathrm{E}-11$ & 5.70E-12 & $1.61 \mathrm{E}-11$ & 8.02E-12 & $2.99 \mathrm{E}-11$ & $9.20 \mathrm{E}-12$ & 2.27E-11 \\
\hline 500 & 6.13E-12 & 2.23E-11 & 6.85E-12 & 2.09E-11 & 8.94E-12 & $2.52 \mathrm{E}-11$ & 1.50E-01 & 3.83E-11 & $1.35 \mathrm{E}-11$ & 3.38E-11 \\
\hline 600 & $9.71 \mathrm{E}-12$ & 3.13E-11 & $9.27 \mathrm{E}-12$ & 2.83E-11 & 1.19E-11 & 3.25E-11 & 2.00E-11 & $5.18 \mathrm{E}-11$ & $1.88 \mathrm{E}-11$ & 4.60E-11 \\
\hline 700 & 1.04E-11 & 3.10E-11 & 1.08E-11 & 2.91E-11 & 1.23E-11 & 2.95E-11 & $1.76 \mathrm{E}-11$ & $4.24 \mathrm{E}-11$ & 2.07E-11 & 4.03E-11 \\
\hline 800 & 8.99E-12 & 4.05E-11 & 1.04E-11 & 3.21E-11 & $8.74 \mathrm{E}-12$ & 2.95E-11 & $1.03 \mathrm{E}-11$ & $2.71 \mathrm{E}-11$ & 1.64E-11 & 3.97E-11 \\
\hline 900 & $9.47 \mathrm{E}-12$ & 3.90E-11 & $1.12 \mathrm{E}-11$ & 3.84E-11 & $1.50 \mathrm{E}-11$ & 3.43E-11 & $1.81 \mathrm{E}-11$ & $4.29 \mathrm{E}-11$ & $2.18 \mathrm{E}-11$ & 4.67E-11 \\
\hline 1000 & 1.30E-11 & 3.54E-11 & 1.18E-11 & 4.10E-11 & $1.55 \mathrm{E}-01$ & 3.63E-11 & $2.27 \mathrm{E}-11$ & $5.25 \mathrm{E}-11$ & $1.87 \mathrm{E}-11$ & 4.62E-11 \\
\hline 1100 & 1.09E-11 & 4.21E-11 & $9.75 \mathrm{E}-12$ & 3.80E-11 & $1.38 \mathrm{E}-11$ & 3.51E-11 & $1.99 \mathrm{E}-11$ & 5.53E-11 & $1.89 \mathrm{E}-11$ & $4.75 \mathrm{E}-11$ \\
\hline 1200 & 1.18E-11 & 3.36E-11 & 1.15E-11 & 3.65E-11 & 1.26E-11 & 4.15E-11 & 2.03E-11 & $5.50 \mathrm{E}-11$ & $1.87 \mathrm{E}-11$ & $4.02 \mathrm{E}-11$ \\
\hline 1300 & 1.22E-11 & 3.66E-11 & 1.12E-11 & 4.21E-11 & 1.33E-11 & 3.56E-11 & $2.54 \mathrm{E}-11$ & $5.50 \mathrm{E}-11$ & 2.14E-11 & $4.82 \mathrm{E}-11$ \\
\hline 1400 & 1.21E-11 & 4.03E-11 & $1.18 \mathrm{E}-11$ & 3.83E-11 & $1.56 \mathrm{E}-11$ & 3.54E-11 & $2.49 \mathrm{E}-11$ & $5.22 \mathrm{E}-11$ & $2.58 \mathrm{E}-11$ & $4.72 \mathrm{E}-11$ \\
\hline 1500 & 1.13E-11 & 3.97E-11 & $9.34 \mathrm{E}-12$ & 3.73E-11 & 1.19E-11 & 3.28E-11 & $1.63 \mathrm{E}-11$ & $5.09 \mathrm{E}-11$ & 1.76E-11 & $4.23 \mathrm{E}-11$ \\
\hline 1600 & 1.38E-11 & 3.16E-11 & 9.98E-12 & 2.90E-11 & 1.06E-11 & $2.42 \mathrm{E}-11$ & $1.39 \mathrm{E}-11$ & 4.19E-11 & $1.24 \mathrm{E}-11$ & $3.52 \mathrm{E}-11$ \\
\hline 1700 & 8.78E-12 & $2.70 \mathrm{E}-11$ & 1.04E-11 & 4.07E-11 & $1.22 \mathrm{E}-11$ & $3.25 \mathrm{E}-11$ & $1.52 \mathrm{E}-11$ & $4.28 \mathrm{E}-11$ & 1.71E-11 & $4.22 \mathrm{E}-11$ \\
\hline 1800 & 5.97E-12 & 2.12E-11 & 6.83E-12 & 2.27E-11 & $9.83 \mathrm{E}-12$ & $2.48 \mathrm{E}-11$ & $1.30 \mathrm{E}-11$ & 3.65E-11 & $1.36 \mathrm{E}-11$ & 3.38E-11 \\
\hline 1900 & $6.44 \mathrm{E}-12$ & 2.40E-11 & $6.95 \mathrm{E}-12$ & $1.92 \mathrm{E}-11$ & 8.80E-12 & $2.23 \mathrm{E}-11$ & $1.40 \mathrm{E}-11$ & 3.58E-11 & 1.29E-11 & 3.18E-11 \\
\hline
\end{tabular}




\begin{tabular}{|l|l|l|l|l|l|l|l|l|l|l|l|}
\hline \multirow{2}{*}{ Hour } & \multicolumn{2}{|c|}{$4 \mathrm{~Hz}$} & \multicolumn{2}{c|}{$5 \mathrm{~Hz}$} & \multicolumn{2}{c|}{$6 \mathrm{~Hz}$} & \multicolumn{3}{c|}{$8 \mathrm{~Hz}$} & \multicolumn{2}{c|}{$10 \mathrm{~Hz}$} \\
\cline { 2 - 12 } & $\begin{array}{l}\text { Lower } \\
\text { Limit }\end{array}$ & $\begin{array}{l}\text { Upper } \\
\text { Limit }\end{array}$ & $\begin{array}{l}\text { Lower } \\
\text { Limit }\end{array}$ & $\begin{array}{l}\text { Upper } \\
\text { Limit }\end{array}$ & $\begin{array}{l}\text { Lower } \\
\text { Limit }\end{array}$ & $\begin{array}{l}\text { Upper } \\
\text { Limit }\end{array}$ & $\begin{array}{l}\text { Lower } \\
\text { Limit }\end{array}$ & $\begin{array}{l}\text { Upper } \\
\text { Limit }\end{array}$ & $\begin{array}{l}\text { Lower } \\
\text { Limit }\end{array}$ & $\begin{array}{l}\text { Upper } \\
\text { Limit }\end{array}$ \\
\hline 2000 & $7.04 \mathrm{E}-12$ & $2.32 \mathrm{E}-11$ & $7.01 \mathrm{E}-12$ & $2.00 \mathrm{E}-11$ & $7.22 \mathrm{E}-12$ & $2.28 \mathrm{E}-11$ & $1.44 \mathrm{E}-11$ & $3.70 \mathrm{E}-11$ & $1.21 \mathrm{E}-11$ & $3.04 \mathrm{E}-11$ \\
\hline 2100 & $6.51 \mathrm{E}-12$ & $2.86 \mathrm{E}-11$ & $6.27 \mathrm{E}-12$ & $2.03 \mathrm{E}-11$ & $6.92 \mathrm{E}-12$ & $1.91 \mathrm{E}-11$ & $1.08 \mathrm{E}-11$ & $3.20 \mathrm{E}-11$ & $1.04 \mathrm{E}-11$ & $2.80 \mathrm{E}-11$ \\
\hline 2200 & $5.22 \mathrm{E}-12$ & $1.88 \mathrm{E}-11$ & $4.60 \mathrm{E}-12$ & $1.76 \mathrm{E}-11$ & $7.05 \mathrm{E}-12$ & $1.76 \mathrm{E}-11$ & $9.73 \mathrm{E}-12$ & $2.94 \mathrm{E}-11$ & $9.73 \mathrm{E}-12$ & $2.46 \mathrm{E}-11$ \\
\hline 2300 & $3.73 \mathrm{E}-12$ & $1.62 \mathrm{E}-11$ & $5.14 \mathrm{E}-12$ & $1.35 \mathrm{E}-01$ & $5.88 \mathrm{E}-12$ & $1.59 \mathrm{E}-11$ & $9.57 \mathrm{E}-12$ & $2.49 \mathrm{E}-11$ & $7.68 \mathrm{E}-12$ & $2.25 \mathrm{E}-11$ \\
\hline
\end{tabular}


Table 11. Lower and upper limits of the principal portion of highway power PDFs by center frequency $(12.5 \mathrm{~Hz}-31.5 \mathrm{~Hz})$ and hour for Wednesday, 15 February 2006. Vertical ground motion. Units: $\mathrm{m}^{2} / \mathrm{s}^{2}$.

\begin{tabular}{|c|c|c|c|c|c|c|c|c|c|c|}
\hline \multirow[b]{2}{*}{ Hour } & \multicolumn{2}{|c|}{$12.5 \mathrm{~Hz}$} & \multicolumn{2}{|c|}{$16 \mathrm{~Hz}$} & \multicolumn{2}{|c|}{$20 \mathrm{~Hz}$} & \multicolumn{2}{|c|}{$25 \mathrm{~Hz}$} & \multicolumn{2}{|c|}{$31.5 \mathrm{~Hz}$} \\
\hline & $\begin{array}{l}\text { Lower } \\
\text { Limit }\end{array}$ & $\begin{array}{l}\text { Upper } \\
\text { Limit }\end{array}$ & $\begin{array}{l}\text { Lower } \\
\text { Limit }\end{array}$ & $\begin{array}{l}\text { Upper } \\
\text { Limit }\end{array}$ & $\begin{array}{l}\text { Lower } \\
\text { Limit }\end{array}$ & $\begin{array}{l}\text { Upper } \\
\text { Limit }\end{array}$ & $\begin{array}{l}\text { Lower } \\
\text { Limit }\end{array}$ & $\begin{array}{l}\text { Upper } \\
\text { Limit }\end{array}$ & $\begin{array}{l}\text { Lower } \\
\text { Limit }\end{array}$ & $\begin{array}{l}\text { Upper } \\
\text { Limit }\end{array}$ \\
\hline 0 & 1.30E-11 & 3.16E-11 & 4.83E-11 & $1.11 \mathrm{E}-10$ & $2.21 \mathrm{E}-10$ & 4.84E-10 & $1.34 \mathrm{E}-10$ & 3.08E-10 & $1.94 \mathrm{E}-10$ & 4.43E-10 \\
\hline 100 & $1.34 \mathrm{E}-11$ & 3.30E-11 & 5.03E-11 & $1.37 \mathrm{E}-10$ & 2.16E-10 & 5.02E-10 & 1.39E-10 & $2.74 \mathrm{E}-10$ & 2.07E-10 & 4.29E-10 \\
\hline 200 & $1.21 \mathrm{E}-11$ & $2.88 \mathrm{E}-11$ & 4.27E-11 & $1.10 \mathrm{E}-10$ & 1.86E-10 & 3.96E-10 & $1.15 \mathrm{E}-10$ & 2.39E-10 & 1.79E-10 & 3.34E-10 \\
\hline 300 & $1.12 \mathrm{E}-11$ & 2.39E-11 & 3.45E-11 & $9.05 \mathrm{E}-11$ & $1.33 \mathrm{E}-10$ & 3.15E-10 & 8.05E-11 & $1.73 \mathrm{E}-10$ & 1.17E-10 & $2.83 \mathrm{E}-10$ \\
\hline 400 & $1.21 \mathrm{E}-11$ & $2.98 \mathrm{E}-11$ & 3.84E-11 & $8.32 \mathrm{E}-11$ & $1.05 \mathrm{E}-10$ & $2.57 \mathrm{E}-10$ & $6.41 \mathrm{E}-11$ & $1.37 \mathrm{E}-10$ & $9.69 \mathrm{E}-11$ & $1.92 \mathrm{E}-10$ \\
\hline 500 & 1.89E-11 & 3.81E-11 & 4.17E-11 & $1.02 \mathrm{E}-10$ & $1.37 \mathrm{E}-10$ & 2.99E-10 & 6.90E-11 & $1.66 \mathrm{E}-10$ & $1.23 \mathrm{E}-10$ & 2.61E-10 \\
\hline 600 & $2.18 \mathrm{E}-11$ & 4.47E-11 & 5.97E-11 & $1.16 \mathrm{E}-10$ & $1.81 \mathrm{E}-10$ & $3.41 \mathrm{E}-10$ & 8.63E-11 & $1.70 \mathrm{E}-10$ & $1.54 \mathrm{E}-10$ & $2.84 \mathrm{E}-10$ \\
\hline 700 & $2.27 \mathrm{E}-11$ & 4.10E-11 & 5.15E-11 & $1.13 \mathrm{E}-10$ & $1.81 \mathrm{E}-10$ & 3.34E-10 & $9.42 \mathrm{E}-11$ & $2.08 \mathrm{E}-10$ & $1.73 \mathrm{E}-10$ & 3.23E-10 \\
\hline 800 & 1.44E-11 & 4.87E-11 & 4.22E-11 & $9.59 \mathrm{E}-11$ & $1.52 \mathrm{E}-10$ & 3.10E-10 & 1.17E-10 & $2.78 \mathrm{E}-10$ & $1.82 \mathrm{E}-10$ & 3.59E-10 \\
\hline 900 & $2.21 \mathrm{E}-11$ & $5.22 \mathrm{E}-11$ & 6.13E-11 & $1.32 \mathrm{E}-10$ & $1.82 \mathrm{E}-10$ & $3.98 \mathrm{E}-10$ & $1.19 \mathrm{E}-10$ & $2.82 \mathrm{E}-10$ & $1.62 \mathrm{E}-10$ & $2.86 \mathrm{E}-10$ \\
\hline 1000 & $2.55 \mathrm{E}-11$ & 5.17E-11 & $6.80 \mathrm{E}-11$ & $1.46 \mathrm{E}-10$ & 2.33E-10 & 4.57E-10 & $1.11 \mathrm{E}-10$ & 3.75E-10 & $1.71 \mathrm{E}-10$ & 3.09E-10 \\
\hline 1100 & $2.53 \mathrm{E}-11$ & $6.01 \mathrm{E}-11$ & 8.07E-11 & $2.11 \mathrm{E}-10$ & $2.75 \mathrm{E}-10$ & $5.65 \mathrm{E}-10$ & $1.86 \mathrm{E}-10$ & $3.48 \mathrm{E}-10$ & 2.00E-10 & 3.53E-10 \\
\hline 1200 & $2.28 \mathrm{E}-11$ & 5.44E-11 & 8.35E-11 & $1.79 \mathrm{E}-10$ & 2.03E-10 & 5.98E-10 & 9.59E-11 & $4.49 \mathrm{E}-10$ & $1.74 \mathrm{E}-10$ & 3.09E-10 \\
\hline 1300 & $2.54 \mathrm{E}-11$ & 5.71E-11 & $7.59 \mathrm{E}-11$ & $1.80 \mathrm{E}-10$ & $2.39 \mathrm{E}-10$ & $5.12 \mathrm{E}-10$ & $1.52 \mathrm{E}-10$ & 3.56E-10 & $1.91 \mathrm{E}-10$ & 3.53E-10 \\
\hline 1400 & $2.90 \mathrm{E}-11$ & 6.13E-11 & 7.60E-11 & $2.15 \mathrm{E}-10$ & $2.97 \mathrm{E}-10$ & $5.87 \mathrm{E}-10$ & $2.06 \mathrm{E}-10$ & $3.95 \mathrm{E}-10$ & $2.91 \mathrm{E}-10$ & 4.45E-10 \\
\hline 1500 & $2.21 \mathrm{E}-11$ & 5.26E-11 & $5.28 \mathrm{E}-11$ & $1.08 \mathrm{E}-10$ & $2.23 \mathrm{E}-10$ & 4.32E-10 & $1.53 \mathrm{E}-10$ & 3.12E-10 & $2.62 \mathrm{E}-10$ & 4.41E-10 \\
\hline 1600 & 1.35E-11 & 3.98E-11 & 3.71E-11 & $9.76 \mathrm{E}-11$ & $1.44 \mathrm{E}-10$ & 3.63E-10 & $2.59 \mathrm{E}-10$ & $5.25 \mathrm{E}-10$ & $6.65 \mathrm{E}-10$ & 1.37E-09 \\
\hline 1700 & $2.05 \mathrm{E}-11$ & 4.73E-11 & 5.13E-11 & $1.13 \mathrm{E}-10$ & $1.93 \mathrm{E}-10$ & $4.58 \mathrm{E}-10$ & $1.59 \mathrm{E}-10$ & $3.58 \mathrm{E}-10$ & $2.38 \mathrm{E}-10$ & 4.61E-10 \\
\hline 1800 & $1.52 \mathrm{E}-11$ & 3.78E-11 & 3.47E-11 & 8.10E-11 & $1.61 \mathrm{E}-10$ & 3.54E-10 & $1.55 \mathrm{E}-10$ & 3.35E-10 & $2.76 \mathrm{E}-10$ & 4.87E-10 \\
\hline 1900 & $1.74 \mathrm{E}-11$ & 4.07E-11 & 4.35E-11 & $1.09 \mathrm{E}-10$ & 2.05E-10 & 4.79E-10 & $1.49 \mathrm{E}-10$ & $3.09 \mathrm{E}-10$ & $2.61 \mathrm{E}-10$ & $5.49 \mathrm{E}-10$ \\
\hline 2000 & $1.62 \mathrm{E}-11$ & 3.84E-11 & $5.40 \mathrm{E}-11$ & $1.17 \mathrm{E}-10$ & 2.37E-10 & $4.98 \mathrm{E}-10$ & $1.70 \mathrm{E}-10$ & 3.14E-10 & $2.59 \mathrm{E}-10$ & 4.33E-10 \\
\hline 2100 & $1.42 \mathrm{E}-11$ & 3.39E-11 & 4.64E-11 & $1.09 \mathrm{E}-10$ & 1.30E-10 & 4.83E-10 & 8.05E-11 & $2.97 \mathrm{E}-10$ & 1.43E-10 & 3.54E-10 \\
\hline 2200 & 1.46E-11 & 3.29E-11 & 4.49E-11 & 8.91E-11 & $1.51 \mathrm{E}-10$ & $3.68 \mathrm{E}-10$ & $9.85 \mathrm{E}-11$ & $2.25 \mathrm{E}-10$ & $1.36 \mathrm{E}-10$ & $2.76 \mathrm{E}-10$ \\
\hline 2300 & $1.05 \mathrm{E}-11$ & $2.54 \mathrm{E}-11$ & 3.02E-11 & $6.83 \mathrm{E}-11$ & 1.19E-10 & $2.91 \mathrm{E}-10$ & $6.54 \mathrm{E}-11$ & $1.78 \mathrm{E}-10$ & $1.42 \mathrm{E}-10$ & 2.73E-10 \\
\hline
\end{tabular}


Table 12. Lower and upper limits of the principal portion of highway power PDFs by center frequency $(40 \mathrm{~Hz}-80 \mathrm{~Hz})$ and hour for Wednesday, 15 February 2006. Vertical ground motion. Units: $\mathrm{m}^{2} / \mathrm{s}^{2}$.

\begin{tabular}{|c|c|c|c|c|c|c|c|c|}
\hline \multirow[b]{2}{*}{ Hour } & \multicolumn{2}{|c|}{$40 \mathrm{~Hz}$} & \multicolumn{2}{|c|}{$50 \mathrm{~Hz}$} & \multicolumn{2}{|c|}{$63 \mathrm{~Hz}$} & \multicolumn{2}{|c|}{$80 \mathrm{~Hz}$} \\
\hline & $\begin{array}{l}\text { Lower } \\
\text { Limit }\end{array}$ & $\begin{array}{l}\text { Upper } \\
\text { Limit }\end{array}$ & $\begin{array}{l}\text { Lower } \\
\text { Limit }\end{array}$ & $\begin{array}{l}\text { Upper } \\
\text { Limit }\end{array}$ & $\begin{array}{l}\text { Lower } \\
\text { Limit }\end{array}$ & $\begin{array}{l}\text { Upper } \\
\text { Limit }\end{array}$ & $\begin{array}{l}\text { Lower } \\
\text { Limit }\end{array}$ & $\begin{array}{l}\text { Upper } \\
\text { Limit }\end{array}$ \\
\hline 0 & 5.69E-11 & $1.31 \mathrm{E}-10$ & 3.67E-11 & 5.96E-11 & 3.30E-11 & 4.60E-11 & 3.29E-11 & 4.16E-11 \\
\hline 100 & 7.02E-11 & $1.22 \mathrm{E}-10$ & 3.64E-11 & $6.08 \mathrm{E}-11$ & 3.12E-11 & 4.39E-11 & 3.35E-11 & 3.99E-11 \\
\hline 200 & $6.15 \mathrm{E}-11$ & $1.05 \mathrm{E}-10$ & 2.94E-11 & 6.30E-11 & 3.05E-11 & 4.10E-11 & $3.42 \mathrm{E}-11$ & 4.13E-11 \\
\hline 300 & 5.34E-11 & $1.20 \mathrm{E}-10$ & 3.16E-11 & 5.01E-11 & 3.28E-11 & 4.31E-11 & $3.18 \mathrm{E}-11$ & 3.92E-11 \\
\hline 400 & 4.45E-11 & $1.05 \mathrm{E}-10$ & $2.98 \mathrm{E}-11$ & $4.46 \mathrm{E}-11$ & 2.97E-11 & 3.85E-11 & 3.14E-11 & 3.72E-11 \\
\hline 500 & $6.99 \mathrm{E}-11$ & $1.46 \mathrm{E}-10$ & 3.27E-11 & $5.04 \mathrm{E}-11$ & 3.01E-11 & 4.22E-11 & 3.06E-11 & $3.91 \mathrm{E}-11$ \\
\hline 600 & 8.43E-11 & $1.49 \mathrm{E}-10$ & 3.62E-11 & $5.47 \mathrm{E}-11$ & 3.20E-11 & 4.31E-11 & 3.23E-11 & 4.01E-11 \\
\hline 700 & $9.02 \mathrm{E}-11$ & $1.64 \mathrm{E}-10$ & 3.79E-11 & $6.12 \mathrm{E}-11$ & 3.13E-11 & 4.21E-11 & 3.09E-11 & 3.95E-11 \\
\hline 800 & 9.97E-11 & $2.25 \mathrm{E}-10$ & 4.95E-11 & $9.71 \mathrm{E}-11$ & 3.10E-11 & 4.19E-11 & $3.16 \mathrm{E}-11$ & 3.86E-11 \\
\hline 900 & 7.10E-11 & 1.63E-10 & 3.56E-11 & 8.40E-11 & 3.05E-11 & 4.36E-11 & 3.22E-11 & 3.93E-11 \\
\hline 1000 & 8.18E-11 & $1.55 \mathrm{E}-10$ & 3.26E-11 & $6.32 \mathrm{E}-11$ & $2.58 \mathrm{E}-11$ & 4.63E-11 & 3.03E-11 & 4.15E-11 \\
\hline 1100 & 8.66E-11 & 1.77E-10 & 3.83E-11 & 6.61E-11 & 3.03E-11 & 4.33E-11 & $3.25 \mathrm{E}-11$ & 4.09E-11 \\
\hline 1200 & $6.85 \mathrm{E}-11$ & $1.29 \mathrm{E}-10$ & 3.72E-11 & $6.08 \mathrm{E}-11$ & 2.99E-11 & 4.08E-11 & 3.01E-11 & $4.02 \mathrm{E}-11$ \\
\hline 1300 & 6.77E-11 & $1.38 \mathrm{E}-10$ & 4.00E-11 & $6.30 \mathrm{E}-11$ & 3.10E-11 & $4.22 \mathrm{E}-11$ & 3.11E-11 & 4.07E-11 \\
\hline 1400 & 8.13E-11 & $1.52 \mathrm{E}-10$ & 4.68E-11 & 6.89E-01 & 3.25E-11 & 4.75E-11 & 9.94E-11 & $1.87 \mathrm{E}-10$ \\
\hline 1500 & $1.06 \mathrm{E}-10$ & 2.14E-10 & 1.01E-10 & 2.06E-10 & 1.04E-10 & $1.97 \mathrm{E}-10$ & 3.64E-11 & 4.89E-11 \\
\hline 1600 & 1.35E-10 & 3.71E-10 & 8.05E-11 & $1.63 \mathrm{E}-10$ & 2.86E-11 & 4.61E-11 & 2.95E-11 & 4.01E-11 \\
\hline 1700 & 8.57E-11 & $1.85 \mathrm{E}-10$ & 5.42E-11 & $1.27 \mathrm{E}-10$ & 3.99E-11 & 5.73E-11 & 3.23E-11 & 4.20E-11 \\
\hline 1800 & $2.29 \mathrm{E}-10$ & 3.62E-10 & 4.13E-11 & $7.56 \mathrm{E}-11$ & 3.61E-11 & 5.01E-11 & 4.49E-11 & 5.67E-11 \\
\hline 1900 & 1.73E-10 & 4.03E-10 & 4.14E-11 & 5.98E-11 & 3.97E-11 & 5.21E-11 & 4.09E-11 & 5.39E-11 \\
\hline 2000 & $7.58 \mathrm{E}-11$ & 2.06E-10 & 4.43E-11 & 6.93E-11 & 3.47E-11 & 4.74E-11 & $3.16 \mathrm{E}-11$ & 4.08E-11 \\
\hline 2100 & $7.28 \mathrm{E}-11$ & $1.89 \mathrm{E}-10$ & 3.33E-11 & 5.99E-11 & $2.79 \mathrm{E}-11$ & 4.55E-11 & 3.04E-11 & 3.93E-11 \\
\hline 2200 & $6.24 \mathrm{E}-11$ & $1.56 \mathrm{E}-10$ & 3.44E-11 & $5.28 \mathrm{E}-11$ & 2.68E-11 & 4.17E-11 & $2.95 \mathrm{E}-11$ & 4.00E-11 \\
\hline 2300 & $1.12 \mathrm{E}-10$ & 2.21E-10 & $1.37 \mathrm{E}-10$ & $1.86 \mathrm{E}-10$ & 8.95E-11 & 1.19E-10 & $3.58 \mathrm{E}-11$ & $4.55 \mathrm{E}-11$ \\
\hline
\end{tabular}


Table 13. Lower and upper limits of the principal portion of highway power PDFs by center frequency $(4 \mathrm{~Hz}-10 \mathrm{~Hz})$ and hour for Sunday, 19 February 2006. Vertical ground motion.

Units: $\mathrm{m}^{2} / \mathrm{s}^{2}$.

\begin{tabular}{|c|c|c|c|c|c|c|c|c|c|c|}
\hline \multirow[b]{2}{*}{ Hour } & \multicolumn{2}{|c|}{$4 \mathrm{~Hz}$} & \multicolumn{2}{|c|}{$5 \mathrm{~Hz}$} & \multicolumn{2}{|c|}{$6 \mathrm{~Hz}$} & \multicolumn{2}{|c|}{$8 \mathrm{~Hz}$} & \multicolumn{2}{|c|}{$10 \mathrm{~Hz}$} \\
\hline & $\begin{array}{l}\text { Lower } \\
\text { Limit }\end{array}$ & $\begin{array}{l}\text { Upper } \\
\text { Limit }\end{array}$ & $\begin{array}{l}\text { Lower } \\
\text { Limit }\end{array}$ & $\begin{array}{l}\text { Upper } \\
\text { Limit }\end{array}$ & $\begin{array}{l}\text { Lower } \\
\text { Limit }\end{array}$ & $\begin{array}{l}\text { Upper } \\
\text { Limit }\end{array}$ & $\begin{array}{l}\text { Lower } \\
\text { Limit }\end{array}$ & $\begin{array}{l}\text { Upper } \\
\text { Limit }\end{array}$ & $\begin{array}{l}\text { Lower } \\
\text { Limit }\end{array}$ & $\begin{array}{l}\text { Upper } \\
\text { Limit }\end{array}$ \\
\hline 0 & 7.14E-13 & 2.34E-12 & 7.23E-13 & 2.13E-12 & 8.80E-13 & 2.85E-12 & $1.25 \mathrm{E}-12$ & $4.32 \mathrm{E}-12$ & $1.27 \mathrm{E}-12$ & 3.38E-12 \\
\hline 100 & 7.56E-13 & 2.41E-12 & $6.05 \mathrm{E}-13$ & $2.81 \mathrm{E}-12$ & $8.88 \mathrm{E}-13$ & $3.49 \mathrm{E}-12$ & $1.06 \mathrm{E}-12$ & 5.90E-12 & 1.30E-12 & 4.74E-12 \\
\hline 200 & 8.23E-13 & 2.83E-12 & $7.71 \mathrm{E}-13$ & $2.56 \mathrm{E}-12$ & $1.02 \mathrm{E}-12$ & $3.48 \mathrm{E}-12$ & $1.15 \mathrm{E}-12$ & $5.10 \mathrm{E}-12$ & $1.04 \mathrm{E}-12$ & 4.84E-12 \\
\hline 300 & 8.21E-13 & 2.95E-12 & 7.80E-13 & 2.63E-12 & $1.14 \mathrm{E}-12$ & 3.33E-12 & $1.42 \mathrm{E}-12$ & $6.44 \mathrm{E}-12$ & $1.47 \mathrm{E}-12$ & 6.15E-12 \\
\hline 400 & $9.89 \mathrm{E}-13$ & 2.66E-12 & 7.35E-13 & 2.68E-12 & $1.02 \mathrm{E}-12$ & 3.53E-12 & $1.43 \mathrm{E}-12$ & 5.99E-12 & $1.74 \mathrm{E}-12$ & 4.04E-12 \\
\hline 500 & 5.60E-13 & 3.65E-12 & 9.04E-13 & 2.64E-12 & 1.06E-12 & 3.69E-12 & 1.43E-12 & 4.37E-12 & $1.57 \mathrm{E}-12$ & 4.25E-12 \\
\hline 600 & $9.31 \mathrm{E}-13$ & 4.48E-12 & 1.12E-12 & 3.80E-12 & $1.52 \mathrm{E}-12$ & 5.05E-12 & 2.47E-12 & $7.76 \mathrm{E}-12$ & $2.57 \mathrm{E}-12$ & 7.06E-12 \\
\hline 700 & $1.08 \mathrm{E}-12$ & 3.89E-12 & $1.12 \mathrm{E}-12$ & 4.69E-12 & 1.96E-12 & $5.58 \mathrm{E}-12$ & $2.89 \mathrm{E}-12$ & 8.90E-12 & 2.83E-12 & 7.01E-12 \\
\hline 800 & $1.24 \mathrm{E}-12$ & 7.83E-12 & $1.51 \mathrm{E}-12$ & $6.18 \mathrm{E}-12$ & $1.81 \mathrm{E}-12$ & $6.55 \mathrm{E}-12$ & $1.75 \mathrm{E}-12$ & $1.25 \mathrm{E}-11$ & $2.08 \mathrm{E}-12$ & 1.03E-11 \\
\hline 900 & 1.37E-12 & 7.41E-12 & $1.72 \mathrm{E}-12$ & $5.66 \mathrm{E}-12$ & 2.17E-12 & $6.23 \mathrm{E}-12$ & 2.71E-12 & $9.27 \mathrm{E}-12$ & 3.18E-12 & 8.34E-12 \\
\hline 1000 & $1.91 \mathrm{E}-12$ & 7.10E-12 & 2.09E-12 & $6.57 \mathrm{E}-12$ & 2.96E-12 & 8.00E-12 & 4.18E-12 & $1.22 \mathrm{E}-11$ & 4.97E-12 & 1.37E-11 \\
\hline 1100 & 2.24E-12 & 7.56E-12 & $1.97 \mathrm{E}-12$ & $6.77 \mathrm{E}-12$ & 2.92E-12 & 7.34E-12 & 4.16E-12 & $1.18 \mathrm{E}-11$ & 4.38E-12 & 1.16E-11 \\
\hline 1200 & 1.98E-12 & $8.78 \mathrm{E}-12$ & $2.10 \mathrm{E}-12$ & 8.14E-12 & 3.25E-12 & 8.61E-12 & 5.10E-12 & $1.27 \mathrm{E}-11$ & 5.15E-12 & 1.20E-11 \\
\hline 1300 & 2.00E-12 & 7.32E-12 & $1.88 \mathrm{E}-12$ & $6.78 \mathrm{E}-12$ & $2.82 \mathrm{E}-12$ & 8.60E-12 & 4.16E-12 & $1.49 \mathrm{E}-11$ & $3.98 \mathrm{E}-12$ & $1.62 \mathrm{E}-11$ \\
\hline 1400 & 2.77E-12 & $9.81 \mathrm{E}-12$ & $2.88 \mathrm{E}-12$ & 7.15E-12 & 3.14E-12 & $9.45 \mathrm{E}-12$ & $5.78 \mathrm{E}-12$ & $1.37 \mathrm{E}-11$ & $5.69 \mathrm{E}-12$ & 1.46E-11 \\
\hline 1500 & 1.93E-12 & 1.05E-11 & $2.51 \mathrm{E}-12$ & $9.14 \mathrm{E}-12$ & $1.97 \mathrm{E}-12$ & 1.20E-11 & $5.21 \mathrm{E}-12$ & $1.78 \mathrm{E}-11$ & $6.29 \mathrm{E}-12$ & 1.69E-11 \\
\hline 1600 & 2.38E-12 & 6.37E-12 & 2.32E-12 & 7.69E-12 & 3.56E-12 & 8.90E-12 & 5.64E-12 & $1.34 \mathrm{E}-11$ & 5.93E-12 & 1.33E-11 \\
\hline 1700 & 2.51E-12 & 9.33E-12 & 2.94E-12 & 7.97E-12 & 4.23E-12 & 9.83E-12 & 5.83E-12 & $1.14 \mathrm{E}-11$ & 7.04E-12 & 1.48E-11 \\
\hline 1800 & 2.21E-12 & $6.53 \mathrm{E}-12$ & 2.13E-12 & $5.96 \mathrm{E}-12$ & 3.16E-12 & 8.46E-12 & $5.76 \mathrm{E}-12$ & $1.43 \mathrm{E}-11$ & 5.11E-12 & 1.43E-11 \\
\hline 1900 & 2.49E-12 & 7.32E-12 & 2.12E-12 & 6.87E-12 & 2.89E-12 & 8.08E-12 & 4.83E-12 & $1.18 \mathrm{E}-11$ & 4.63E-12 & 1.29E-11 \\
\hline 2000 & 2.17E-12 & 6.66E-12 & $1.95 \mathrm{E}-12$ & 7.20E-12 & 2.65E-12 & 8.54E-12 & 4.33E-12 & $1.17 \mathrm{E}-11$ & 4.37E-12 & 1.18E-11 \\
\hline 2100 & 1.38E-12 & 6.19E-12 & $1.55 \mathrm{E}-12$ & $5.92 \mathrm{E}-12$ & $2.57 \mathrm{E}-12$ & 8.38E-12 & 4.77E-12 & $1.23 \mathrm{E}-11$ & $3.86 \mathrm{E}-12$ & 1.16E-11 \\
\hline 2200 & 1.47E-12 & 5.41E-12 & 1.64E-12 & 4.92E-12 & $2.25 \mathrm{E}-12$ & $6.11 \mathrm{E}-12$ & 3.23E-12 & $1.04 \mathrm{E}-11$ & 2.73E-12 & 1.10E-11 \\
\hline 2300 & 1.33E-12 & 4.73E-12 & 1.36E-12 & 5.41E-12 & 2.16E-12 & 5.35E-12 & 3.57E-12 & $8.48 \mathrm{E}-12$ & $2.57 \mathrm{E}-12$ & $9.46 \mathrm{E}-12$ \\
\hline
\end{tabular}


Table 14. Lower and upper limits of the principal portion of highway power PDFs by center frequency $(12.5 \mathrm{~Hz}-31.5 \mathrm{~Hz})$ and hour for Sunday, 19 February 2006. Vertical ground motion. Units: $\mathrm{m}^{2} / \mathrm{s}^{2}$.

\begin{tabular}{|c|c|c|c|c|c|c|c|c|c|c|}
\hline \multirow[b]{2}{*}{ Hour } & \multicolumn{2}{|c|}{$12.5 \mathrm{~Hz}$} & \multicolumn{2}{|c|}{$16 \mathrm{~Hz}$} & \multicolumn{2}{|c|}{$20 \mathrm{~Hz}$} & \multicolumn{2}{|c|}{$25 \mathrm{~Hz}$} & \multicolumn{2}{|c|}{$31.5 \mathrm{~Hz}$} \\
\hline & $\begin{array}{l}\text { Lower } \\
\text { Limit }\end{array}$ & $\begin{array}{l}\text { Upper } \\
\text { Limit }\end{array}$ & $\begin{array}{l}\text { Lower } \\
\text { Limit }\end{array}$ & $\begin{array}{l}\text { Upper } \\
\text { Limit }\end{array}$ & $\begin{array}{l}\text { Lower } \\
\text { Limit }\end{array}$ & $\begin{array}{l}\text { Upper } \\
\text { Limit }\end{array}$ & $\begin{array}{l}\text { Lower } \\
\text { Limit }\end{array}$ & $\begin{array}{l}\text { Upper } \\
\text { Limit }\end{array}$ & $\begin{array}{l}\text { Lower } \\
\text { Limit }\end{array}$ & $\begin{array}{l}\text { Upper } \\
\text { Limit }\end{array}$ \\
\hline 0 & $2.18 \mathrm{E}-12$ & 4.31E-12 & 4.75E-12 & 1.09E-11 & $1.62 \mathrm{E}-11$ & 4.97E-11 & 2.14E-11 & 4.43E-11 & 3.43E-11 & 8.46E-11 \\
\hline 100 & 2.08E-12 & $5.22 \mathrm{E}-12$ & $4.52 \mathrm{E}-12$ & 9.34E-12 & $1.78 \mathrm{E}-11$ & 5.00E-11 & 1.94E-11 & 4.61E-11 & 3.08E-11 & $6.57 \mathrm{E}-11$ \\
\hline 200 & $1.90 \mathrm{E}-12$ & 4.91E-12 & 4.01E-12 & 8.91E-12 & 1.37E-11 & 4.19E-11 & $1.92 \mathrm{E}-11$ & 3.63E-11 & 3.03E-11 & $6.22 \mathrm{E}-11$ \\
\hline 300 & $2.27 \mathrm{E}-12$ & 5.39E-12 & 4.07E-12 & $7.80 \mathrm{E}-12$ & 1.33E-11 & 3.11E-11 & $1.88 \mathrm{E}-11$ & $3.44 \mathrm{E}-11$ & 3.07E-11 & $5.66 \mathrm{E}-11$ \\
\hline 400 & $2.12 \mathrm{E}-12$ & 5.09E-12 & 4.31E-12 & $9.76 \mathrm{E}-12$ & 1.64E-11 & 4.00E-11 & $2.20 \mathrm{E}-11$ & 3.65E-11 & 3.24E-11 & 5.20E-11 \\
\hline 500 & 2.35E-12 & 5.06E-12 & 4.54E-12 & 8.30E-12 & $1.24 \mathrm{E}-11$ & 2.99E-11 & 2.13E-11 & 3.33E-11 & 3.50E-11 & 5.95E-11 \\
\hline 600 & $2.46 \mathrm{E}-12$ & 6.37E-12 & 4.70E-12 & $9.25 \mathrm{E}-12$ & $1.54 \mathrm{E}-11$ & 3.07E-11 & $2.58 \mathrm{E}-11$ & 3.91E-11 & 3.52E-11 & 5.73E-11 \\
\hline 700 & 3.27E-12 & $7.08 \mathrm{E}-12$ & $6.00 \mathrm{E}-12$ & $1.19 \mathrm{E}-11$ & $1.81 \mathrm{E}-11$ & 3.65E-11 & 3.91E-11 & 5.93E-11 & $5.76 \mathrm{E}-11$ & $8.82 \mathrm{E}-11$ \\
\hline 800 & $2.88 \mathrm{E}-12$ & 8.35E-12 & 7.01E-12 & $1.42 \mathrm{E}-11$ & 2.53E-11 & $5.72 \mathrm{E}-11$ & 5.16E-11 & 8.32E-11 & 5.98E-11 & $1.14 \mathrm{E}-10$ \\
\hline 900 & 3.48E-12 & $9.26 \mathrm{E}-12$ & 4.71E-12 & $1.38 \mathrm{E}-11$ & $2.49 \mathrm{E}-11$ & $4.58 \mathrm{E}-11$ & 4.85E-11 & 7.62E-11 & $5.56 \mathrm{E}-11$ & 8.04E-11 \\
\hline 1000 & 5.54E-12 & $1.51 \mathrm{E}-11$ & 8.27E-12 & 2.05E-11 & 3.10E-11 & $6.81 \mathrm{E}-11$ & 6.03E-11 & $9.62 \mathrm{E}-11$ & 5.94E-11 & $9.93 \mathrm{E}-11$ \\
\hline 1100 & 4.67E-12 & $1.61 \mathrm{E}-11$ & $6.01 \mathrm{E}-12$ & $2.58 \mathrm{E}-11$ & 3.31E-11 & $6.95 \mathrm{E}-11$ & 4.51E-11 & $1.02 \mathrm{E}-10$ & $5.24 \mathrm{E}-11$ & $9.76 \mathrm{E}-11$ \\
\hline 1200 & 6.67E-12 & 1.63E-11 & 8.25E-12 & $2.26 \mathrm{E}-11$ & 3.09E-11 & 6.04E-11 & 4.38E-11 & 7.05E-11 & 4.68E-11 & 7.61E-11 \\
\hline 1300 & $6.11 \mathrm{E}-12$ & 1.46E-11 & 7.91E-12 & $2.29 \mathrm{E}-11$ & 3.62E-11 & 7.43E-11 & 4.62E-11 & 7.65E-11 & 5.57E-11 & 7.62E-11 \\
\hline 1400 & 6.16E-12 & $1.38 \mathrm{E}-11$ & 9.30E-12 & $1.81 \mathrm{E}-11$ & 3.59E-11 & 6.76E-11 & 4.35E-11 & 8.40E-11 & 4.91E-11 & 8.01E-11 \\
\hline 1500 & 7.51E-12 & $2.42 \mathrm{E}-11$ & $9.38 \mathrm{E}-12$ & $2.37 \mathrm{E}-11$ & 3.29E-11 & 6.63E-11 & 4.31E-11 & 7.71E-11 & $4.88 \mathrm{E}-11$ & $9.05 \mathrm{E}-11$ \\
\hline 1600 & $6.27 \mathrm{E}-12$ & 1.76E-11 & 8.85E-12 & $1.72 \mathrm{E}-11$ & $2.44 \mathrm{E}-11$ & 5.66E-11 & 4.20E-11 & 7.12E-11 & $6.79 \mathrm{E}-11$ & 1.12E-10 \\
\hline 1700 & 7.83E-12 & $1.62 \mathrm{E}-11$ & 7.81E-12 & $1.71 \mathrm{E}-11$ & $2.99 \mathrm{E}-11$ & 4.87E-11 & 3.44E-11 & 5.55E-11 & $6.69 \mathrm{E}-11$ & $1.22 \mathrm{E}-10$ \\
\hline 1800 & 5.61E-12 & 1.30E-11 & 6.80E-12 & $1.40 \mathrm{E}-11$ & 2.64E-11 & $4.72 \mathrm{E}-11$ & 2.97E-11 & 5.08E-11 & $5.43 \mathrm{E}-11$ & $9.28 \mathrm{E}-11$ \\
\hline 1900 & 5.54E-12 & $1.20 \mathrm{E}-11$ & 8.28E-12 & $1.49 \mathrm{E}-11$ & 3.07E-11 & 5.38E-11 & 3.50E-11 & 5.36E-11 & 4.99E-11 & $9.93 \mathrm{E}-11$ \\
\hline 2000 & $5.28 \mathrm{E}-12$ & $1.09 \mathrm{E}-11$ & 7.86E-12 & $1.32 \mathrm{E}-11$ & $2.78 \mathrm{E}-11$ & 4.79E-11 & $3.41 \mathrm{E}-11$ & 5.16E-11 & 4.64E-11 & 7.54E-11 \\
\hline 2100 & 5.05E-12 & 1.14E-11 & $6.99 \mathrm{E}-12$ & $1.38 \mathrm{E}-11$ & 2.07E-11 & 4.18E-11 & 2.76E-11 & 4.65E-11 & 4.23E-11 & $6.86 \mathrm{E}-11$ \\
\hline 2200 & 3.65E-12 & 1.06E-11 & 5.99E-12 & $1.52 \mathrm{E}-11$ & 2.14E-11 & 4.74E-11 & $2.56 \mathrm{E}-11$ & 4.65E-11 & 3.55E-11 & $6.03 \mathrm{E}-11$ \\
\hline 2300 & 3.80E-12 & 9.05E-12 & 5.62E-12 & 1.10E-11 & $1.42 \mathrm{E}-11$ & 3.30E-11 & 1.93E-11 & 3.31E-11 & 2.60E-11 & 5.51E-11 \\
\hline
\end{tabular}


Table 15. Lower and upper limits of the principal portion of highway power PDFs by center frequency $(40 \mathrm{~Hz}-80 \mathrm{~Hz})$ and hour for Sunday, 19 February 2006. Vertical ground motion. Units: $\mathrm{m}^{2} / \mathrm{s}^{2}$.

\begin{tabular}{|c|c|c|c|c|c|c|c|c|}
\hline \multirow[b]{2}{*}{ Hour } & \multicolumn{2}{|c|}{$40 \mathrm{~Hz}$} & \multicolumn{2}{|c|}{$50 \mathrm{~Hz}$} & \multicolumn{2}{|c|}{$63 \mathrm{~Hz}$} & \multicolumn{2}{|c|}{$80 \mathrm{~Hz}$} \\
\hline & $\begin{array}{l}\text { Lower } \\
\text { Limit }\end{array}$ & $\begin{array}{l}\text { Upper } \\
\text { Limit }\end{array}$ & $\begin{array}{l}\text { Lower } \\
\text { Limit }\end{array}$ & $\begin{array}{l}\text { Upper } \\
\text { Limit }\end{array}$ & $\begin{array}{l}\text { Lower } \\
\text { Limit }\end{array}$ & $\begin{array}{l}\text { Upper } \\
\text { Limit }\end{array}$ & $\begin{array}{l}\text { Lower } \\
\text { Limit }\end{array}$ & $\begin{array}{l}\text { Upper } \\
\text { Limit }\end{array}$ \\
\hline 0 & $2.28 \mathrm{E}-11$ & 4.61E-11 & $2.50 \mathrm{E}-11$ & 3.37E-11 & 3.09E-11 & 3.84E-11 & 3.36E-11 & $4.09 \mathrm{E}-11$ \\
\hline 100 & 2.30E-11 & 4.08E-11 & $2.38 \mathrm{E}-11$ & 3.40E-11 & 2.86E-11 & 3.51E-11 & 3.18E-11 & 3.86E-11 \\
\hline 200 & 2.09E-11 & 3.72E-11 & $2.40 \mathrm{E}-11$ & 3.07E-11 & 2.79E-11 & 3.62E-11 & 3.14E-11 & 3.80E-11 \\
\hline 300 & $1.79 \mathrm{E}-11$ & 3.56E-11 & $2.42 \mathrm{E}-11$ & 3.14E-11 & $2.86 \mathrm{E}-11$ & 3.53E-11 & 3.34E-11 & $3.99 \mathrm{E}-11$ \\
\hline 400 & 2.06E-11 & 3.83E-11 & 2.38E-11 & 3.18E-11 & 2.95E-11 & 3.59E-11 & $3.22 \mathrm{E}-11$ & $4.08 \mathrm{E}-11$ \\
\hline 500 & $2.09 \mathrm{E}-11$ & 3.37E-11 & $2.37 \mathrm{E}-11$ & $3.08 \mathrm{E}-11$ & $2.90 \mathrm{E}-11$ & 3.52E-11 & 3.35E-11 & $3.98 \mathrm{E}-11$ \\
\hline 600 & 2.16E-11 & 3.68E-11 & 2.37E-11 & 3.08E-11 & 2.74E-11 & 3.58E-11 & 3.24E-11 & 3.88E-11 \\
\hline 700 & 2.62E-11 & 5.41E-11 & $2.52 \mathrm{E}-11$ & 3.39E-11 & 2.61E-11 & 3.34E-11 & 3.25E-11 & 3.87E-11 \\
\hline 800 & 3.50E-11 & 5.69E-11 & 2.62E-11 & 3.70E-11 & $2.78 \mathrm{E}-11$ & 3.39E-11 & $2.95 \mathrm{E}-11$ & $3.49 \mathrm{E}-11$ \\
\hline 900 & $2.88 \mathrm{E}-11$ & 4.62E-11 & 2.69E-11 & 3.52E-11 & $2.76 \mathrm{E}-11$ & 3.40E-11 & 3.16E-11 & $3.72 \mathrm{E}-11$ \\
\hline 1000 & 3.36E-11 & 5.03E-11 & $2.84 \mathrm{E}-11$ & 4.05E-11 & $2.88 \mathrm{E}-11$ & 3.69E-11 & $2.84 \mathrm{E}-10$ & 3.89E-10 \\
\hline 1100 & 3.13E-11 & 4.70E-11 & $2.70 \mathrm{E}-11$ & $3.48 \mathrm{E}-11$ & 2.84E-11 & 3.49E-11 & $1.74 \mathrm{E}-10$ & 2.93E-10 \\
\hline 1200 & 2.72E-11 & 3.94E-11 & $2.56 \mathrm{E}-11$ & 3.23E-11 & $2.76 \mathrm{E}-11$ & $3.45 \mathrm{E}-11$ & 3.08E-11 & 3.64E-11 \\
\hline 1300 & 2.43E-11 & 3.83E-11 & $2.56 \mathrm{E}-11$ & 3.43E-11 & $2.74 \mathrm{E}-11$ & 3.41E-11 & 3.08E-11 & 3.74E-11 \\
\hline 1400 & 2.57E-11 & 3.80E-11 & $2.55 \mathrm{E}-11$ & 3.11E-11 & 2.99E-11 & 3.79E-11 & 3.11E-11 & 4.12E-01 \\
\hline 1500 & $2.46 \mathrm{E}-11$ & $3.90 \mathrm{E}-11$ & $2.37 \mathrm{E}-11$ & 3.29E-11 & $2.86 \mathrm{E}-11$ & 3.55E-11 & 3.54E-11 & 4.32E-11 \\
\hline 1600 & $2.76 \mathrm{E}-11$ & 4.55E-11 & 2.71E-11 & 3.52E-11 & 3.14E-11 & 3.85E-11 & 3.55E-11 & 4.24E-11 \\
\hline 1700 & $2.88 \mathrm{E}-11$ & 4.30E-11 & $2.69 \mathrm{E}-11$ & 3.58E-11 & 3.15E-11 & 3.86E-11 & 3.39E-11 & 4.05E-11 \\
\hline 1800 & $2.48 \mathrm{E}-11$ & 4.08E-11 & $2.58 \mathrm{E}-11$ & 3.37E-11 & 3.14E-11 & 3.81E-11 & $3.42 \mathrm{E}-11$ & $4.22 \mathrm{E}-11$ \\
\hline 1900 & 2.92E-11 & 4.24E-11 & 2.65E-11 & $3.45 \mathrm{E}-11$ & 3.14E-11 & 3.92E-11 & $3.41 \mathrm{E}-11$ & 4.03E-11 \\
\hline 2000 & 2.43E-11 & 3.56E-11 & 2.62E-11 & 3.37E-11 & 3.09E-11 & 3.68E-11 & 3.34E-11 & $3.92 \mathrm{E}-11$ \\
\hline 2100 & $2.41 \mathrm{E}-11$ & $3.45 \mathrm{E}-11$ & $2.53 \mathrm{E}-11$ & 3.38E-11 & 2.93E-11 & 3.72E-11 & 3.24E-11 & 4.00E-11 \\
\hline 2200 & $2.25 \mathrm{E}-11$ & 3.26E-11 & $2.58 \mathrm{E}-11$ & 3.19E-11 & 3.10E-11 & 3.88E-11 & $3.40 \mathrm{E}-11$ & 4.03E-11 \\
\hline 2300 & 1.97E-11 & 3.07E-11 & $2.43 \mathrm{E}-11$ & 3.14E-11 & 3.01E-11 & 3.75E-11 & $3.24 \mathrm{E}-11$ & 3.97E-11 \\
\hline
\end{tabular}



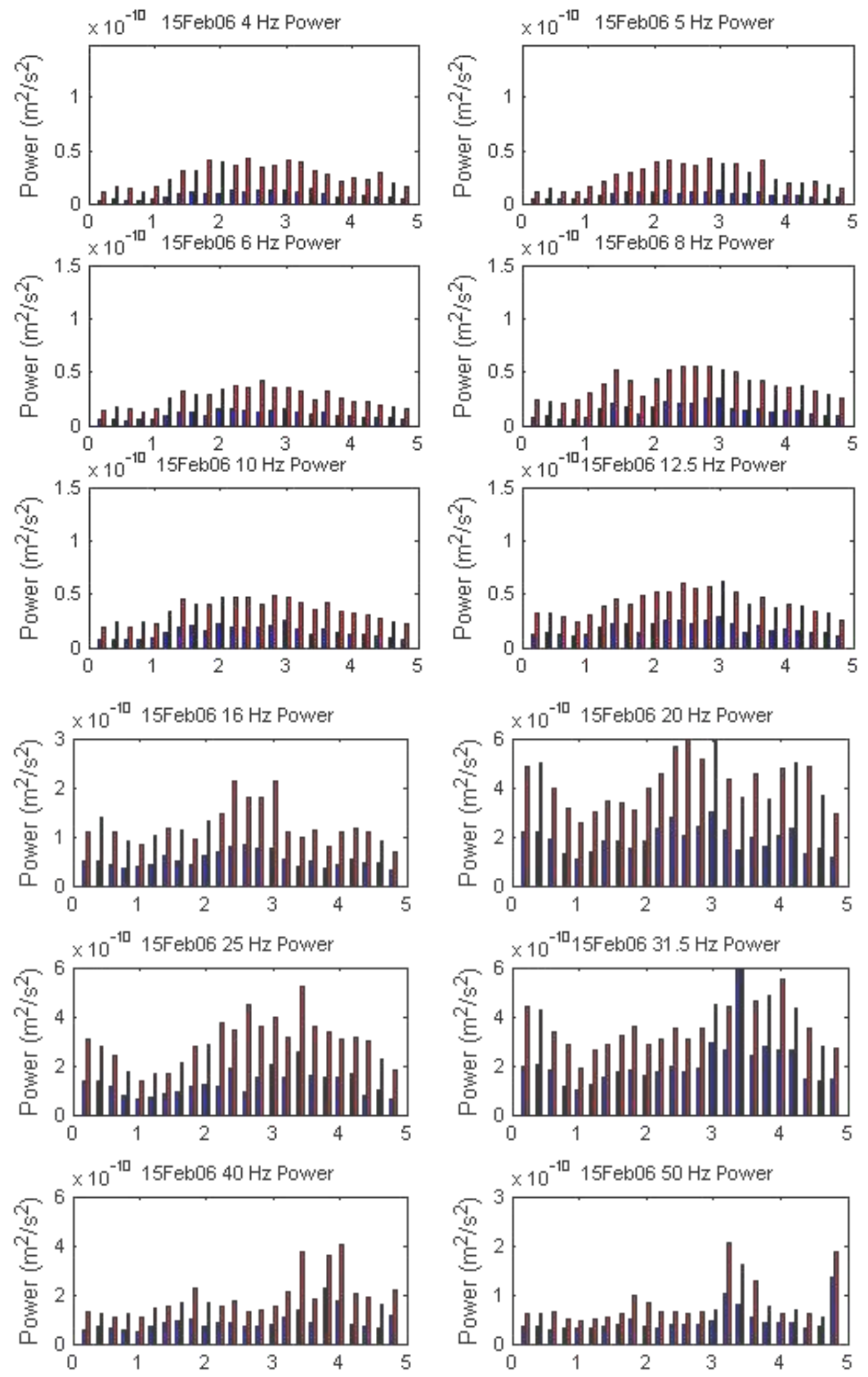

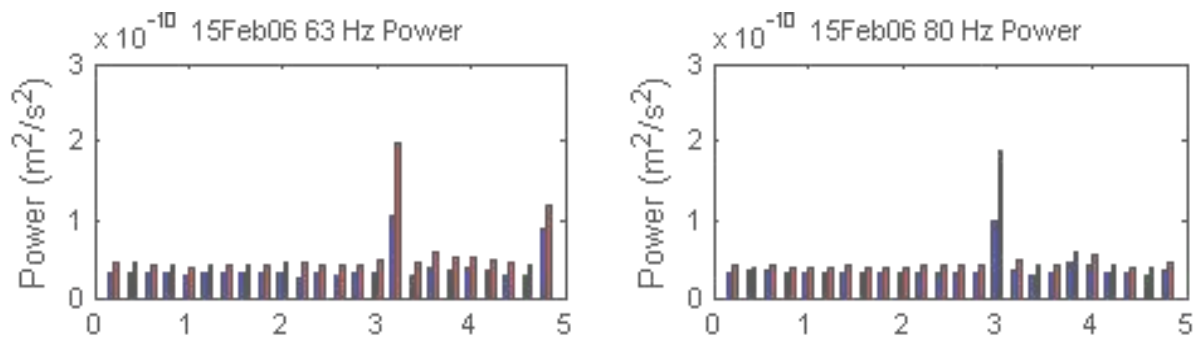

Figure 10.Power range of hourly PDFs of highway vertical ground motion by center frequency on Wednesday, 15 February 2006. The blue (red) bar indicates the selected lower (upper) limit of the principal portion of each power PDF. X-axis hourly designations are: 1 (0400), 2 (0900), 3 (1400), and 4 (1900). The y-axis upper limit is 1.5, 3, or $6 \times 10^{-10}$, depending on the center frequency.
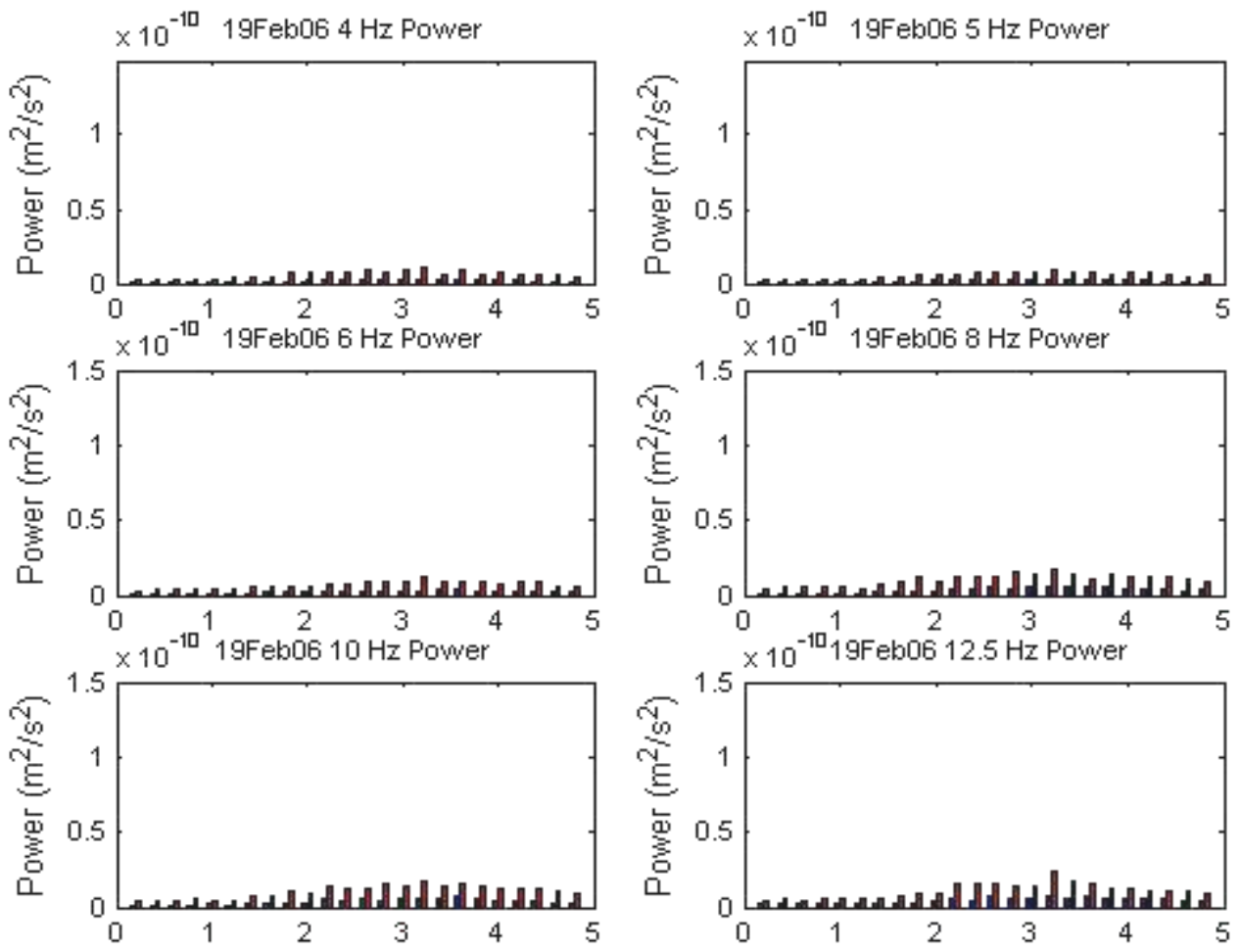

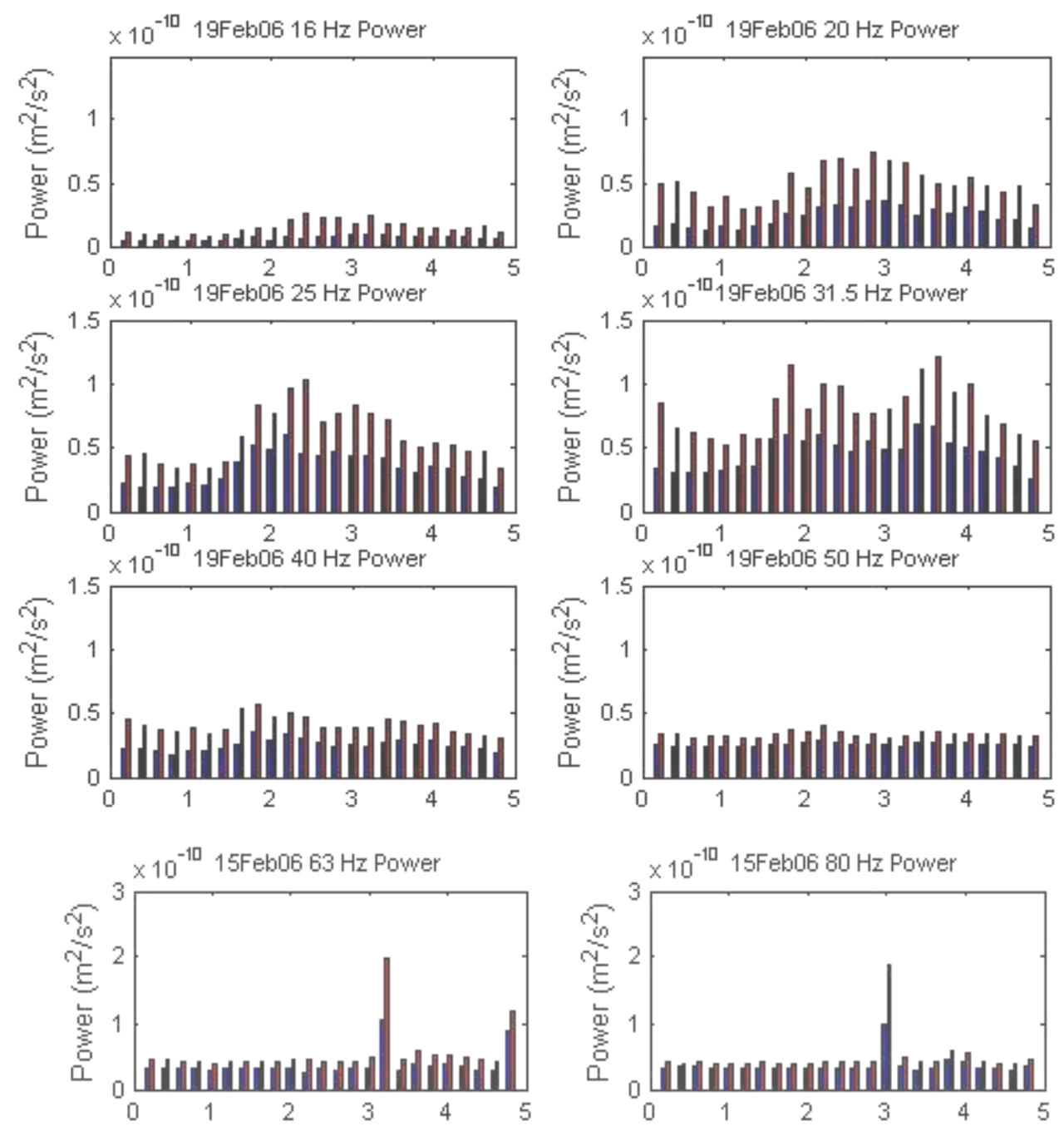

Figure 11. Power range of hourly PDFs of highway vertical ground motion by center frequency on Sunday, 19 February 2006. The blue (red) bar indicates the selected lower (upper) limit of the principal portion of each power PDF. X-axis hourly designations are: 1 (0400), 2 (0900), 3

(1400) and 4 (1900). The $y$-axis upper limit is 1.5 or $3 \times 10-10$, depending on the center frequency.

\subsubsection{Weekly variation}

The variation in vertical ground motion over seven days (15 - 21 February 2006) is shown with 4-Hz PDFs for the hours 0000 and 0800 (Figure 12). [Similar PDF plots for the other frequencies are included on the accompanying CD.] For both hours, ground motion at this frequency is weakest on 19 February, which would be consistent with the level of cultural activity, presumably including traffic, being lowest on Sunday mornings. Ground motion for the rest of the week is less intuitively predictable: during the $0000 \mathrm{hr}$, Monday ground motion is stronger than Sunday and weaker than 
the other days, whereas for the $0800 \mathrm{hr}$, Saturday ground motion is noticeably different from both Sunday and the other days.

For each of the seven days, a power range with each hour's PDF was determined by visual inspection of the plots. The upper and lower limits of the power range are not the extreme limits of the PDF; rather, they are a subjective determination of the principal portion of a PDF range, excluding low-amplitude oscillatory tails. The selected limits were tabulated for each center frequency (Tables 16-18) and plotted (Figure 13). For center frequencies of $4-12.5 \mathrm{~Hz}$, ground motion each day is stronger in the $0800 \mathrm{hr}$ than the $0000 \mathrm{hr}$. At higher frequencies, there is no consistency as to which hour the ground motion is stronger.

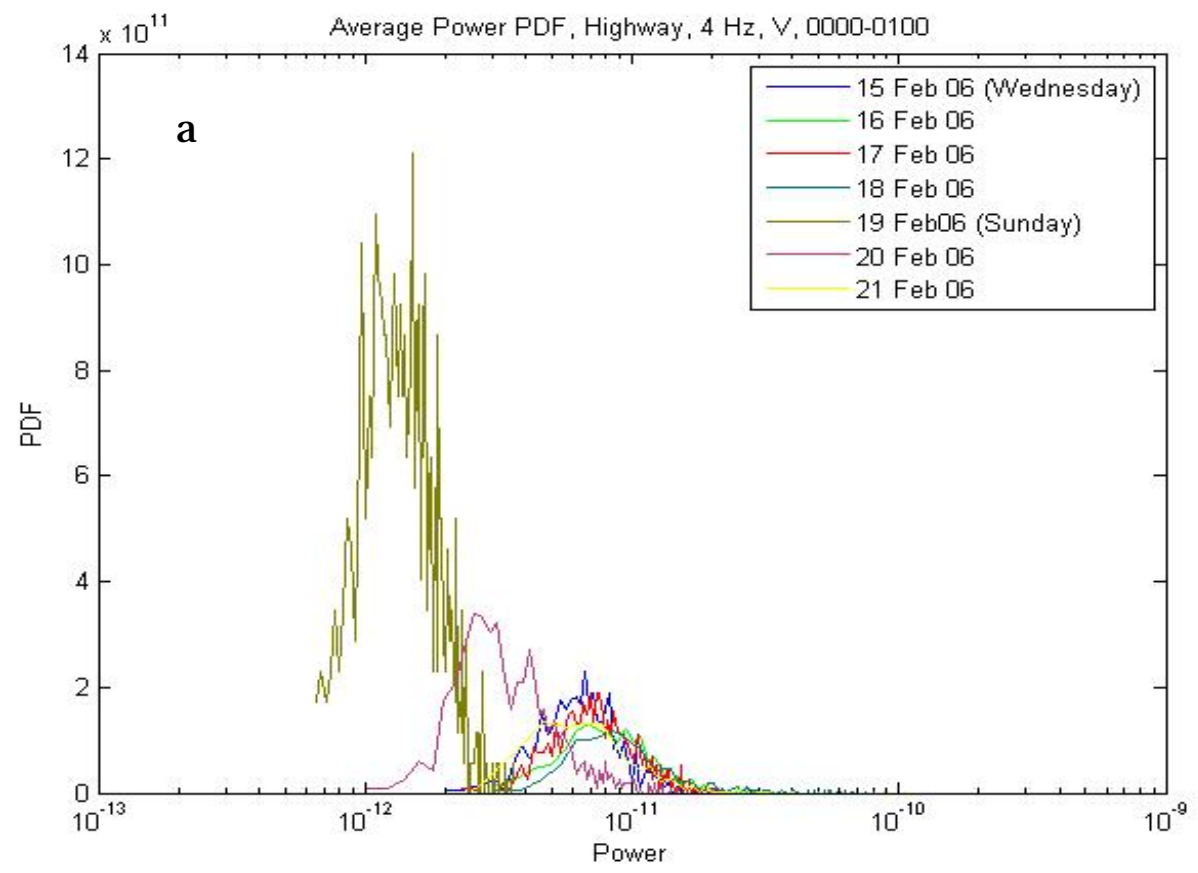




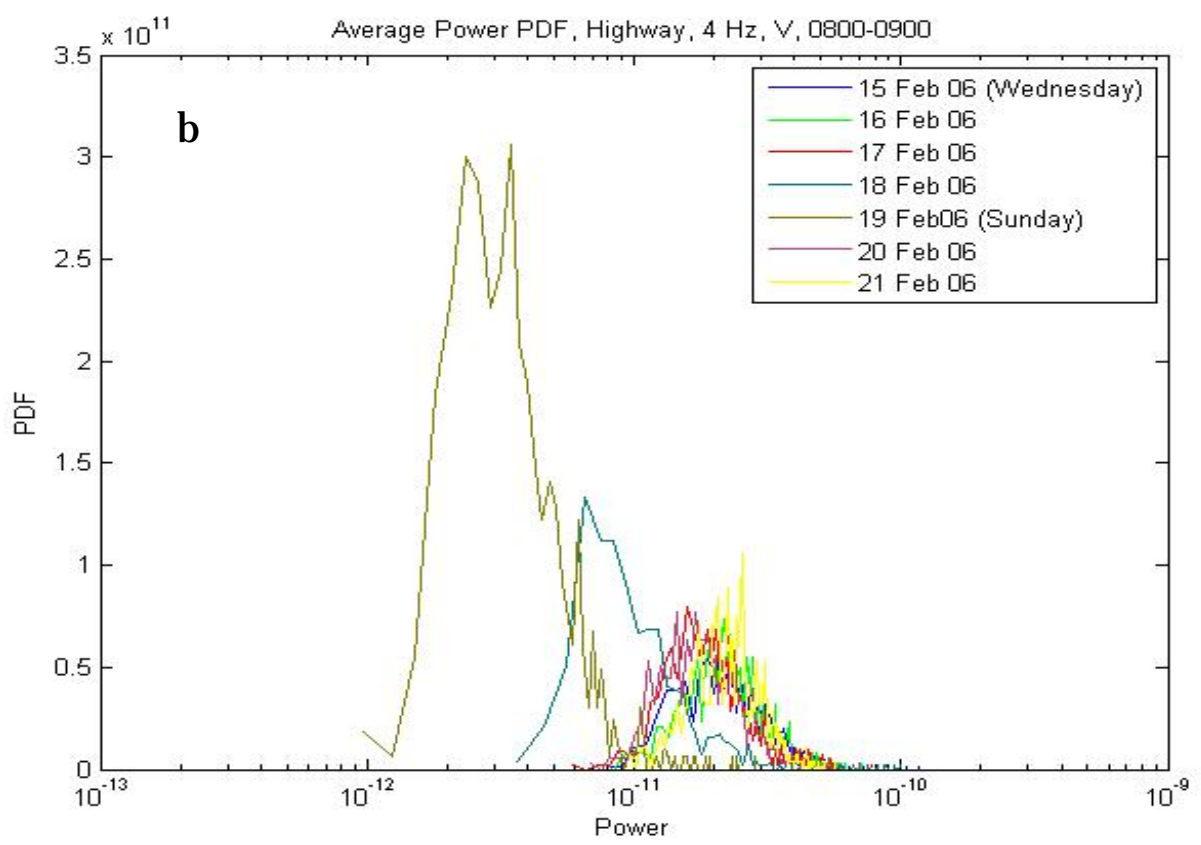

Figure 12. Power PDFs at 4-Hz center frequency for vertical ground motion at the highway site on seven days, 14 - 21 February 2006, during the hours of (a) $0000-0100$ and (b) 0800 0900.

Table 16. Lower and upper limits of the principal portion of highway power PDFs by center frequency $(4 \mathrm{~Hz}-10 \mathrm{~Hz})$ for the hours of 0000 and 0800 on seven days, Wednesday, 15

February through Tuesday, 21 February 2006 . Vertical ground motion. Units: $\mathrm{m}^{2} / \mathrm{s}^{2}$.

\begin{tabular}{|c|c|c|c|c|c|c|c|c|c|c|}
\hline \multirow[b]{2}{*}{$\begin{array}{l}\text { Day / } \\
\text { hour }\end{array}$} & \multicolumn{2}{|c|}{$4 \mathrm{~Hz}$} & \multicolumn{2}{|c|}{$5 \mathrm{~Hz}$} & \multicolumn{2}{|c|}{$6 \mathrm{~Hz}$} & \multicolumn{2}{|c|}{$8 \mathrm{~Hz}$} & \multicolumn{2}{|c|}{$10 \mathrm{~Hz}$} \\
\hline & $\begin{array}{l}\text { Lower } \\
\text { Limit }\end{array}$ & $\begin{array}{l}\text { Upper } \\
\text { Limit }\end{array}$ & $\begin{array}{l}\text { Lower } \\
\text { Limit }\end{array}$ & $\begin{array}{l}\text { Upper } \\
\text { Limit }\end{array}$ & $\begin{array}{l}\text { Lower } \\
\text { Limit }\end{array}$ & $\begin{array}{l}\text { Upper } \\
\text { Limit }\end{array}$ & $\begin{array}{l}\text { Lower } \\
\text { Limit }\end{array}$ & $\begin{array}{l}\text { Upper } \\
\text { Limit }\end{array}$ & $\begin{array}{l}\text { Lower } \\
\text { Limit }\end{array}$ & $\begin{array}{l}\text { Upper } \\
\text { Limit }\end{array}$ \\
\hline $\begin{array}{l}15 \text { Feb } \\
0000\end{array}$ & 3.33E-12 & $1.08 \mathrm{E}-11$ & 3.75E-12 & $1.08 \mathrm{E}-11$ & $5.78 \mathrm{E}-12$ & $1.38 \mathrm{E}-11$ & 7.22E-12 & 2.32E-11 & 7.17E-12 & 1.93E-11 \\
\hline $\begin{array}{l}15 \text { Feb } \\
0800\end{array}$ & 8.99E-12 & 4.05E-11 & $1.04 \mathrm{E}-11$ & 3.21E-11 & 8.74E-12 & 2.95E-11 & $1.03 \mathrm{E}-11$ & $2.71 \mathrm{E}-11$ & 1.64E-11 & 3.97E-11 \\
\hline $\begin{array}{l}16 \text { Feb } \\
0000\end{array}$ & 3.01E-12 & $1.53 \mathrm{E}-11$ & 3.20E-12 & $1.50 \mathrm{E}-11$ & 4.38E-12 & $1.58 \mathrm{E}-11$ & 5.99E-12 & $2.80 \mathrm{E}-11$ & 5.60E-12 & 2.17E-11 \\
\hline $\begin{array}{l}16 \text { Feb } \\
0800\end{array}$ & 1.16E-11 & $4.02 \mathrm{E}-11$ & 1.11E-11 & 3.27E-11 & 1.15E-11 & 3.29E-11 & $1.54 \mathrm{E}-11$ & 4.60E-11 & $1.61 \mathrm{E}-11$ & 4.04E-11 \\
\hline $\begin{array}{l}17 \text { Feb } \\
0000\end{array}$ & 3.49E-12 & 1.30E-11 & 3.30E-12 & $1.22 \mathrm{E}-11$ & $5.62 \mathrm{E}-12$ & 1.46E-11 & 7.46E-12 & 2.73E-11 & 8.55E-12 & $2.44 \mathrm{E}-11$ \\
\hline $\begin{array}{l}17 \text { Feb } \\
0800\end{array}$ & $1.02 \mathrm{E}-11$ & 3.23E-11 & $8.12 \mathrm{E}-12$ & 2.71E-11 & 1.06E-11 & $2.78 \mathrm{E}-11$ & 1.68E-11 & 4.23E-11 & $1.52 \mathrm{E}-11$ & 3.31E-11 \\
\hline $\begin{array}{l}18 \text { Feb } \\
0000\end{array}$ & $3.82 \mathrm{E}-12$ & $1.86 \mathrm{E}-11$ & 3.96E-12 & 1.34E-11 & 4.71E-12 & $1.23 \mathrm{E}-11$ & $6.68 \mathrm{E}-12$ & $2.01 \mathrm{E}-11$ & $6.01 \mathrm{E}-12$ & $1.64 \mathrm{E}-11$ \\
\hline $\begin{array}{l}18 \text { Feb } \\
0800\end{array}$ & 4.61E-12 & $1.71 \mathrm{E}-11$ & 3.74E-12 & $1.60 \mathrm{E}-11$ & 4.83E-12 & $1.49 \mathrm{E}-11$ & $5.66 \mathrm{E}-12$ & $1.98 \mathrm{E}-11$ & 6.31E-12 & $1.87 \mathrm{E}-11$ \\
\hline $\begin{array}{l}19 \text { Feb } \\
0000\end{array}$ & 7.14E-13 & $2.34 \mathrm{E}-12$ & 7.23E-13 & 2.13E-12 & 8.80E-13 & $2.85 \mathrm{E}-12$ & $1.25 \mathrm{E}-12$ & 4.32E-12 & $1.27 \mathrm{E}-12$ & 3.38E-12 \\
\hline
\end{tabular}




\begin{tabular}{|c|c|c|c|c|c|c|c|c|c|c|}
\hline \multirow[b]{2}{*}{$\begin{array}{l}\text { Day / } \\
\text { hour }\end{array}$} & \multicolumn{2}{|c|}{$4 \mathrm{~Hz}$} & \multicolumn{2}{|c|}{$5 \mathrm{~Hz}$} & \multicolumn{2}{|c|}{$6 \mathrm{~Hz}$} & \multicolumn{2}{|c|}{$8 \mathrm{~Hz}$} & \multicolumn{2}{|c|}{$10 \mathrm{~Hz}$} \\
\hline & $\begin{array}{l}\text { Lower } \\
\text { Limit }\end{array}$ & $\begin{array}{l}\text { Upper } \\
\text { Limit }\end{array}$ & $\begin{array}{l}\text { Lower } \\
\text { Limit }\end{array}$ & $\begin{array}{l}\text { Upper } \\
\text { Limit }\end{array}$ & $\begin{array}{l}\text { Lower } \\
\text { Limit }\end{array}$ & $\begin{array}{l}\text { Upper } \\
\text { Limit }\end{array}$ & $\begin{array}{l}\text { Lower } \\
\text { Limit }\end{array}$ & $\begin{array}{l}\text { Upper } \\
\text { Limit }\end{array}$ & $\begin{array}{l}\text { Lower } \\
\text { Limit }\end{array}$ & $\begin{array}{l}\text { Upper } \\
\text { Limit }\end{array}$ \\
\hline $\begin{array}{l}19 \mathrm{Feb} \\
0800\end{array}$ & $1.24 \mathrm{E}-12$ & 7.83E-12 & $1.51 \mathrm{E}-12$ & $6.18 \mathrm{E}-12$ & $1.81 \mathrm{E}-12$ & $6.55 \mathrm{E}-12$ & $1.75 \mathrm{E}-12$ & 1.25E-11 & 2.08E-12 & 1.03E-11 \\
\hline $\begin{array}{l}20 \text { Feb } \\
0000\end{array}$ & $1.41 \mathrm{E}-12$ & 7.18E-12 & 1.69E-12 & $6.78 \mathrm{E}-12$ & $1.82 \mathrm{E}-12$ & $6.88 \mathrm{E}-12$ & 2.75E-12 & $9.11 \mathrm{E}-12$ & 2.61E-12 & 9.35E-12 \\
\hline $\begin{array}{l}20 \text { Feb } \\
0800\end{array}$ & $9.41 \mathrm{E}-12$ & 3.22E-11 & $8.52 \mathrm{E}-12$ & 2.93E-11 & $9.88 \mathrm{E}-12$ & $2.94 \mathrm{E}-11$ & $1.17 \mathrm{E}-11$ & 4.47E-11 & 1.23E-11 & 3.14E-11 \\
\hline $\begin{array}{l}21 \text { Feb } \\
0000\end{array}$ & $2.60 \mathrm{E}-12$ & $1.68 \mathrm{E}-11$ & $2.05 \mathrm{E}-12$ & 1.16E-11 & 3.94E-12 & $1.55 \mathrm{E}-11$ & $5.68 \mathrm{E}-12$ & $2.68 \mathrm{E}-11$ & 6.56E-12 & 2.37E-11 \\
\hline $\begin{array}{l}21 \text { Feb } \\
0800\end{array}$ & $1.21 \mathrm{E}-11$ & 3.38E-11 & 1.36E-11 & 3.78E-11 & $1.25 \mathrm{E}-11$ & 3.34E-11 & 1.70E-11 & 3.85E-11 & 1.50E-11 & 3.40E-11 \\
\hline
\end{tabular}

Table 17. Lower and upper limits of the principal portion of highway power PDFs by center frequency $(12.5 \mathrm{~Hz}-31.5 \mathrm{~Hz})$ for the hours of 0000 and 0800 on seven days, Wednesday, 15 February through Tuesday, 21 February 2006 . Vertical ground motion. Units: $\mathrm{m}^{2} / \mathrm{s}^{2}$.

\begin{tabular}{|c|c|c|c|c|c|c|c|c|c|c|}
\hline \multirow[b]{2}{*}{$\begin{array}{l}\text { Day / } \\
\text { hour }\end{array}$} & \multicolumn{2}{|c|}{$12.5 \mathrm{~Hz}$} & \multicolumn{2}{|c|}{$16 \mathrm{~Hz}$} & \multicolumn{2}{|c|}{$20 \mathrm{~Hz}$} & \multicolumn{2}{|c|}{$25 \mathrm{~Hz}$} & \multicolumn{2}{|c|}{$31.5 \mathrm{~Hz}$} \\
\hline & $\begin{array}{l}\text { Lower } \\
\text { Limit }\end{array}$ & $\begin{array}{l}\text { Upper } \\
\text { Limit }\end{array}$ & $\begin{array}{l}\text { Lower } \\
\text { Limit }\end{array}$ & $\begin{array}{l}\text { Upper } \\
\text { Limit }\end{array}$ & $\begin{array}{l}\text { Lower } \\
\text { Limit }\end{array}$ & $\begin{array}{l}\text { Upper } \\
\text { Limit }\end{array}$ & $\begin{array}{l}\text { Lower } \\
\text { Limit }\end{array}$ & $\begin{array}{l}\text { Upper } \\
\text { Limit }\end{array}$ & $\begin{array}{l}\text { Lower } \\
\text { Limit }\end{array}$ & $\begin{array}{l}\text { Upper } \\
\text { Limit }\end{array}$ \\
\hline $\begin{array}{l}15 \text { Feb } \\
0000\end{array}$ & 1.30E-11 & 3.16E-11 & 4.83E-11 & 1.11E-10 & $2.21 \mathrm{E}-10$ & 4.84E-10 & $1.34 \mathrm{E}-10$ & 3.08E-10 & $1.94 \mathrm{E}-10$ & 4.43E-10 \\
\hline $\begin{array}{l}15 \text { Feb } \\
0800\end{array}$ & 1.44E-11 & 4.87E-11 & 4.22E-11 & 9.59E-11 & $1.52 \mathrm{E}-10$ & 3.10E-10 & 1.17E-10 & $2.78 \mathrm{E}-10$ & $1.82 \mathrm{E}-10$ & 3.59E-10 \\
\hline $\begin{array}{l}\text { 16Feb } \\
0000\end{array}$ & 7.79E-12 & $2.50 \mathrm{E}-11$ & 2.99E-11 & $6.82 \mathrm{E}-11$ & 1.16E-10 & 3.17E-10 & 7.29E-11 & 1.77E-10 & $1.08 \mathrm{E}-10$ & $2.21 \mathrm{E}-10$ \\
\hline $\begin{array}{l}16 \text { Feb } \\
0800\end{array}$ & $1.72 \mathrm{E}-11$ & $4.29 \mathrm{E}-11$ & 4.49E-11 & $1.01 \mathrm{E}-10$ & $2.59 \mathrm{E}-10$ & $5.21 \mathrm{E}-10$ & $1.74 \mathrm{E}-10$ & $3.42 \mathrm{E}-10$ & 3.01E-10 & $5.74 \mathrm{E}-10$ \\
\hline $\begin{array}{l}17 \text { Feb } \\
0000\end{array}$ & $1.08 \mathrm{E}-11$ & $2.48 \mathrm{E}-11$ & 2.57E-11 & 5.38E-11 & 1.12E-10 & 2.43E-10 & 6.81E-11 & 1.64E-10 & 1.07E-10 & $2.57 \mathrm{E}-10$ \\
\hline $\begin{array}{l}17 \text { Feb } \\
0800\end{array}$ & $1.50 \mathrm{E}-11$ & $3.42 \mathrm{E}-11$ & 3.61E-11 & 7.67E-11 & $1.32 \mathrm{E}-10$ & 2.43E-10 & 7.84E-11 & $1.39 \mathrm{E}-10$ & $1.12 \mathrm{E}-10$ & $1.83 \mathrm{E}-10$ \\
\hline $\begin{array}{l}18 \text { Feb } \\
0000\end{array}$ & 8.14E-12 & 1.87E-11 & $1.98 \mathrm{E}-11$ & 4.61E-11 & $9.46 \mathrm{E}-11$ & $1.86 \mathrm{E}-10$ & 8.54E-11 & $1.68 \mathrm{E}-10$ & $1.29 \mathrm{E}-10$ & 2.41E-10 \\
\hline $\begin{array}{l}18 \text { Feb } \\
0800\end{array}$ & 6.34E-12 & 1.77E-11 & 1.20E-11 & 2.79E-11 & 5.34E-11 & $1.08 \mathrm{E}-10$ & 6.35E-11 & $1.23 \mathrm{E}-10$ & 8.50E-11 & 1.50E-10 \\
\hline $\begin{array}{l}19 \text { Feb } \\
0000\end{array}$ & $2.18 \mathrm{E}-12$ & 4.31E-12 & 4.75E-12 & $1.09 \mathrm{E}-11$ & $1.62 \mathrm{E}-11$ & 4.97E-11 & 2.14E-11 & 4.43E-11 & 3.43E-11 & $8.46 \mathrm{E}-11$ \\
\hline $\begin{array}{l}19 \text { Feb } \\
0800\end{array}$ & $2.88 \mathrm{E}-12$ & 8.35E-12 & 7.01E-12 & $1.42 \mathrm{E}-11$ & 2.53E-11 & $5.72 \mathrm{E}-11$ & 5.16E-11 & 8.32E-11 & 5.98E-11 & $1.14 \mathrm{E}-10$ \\
\hline $\begin{array}{l}20 \text { Feb } \\
0000\end{array}$ & 3.33E-12 & $9.50 \mathrm{E}-12$ & 5.30E-12 & 1.17E-11 & 1.47E-11 & 3.44E-11 & $1.78 \mathrm{E}-11$ & 3.40E-11 & $2.69 \mathrm{E}-11$ & 5.17E-11 \\
\hline $\begin{array}{l}20 \text { Feb } \\
0800\end{array}$ & $1.28 \mathrm{E}-11$ & $2.98 \mathrm{E}-11$ & 1.36E-11 & 3.00E-11 & 4.56E-11 & 8.79E-11 & 8.29E-11 & $1.34 \mathrm{E}-10$ & $7.85 \mathrm{E}-11$ & $1.22 \mathrm{E}-10$ \\
\hline $\begin{array}{l}21 \text { Feb } \\
0000\end{array}$ & $5.29 \mathrm{E}-12$ & $2.08 \mathrm{E}-11$ & $9.79 \mathrm{E}-12$ & $2.78 \mathrm{E}-11$ & $2.53 \mathrm{E}-11$ & $6.40 \mathrm{E}-11$ & $2.40 \mathrm{E}-11$ & 4.54E-11 & 3.38E-11 & 6.32E-11 \\
\hline $\begin{array}{l}21 \text { Feb } \\
0800\end{array}$ & 1.34E-11 & 2.99E-11 & 2.07E-11 & 4.16E-11 & 5.81E-11 & $1.18 \mathrm{E}-10$ & 1.14E-10 & $1.82 \mathrm{E}-10$ & $1.29 \mathrm{E}-10$ & $2.12 \mathrm{E}-10$ \\
\hline
\end{tabular}


Table 18. Lower and upper limits of the principal portion of highway power PDFs by center frequency $(40 \mathrm{~Hz}-80 \mathrm{~Hz})$ for the hours of 0000 and 0800 on seven days, Wednesday, 15

February through Tuesday, 21 February 2006. Vertical ground motion. Units: $\mathrm{m}^{2} / \mathrm{s}^{2}$.

\begin{tabular}{|c|c|c|c|c|c|c|c|c|}
\hline \multirow[b]{2}{*}{$\begin{array}{l}\text { Day / } \\
\text { hour }\end{array}$} & \multicolumn{2}{|c|}{$40 \mathrm{~Hz}$} & \multicolumn{2}{|c|}{$50 \mathrm{~Hz}$} & \multicolumn{2}{|c|}{$63 \mathrm{~Hz}$} & \multicolumn{2}{|c|}{$80 \mathrm{~Hz}$} \\
\hline & $\begin{array}{l}\text { Lower } \\
\text { Limit }\end{array}$ & $\begin{array}{l}\text { Upper } \\
\text { Limit }\end{array}$ & $\begin{array}{l}\text { Lower } \\
\text { Limit }\end{array}$ & $\begin{array}{l}\text { Upper } \\
\text { Limit }\end{array}$ & $\begin{array}{l}\text { Lower } \\
\text { Limit }\end{array}$ & $\begin{array}{l}\text { Upper } \\
\text { Limit }\end{array}$ & $\begin{array}{l}\text { Lower } \\
\text { Limit }\end{array}$ & $\begin{array}{l}\text { Upper } \\
\text { Limit }\end{array}$ \\
\hline $\begin{array}{l}15 \mathrm{Feb} \\
0000\end{array}$ & 5.69E-11 & 1.31E-10 & 3.67E-11 & 5.96E-11 & 3.30E-11 & 4.60E-11 & 3.29E-11 & 4.16E-11 \\
\hline $\begin{array}{l}15 \text { Feb } \\
0800\end{array}$ & 9.97E-11 & 2.25E-10 & 4.95E-11 & $9.71 \mathrm{E}-11$ & 3.10E-11 & 4.19E-11 & 3.16E-11 & 3.86E-11 \\
\hline $\begin{array}{l}16 \text { Feb } \\
0000\end{array}$ & 5.48E-11 & 1.23E-10 & 2.95E-11 & 4.90E-11 & 9.66E-11 & $1.98 \mathrm{E}-10$ & $1.26 \mathrm{E}-10$ & $1.98 \mathrm{E}-10$ \\
\hline $\begin{array}{l}16 \text { Feb } \\
0800\end{array}$ & 1.26E-10 & 2.63E-10 & 4.44E-11 & 7.14E-11 & 3.25E-11 & 4.43E-11 & 3.14E-11 & 4.06E-11 \\
\hline $\begin{array}{l}17 \text { Feb } \\
0000\end{array}$ & 4.77E-11 & $9.58 \mathrm{E}-11$ & 3.05E-11 & 5.10E-11 & 2.98E-11 & 4.35E-11 & 3.03E-11 & 4.01E-11 \\
\hline $\begin{array}{l}17 \text { Feb } \\
0800\end{array}$ & $6.50 \mathrm{E}-11$ & $1.28 \mathrm{E}-10$ & 3.04E-11 & 4.49E-11 & $2.84 \mathrm{E}-11$ & 3.79E-11 & 3.02E-11 & 3.86E-11 \\
\hline $\begin{array}{l}18 \text { Feb } \\
0000\end{array}$ & 5.34E-11 & $1.26 \mathrm{E}-10$ & $2.59 \mathrm{E}-11$ & 4.10E-11 & 2.79E-11 & 3.91E-11 & $2.97 \mathrm{E}-11$ & $3.90 \mathrm{E}-11$ \\
\hline $\begin{array}{l}18 \mathrm{Feb} \\
0800\end{array}$ & 5.51E-11 & $1.02 \mathrm{E}-10$ & 3.04E-11 & 4.55E-11 & 3.00E-11 & 3.97E-11 & 3.18E-11 & 4.06E-11 \\
\hline $\begin{array}{l}19 \text { Feb } \\
0000\end{array}$ & $2.28 \mathrm{E}-11$ & 4.61E-11 & $2.50 \mathrm{E}-11$ & 3.37E-11 & 3.09E-11 & $3.84 \mathrm{E}-11$ & 3.36E-11 & $4.09 \mathrm{E}-11$ \\
\hline $\begin{array}{l}19 \text { Feb } \\
0800\end{array}$ & 3.50E-11 & 5.69E-11 & 2.62E-11 & 3.70E-11 & $2.78 \mathrm{E}-11$ & 3.39E-11 & $2.95 \mathrm{E}-11$ & 3.49E-11 \\
\hline $\begin{array}{l}20 \text { Feb } \\
0000\end{array}$ & $1.91 \mathrm{E}-11$ & 3.09E-11 & $2.40 \mathrm{E}-11$ & 3.23E-11 & $2.87 \mathrm{E}-11$ & 3.66E-11 & $3.08 \mathrm{E}-11$ & 3.93E-11 \\
\hline $\begin{array}{l}20 \text { Feb } \\
0800\end{array}$ & 4.32E-11 & $6.83 \mathrm{E}-11$ & 3.18E-11 & $4.52 \mathrm{E}-11$ & 3.24E-11 & 4.38E-11 & 3.43E-11 & 4.36E-11 \\
\hline $\begin{array}{l}21 \text { Feb } \\
0000\end{array}$ & $2.45 \mathrm{E}-11$ & 4.60E-11 & $2.50 \mathrm{E}-11$ & 3.35E-11 & $2.95 \mathrm{E}-11$ & 3.95E-11 & 3.32E-11 & 4.25E-11 \\
\hline $\begin{array}{l}21 \text { Feb } \\
0800\end{array}$ & 8.08E-11 & $1.34 \mathrm{E}-10$ & 4.75E-11 & $6.83 \mathrm{E}-11$ & 3.83E-11 & $5.22 \mathrm{E}-11$ & $3.65 \mathrm{E}-11$ & $4.58 \mathrm{E}-11$ \\
\hline
\end{tabular}



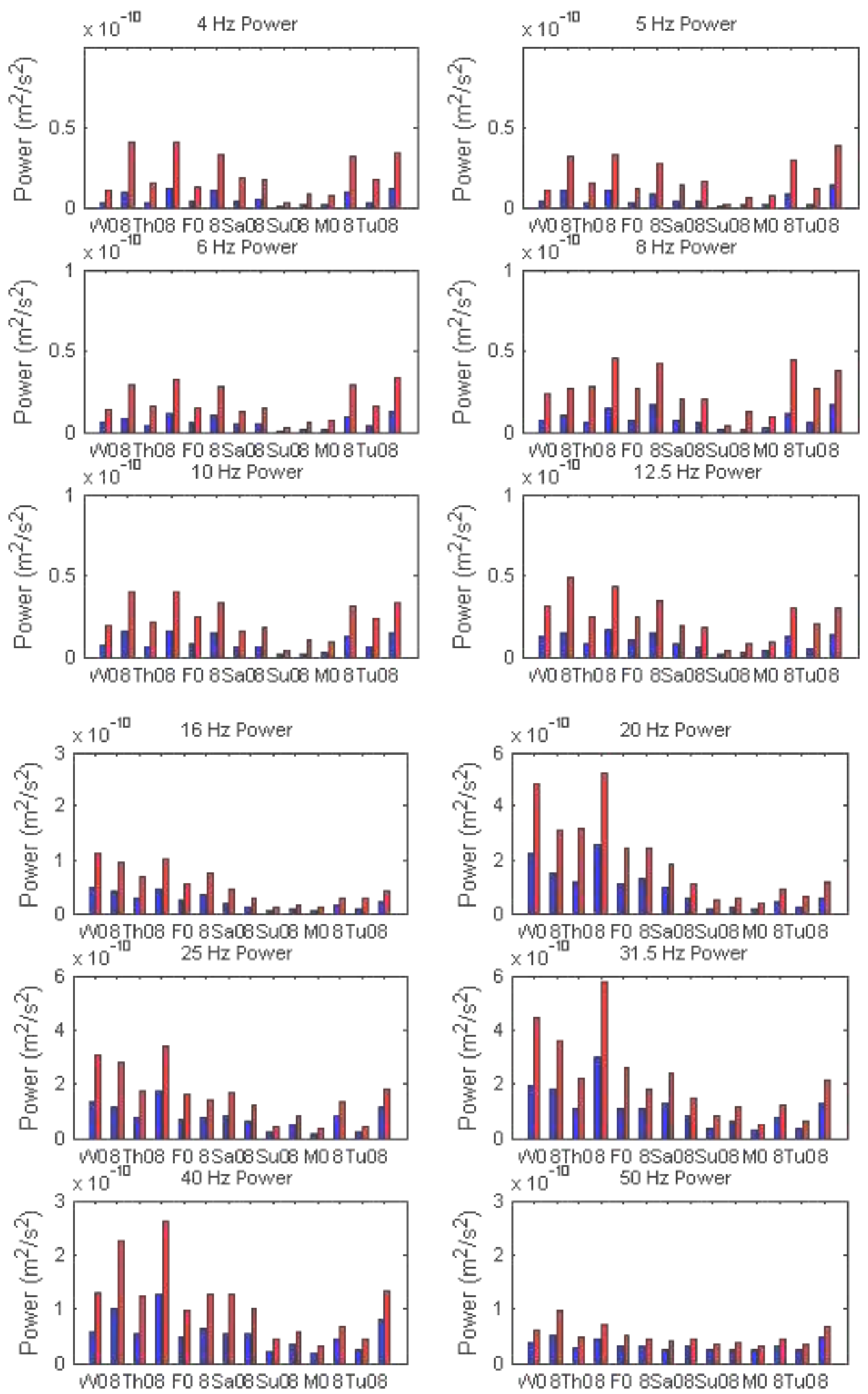

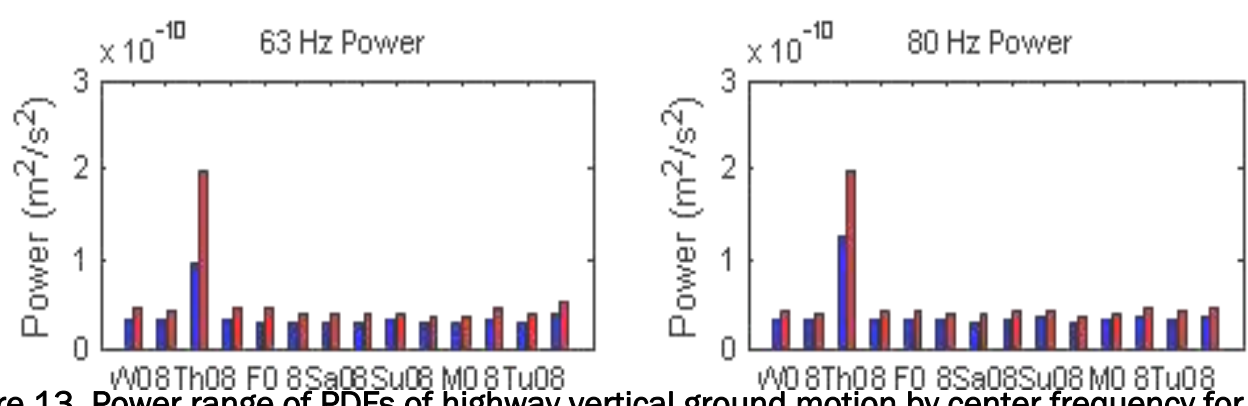

Figure 13. Power range of PDFs of highway vertical ground motion by center frequency for the hours $0000-0100$ and $0800-0900$ on seven days, Wednesday, 15 February 2006, through Tuesday, 21 February 2006. The blue (red) bar indicates the selected lower (upper) limit of the principal portion of each power PDF. X-axis designations are 0 or 8 for 0000 or 0800 , respectively, and W, Th, F, Sa, Su, M, and Tu for Wednesday, Thursday, Friday, Saturday, Sunday, Monday, and Tuesday, respectively. The y-axis upper limit is 1, 3, or 6 × 10-10, depending on the center frequency.

\subsubsection{Orientation variation}

The variation in highway ground motion by orientation is shown with $4 \mathrm{~Hz}$ PDFs for the hours 0000 and 0800 on Wednesday, 15 February and Sunday, 19 February 2006 (Figure 14). [Similar PDF plots for east-west and north-south ground motion at the other frequencies are included on the accompanying CD.] For all orientations, Sunday (19 February) ground motion is weaker than Wednesday (15 February) ground motion at the same hour. Horizontal ground motion is stronger than vertical ground motion. Assuming that traffic is the primary ground motion source, then the horizontal motion being stronger suggests that lateral loading of the pavement by the rolling tires is a more significant influence on seismic noise at this site than is vertical loading due to tires bumping over pavement surface irregularities.

A power range with each hour's PDF was determined by visual inspection of the plots. The upper and lower limits of the power range are not the extreme limits of the PDF; rather, they are a subjective determination of the principal portion of a PDF range, excluding low amplitude oscillatory tails. The selected limits were tabulated for each center frequency (Tables 19-21) and plotted (Figure 15). Below $20 \mathrm{~Hz}$, horizontal ground motion is stronger, although whether the north-south or east-west component dominates is variable. At 20 to $50 \mathrm{~Hz}$, vertical ground motion is stronger and the Wednesday/ Sunday difference in ground motion strength persists. At 63 and $80 \mathrm{~Hz}$, the seismic noise is indistinguishable by orientation, day of the week, or hour of the day. 
a

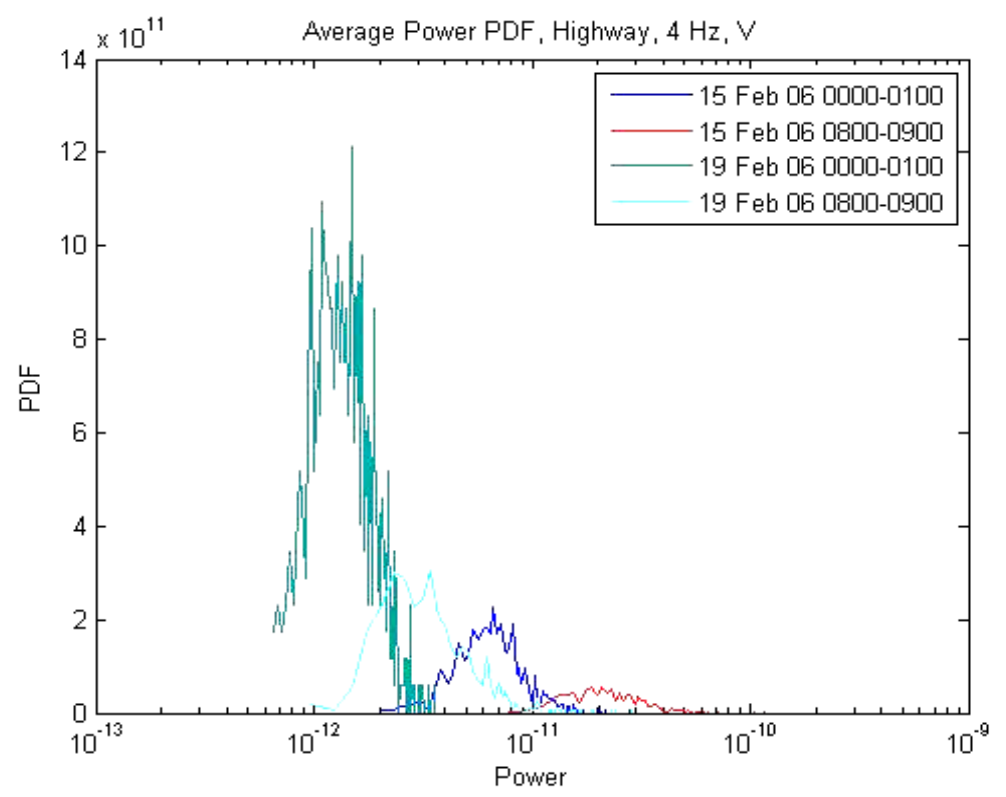

b

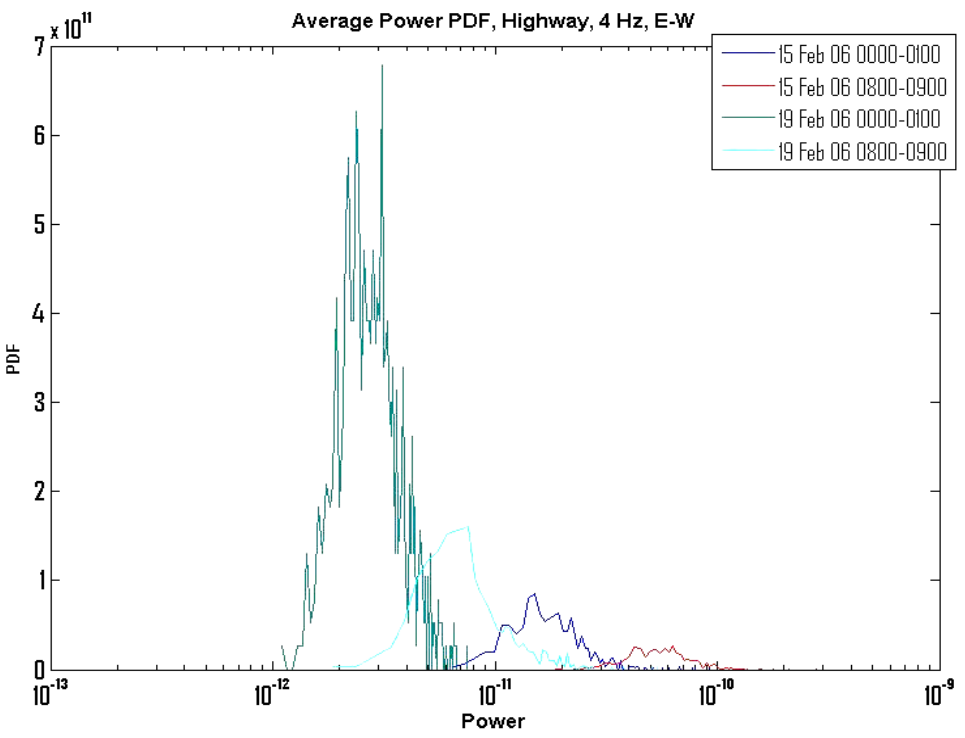




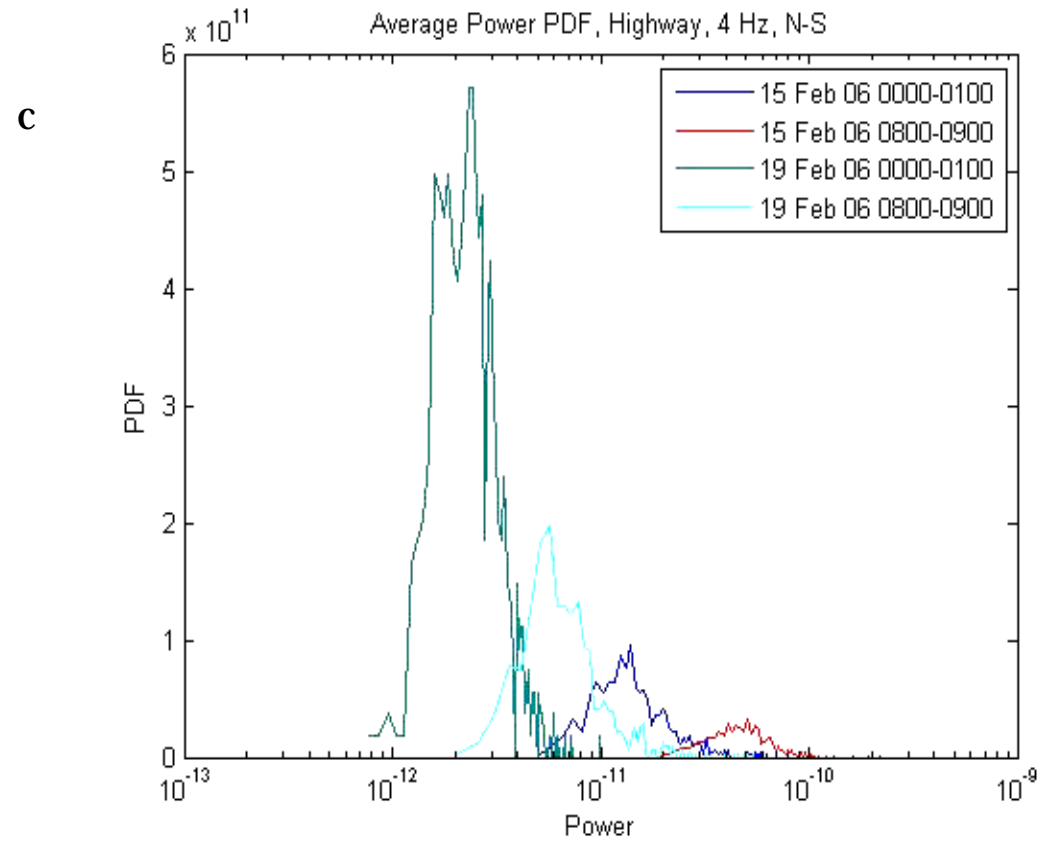

Figure 14. Power PDFs at $4 \mathrm{~Hz}$ center frequency for ground motion at the highway site on two days, Wednesday, 15 February and Sunday, 19 February 2006, during the hours of 0000 0100 and 0800 - 0900. (a) Vertical ground motion, (b) east-west horizontal ground motion, (c) north-south horizontal ground motion. 
Table 19. Lower and upper limits of the principal portion of highway power PDFs by center frequency $(4 \mathrm{~Hz}-10 \mathrm{~Hz})$ for the hours of 0000 and 0800 on Wednesday, 15 February and Sunday, 19 February 2006. Vertical (V), east-west horizontal (E-W) and north-south (N-S) horizontal ground motion. Units: $\mathrm{m}^{2} / \mathrm{s}^{2}$

\begin{tabular}{|c|c|c|c|c|c|c|c|c|c|c|}
\hline \multirow[b]{2}{*}{$\begin{array}{l}\text { Orientation / } \\
\text { date/ hour }\end{array}$} & \multicolumn{2}{|c|}{$4 \mathrm{~Hz}$} & \multicolumn{2}{|c|}{$5 \mathrm{~Hz}$} & \multicolumn{2}{|c|}{$6 \mathrm{~Hz}$} & \multicolumn{2}{|c|}{$8 \mathrm{~Hz}$} & \multicolumn{2}{|c|}{$10 \mathrm{~Hz}$} \\
\hline & $\begin{array}{l}\text { Lower } \\
\text { Limit }\end{array}$ & $\begin{array}{l}\text { Upper } \\
\text { Limit }\end{array}$ & $\begin{array}{l}\text { Lower } \\
\text { Limit }\end{array}$ & $\begin{array}{l}\text { Upper } \\
\text { Limit }\end{array}$ & $\begin{array}{l}\text { Lower } \\
\text { Limit }\end{array}$ & $\begin{array}{l}\text { Upper } \\
\text { Limit }\end{array}$ & $\begin{array}{l}\text { Lower } \\
\text { Limit }\end{array}$ & $\begin{array}{l}\text { Upper } \\
\text { Limit }\end{array}$ & $\begin{array}{l}\text { Lower } \\
\text { Limit }\end{array}$ & $\begin{array}{l}\text { Upper } \\
\text { Limit }\end{array}$ \\
\hline V 15 Feb 0000 & 3.33E-12 & $1.08 \mathrm{E}-11$ & 3.75E-12 & $1.08 \mathrm{E}-11$ & $5.78 \mathrm{E}-12$ & $1.38 \mathrm{E}-11$ & $7.22 \mathrm{E}-12$ & 2.32E-11 & 7.17E-12 & 1.93E-11 \\
\hline V 15 Feb 0800 & 8.99E-12 & 4.05E-11 & $1.04 \mathrm{E}-11$ & $3.21 \mathrm{E}-11$ & $8.74 \mathrm{E}-12$ & 2.95E-11 & 1.03E-11 & $2.71 \mathrm{E}-11$ & $1.64 \mathrm{E}-11$ & 3.97E-11 \\
\hline $\begin{array}{l}\text { E-W } 15 \text { Feb } \\
0000\end{array}$ & $7.28 \mathrm{E}-12$ & 3.23E-11 & $9.61 \mathrm{E}-12$ & $3.88 \mathrm{E}-11$ & $3.53 \mathrm{E}-11$ & $1.07 \mathrm{E}-10$ & 4.56E-11 & $1.35 \mathrm{E}-10$ & 3.84E-11 & $1.11 \mathrm{E}-10$ \\
\hline $\begin{array}{l}\text { E-W } 15 \text { Feb } \\
0800\end{array}$ & $2.66 \mathrm{E}-11$ & $9.98 \mathrm{E}-11$ & 3.49E-11 & $9.82 \mathrm{E}-11$ & 4.89E-11 & $2.66 \mathrm{E}-10$ & $5.56 \mathrm{E}-11$ & $1.86 \mathrm{E}-10$ & $8.45 \mathrm{E}-11$ & $2.19 \mathrm{E}-10$ \\
\hline $\begin{array}{l}\text { N-S } 15 \text { Feb } \\
0000\end{array}$ & $5.14 \mathrm{E}-12$ & $2.81 \mathrm{E}-11$ & 8.25E-12 & 2.77E-11 & $1.86 \mathrm{E}-11$ & $4.78 \mathrm{E}-11$ & 3.62E-11 & $1.06 \mathrm{E}-10$ & $4.02 \mathrm{E}-11$ & $9.68 \mathrm{E}-11$ \\
\hline $\begin{array}{l}\text { N-S } 15 \text { Feb } \\
0800\end{array}$ & $1.90 \mathrm{E}-11$ & $8.52 E-11$ & $2.70 \mathrm{E}-11$ & 8.14E-11 & 3.13E-11 & $9.07 \mathrm{E}-11$ & $5.44 \mathrm{E}-11$ & $1.29 \mathrm{E}-10$ & 8.01E-11 & $1.95 \mathrm{E}-10$ \\
\hline V 19 Feb 0000 & $7.14 \mathrm{E}-13$ & 2.34E-12 & 7.23E-13 & $2.13 \mathrm{E}-12$ & $8.80 \mathrm{E}-13$ & $2.85 \mathrm{E}-12$ & $1.25 \mathrm{E}-12$ & 4.32E-12 & $1.27 \mathrm{E}-12$ & $3.38 \mathrm{E}-12$ \\
\hline V 19 Feb 0800 & $1.24 \mathrm{E}-12$ & $7.83 \mathrm{E}-12$ & $1.51 \mathrm{E}-12$ & $6.18 \mathrm{E}-12$ & $1.81 \mathrm{E}-12$ & $6.55 E-12$ & $1.75 \mathrm{E}-12$ & $1.25 \mathrm{E}-11$ & $2.08 \mathrm{E}-12$ & 1.03E-11 \\
\hline $\begin{array}{l}\text { E-W } 19 \text { Feb } \\
0000\end{array}$ & 1.36E-12 & 4.76E-12 & $1.89 \mathrm{E}-12$ & $6.09 \mathrm{E}-12$ & 4.03E-12 & $1.95 \mathrm{E}-11$ & 4.49E-12 & 3.06E-11 & 3.67E-12 & $1.98 \mathrm{E}-11$ \\
\hline $\begin{array}{l}\text { E-W } 19 \text { Feb } \\
0800\end{array}$ & $2.37 \mathrm{E}-12$ & 1.49E-11 & $2.90 \mathrm{E}-12$ & 1.99E-11 & $9.36 \mathrm{E}-12$ & 7.96E-11 & $8.16 \mathrm{E}-12$ & $8.20 \mathrm{E}-11$ & 8.84E-12 & 7.19E-11 \\
\hline $\begin{array}{l}\text { N-S } 19 \text { Feb } \\
0000\end{array}$ & 1.14E-12 & 3.87E-12 & $1.78 \mathrm{E}-12$ & 4.96E-12 & $2.85 \mathrm{E}-12$ & 8.91E-12 & $3.99 \mathrm{E}-12$ & 2.03E-11 & 3.76E-12 & $1.61 \mathrm{E}-11$ \\
\hline $\begin{array}{l}\text { N-S } 19 \text { Feb } \\
0800\end{array}$ & 2.05E-12 & $1.30 \mathrm{E}-11$ & 3.71E-12 & $1.56 \mathrm{E}-11$ & 4.24E-12 & $2.55 \mathrm{E}-11$ & 7.16E-12 & 7.37E-11 & $7.82 \mathrm{E}-12$ & 5.80E-11 \\
\hline
\end{tabular}


Table 20. Lower and upper limits of the principal portion of highway power PDFs by center frequency $(12.5 \mathrm{~Hz}-31.5 \mathrm{~Hz})$ for the hours of 0000 and 0800 on Wednesday, 15 February and Sunday, 19 February 2006. Vertical (V), east-west horizontal (E-W) and north-south (N-S) horizontal ground motion. Units: $\mathrm{m}^{2} / \mathrm{s}^{2}$.

\begin{tabular}{|c|c|c|c|c|c|c|c|c|c|c|}
\hline \multirow{2}{*}{$\begin{array}{l}\text { Orientation } \\
\text { / date/ } \\
\text { hour }\end{array}$} & \multicolumn{2}{|c|}{$12.5 \mathrm{~Hz}$} & \multicolumn{2}{|c|}{$16 \mathrm{~Hz}$} & \multicolumn{2}{|c|}{$20 \mathrm{~Hz}$} & \multicolumn{2}{|c|}{$25 \mathrm{~Hz}$} & \multicolumn{2}{|c|}{$31.5 \mathrm{~Hz}$} \\
\hline & $\begin{array}{l}\text { Lower } \\
\text { Limit }\end{array}$ & $\begin{array}{l}\text { Upper } \\
\text { Limit }\end{array}$ & $\begin{array}{l}\text { Lower } \\
\text { Limit }\end{array}$ & $\begin{array}{l}\text { Upper } \\
\text { Limit }\end{array}$ & $\begin{array}{l}\text { Lower } \\
\text { Limit }\end{array}$ & $\begin{array}{l}\text { Upper } \\
\text { Limit }\end{array}$ & $\begin{array}{l}\text { Lower } \\
\text { Limit }\end{array}$ & $\begin{array}{l}\text { Upper } \\
\text { Limit }\end{array}$ & $\begin{array}{l}\text { Lower } \\
\text { Limit }\end{array}$ & $\begin{array}{l}\text { Upper } \\
\text { Limit }\end{array}$ \\
\hline $\begin{array}{l}\text { V } 15 \text { Feb } \\
0000\end{array}$ & 1.30E-11 & 3.16E-11 & 4.83E-11 & $1.11 \mathrm{E}-10$ & $2.21 \mathrm{E}-10$ & $4.84 \mathrm{E}-10$ & $1.34 \mathrm{E}-10$ & $3.08 \mathrm{E}-10$ & $1.94 \mathrm{E}-10$ & 4.43E-10 \\
\hline $\begin{array}{l}\text { V } 15 \text { Feb } \\
0800\end{array}$ & $1.44 \mathrm{E}-11$ & 4.87E-11 & $4.22 \mathrm{E}-11$ & $9.59 \mathrm{E}-11$ & $1.52 \mathrm{E}-10$ & $3.10 \mathrm{E}-10$ & $1.17 \mathrm{E}-10$ & $2.78 \mathrm{E}-10$ & $1.82 \mathrm{E}-10$ & $3.59 \mathrm{E}-10$ \\
\hline $\begin{array}{l}\text { E-W } 15 \text { Feb } \\
0000\end{array}$ & $3.76 \mathrm{E}-11$ & 8.06E-11 & 3.25E-11 & $7.50 \mathrm{E}-11$ & 4.93E-11 & $1.24 \mathrm{E}-10$ & 4.73E-11 & $1.01 \mathrm{E}-10$ & $2.10 \mathrm{E}-11$ & 4.09E-11 \\
\hline $\begin{array}{l}\text { E-W } 15 \text { Feb } \\
0800\end{array}$ & 4.41E-11 & $1.16 \mathrm{E}-10$ & 2.15E-11 & 4.99E-11 & $2.71 \mathrm{E}-11$ & $7.02 \mathrm{E}-11$ & $4.56 \mathrm{E}-11$ & $9.04 \mathrm{E}-11$ & $2.24 \mathrm{E}-11$ & 3.99E-11 \\
\hline $\begin{array}{l}\text { N-S } 15 \text { Feb } \\
0000\end{array}$ & $5.66 \mathrm{E}-11$ & $1.33 \mathrm{E}-10$ & 1.19E-10 & $3.07 \mathrm{E}-10$ & $1.49 \mathrm{E}-10$ & 3.79E-10 & $4.78 \mathrm{E}-11$ & $1.15 \mathrm{E}-10$ & $3.91 \mathrm{E}-11$ & 8.44E-11 \\
\hline $\begin{array}{l}\text { N-S } 15 \text { Feb } \\
0800\end{array}$ & $6.51 \mathrm{E}-11$ & $1.61 \mathrm{E}-10$ & $6.93 \mathrm{E}-11$ & $1.73 \mathrm{E}-10$ & $8.91 \mathrm{E}-11$ & $2.12 \mathrm{E}-10$ & $6.59 \mathrm{E}-11$ & $1.27 \mathrm{E}-10$ & $3.89 \mathrm{E}-11$ & 7.06E-11 \\
\hline $\begin{array}{l}\text { V } 19 \text { Feb } \\
0000\end{array}$ & $2.18 \mathrm{E}-12$ & 4.31E-12 & 4.75E-12 & $1.09 \mathrm{E}-11$ & $1.62 \mathrm{E}-11$ & 4.97E-11 & 2.14E-11 & 4.43E-11 & 3.43E-11 & 8.46E-11 \\
\hline $\begin{array}{l}\text { V } 19 \text { Feb } \\
0800\end{array}$ & $2.88 \mathrm{E}-12$ & 8.35E-12 & 7.01E-12 & $1.42 \mathrm{E}-11$ & $2.53 \mathrm{E}-11$ & $5.72 \mathrm{E}-11$ & $5.16 \mathrm{E}-11$ & 8.32E-11 & $5.98 \mathrm{E}-11$ & $1.14 \mathrm{E}-10$ \\
\hline $\begin{array}{l}\text { E-W } 19 \text { Feb } \\
0000\end{array}$ & 4.38E-12 & $1.37 \mathrm{E}-11$ & $5.27 \mathrm{E}-12$ & $1.27 \mathrm{E}-11$ & 8.75E-12 & $1.97 \mathrm{E}-11$ & $1.00 \mathrm{E}-11$ & $2.04 \mathrm{E}-11$ & 1.13E-11 & 2.32E-11 \\
\hline $\begin{array}{l}\text { E-W } 19 \text { Feb } \\
0800\end{array}$ & 7.61E-12 & 4.03E-11 & 7.63E-12 & 1.93E-11 & $1.42 \mathrm{E}-11$ & 3.13E-11 & $2.00 \mathrm{E}-11$ & 3.30E-11 & $1.46 \mathrm{E}-11$ & $2.44 \mathrm{E}-11$ \\
\hline $\begin{array}{l}\text { N-S } 19 \text { Feb } \\
0000\end{array}$ & 5.47E-12 & $2.02 \mathrm{E}-11$ & $1.01 \mathrm{E}-11$ & $3.83 E-11$ & $1.34 \mathrm{E}-11$ & $5.03 E-11$ & 1.14E-11 & $2.60 \mathrm{E}-11$ & 1.33E-11 & 2.83E-11 \\
\hline $\begin{array}{l}\text { N-S } 19 \text { Feb } \\
0800\end{array}$ & $9.02 \mathrm{E}-12$ & 4.47E-11 & $1.54 \mathrm{E}-11$ & $4.87 \mathrm{E}-11$ & 2.69E-11 & $6.30 \mathrm{E}-11$ & $2.23 \mathrm{E}-11$ & 4.34E-11 & $1.84 \mathrm{E}-11$ & 3.67E-11 \\
\hline
\end{tabular}


Table 21. Lower and upper limits of the principal portion of highway power PDFs by center frequency $(40 \mathrm{~Hz}-80 \mathrm{~Hz})$ for the hours of 0000 and 0800 on Wednesday, 15 February and Sunday, 19 February 2006. Vertical (V), east-west horizontal (E-W) and north-south (N-S) horizontal ground motion. Units: $\mathrm{m}^{2} / \mathrm{s}^{2}$.

\begin{tabular}{|c|c|c|c|c|c|c|c|c|}
\hline \multirow{2}{*}{$\begin{array}{l}\text { Orientation } \\
\text { / date/ } \\
\text { hour }\end{array}$} & \multicolumn{2}{|c|}{$40 \mathrm{~Hz}$} & \multicolumn{2}{|c|}{$50 \mathrm{~Hz}$} & \multicolumn{2}{|c|}{$63 \mathrm{~Hz}$} & \multicolumn{2}{|c|}{$80 \mathrm{~Hz}$} \\
\hline & $\begin{array}{l}\text { Lower } \\
\text { Limit }\end{array}$ & $\begin{array}{l}\text { Upper } \\
\text { Limit }\end{array}$ & $\begin{array}{l}\text { Lower } \\
\text { Limit }\end{array}$ & $\begin{array}{l}\text { Upper } \\
\text { Limit }\end{array}$ & $\begin{array}{l}\text { Lower } \\
\text { Limit }\end{array}$ & $\begin{array}{l}\text { Upper } \\
\text { Limit }\end{array}$ & $\begin{array}{l}\text { Lower } \\
\text { Limit }\end{array}$ & $\begin{array}{l}\text { Upper } \\
\text { Limit }\end{array}$ \\
\hline $\begin{array}{l}\text { V } 15 \text { Feb } \\
0000\end{array}$ & 5.69E-11 & $1.31 \mathrm{E}-10$ & 3.67E-11 & 5.96E-11 & 3.30E-11 & 4.60E-11 & 3.29E-11 & 4.16E-11 \\
\hline $\begin{array}{l}\text { V } 15 \text { Feb } \\
0800\end{array}$ & 9.97E-11 & $2.25 \mathrm{E}-10$ & 4.95E-11 & 9.71E-11 & 3.10E-11 & 4.19E-11 & 3.16E-11 & 3.86E-11 \\
\hline $\begin{array}{l}\text { E-W } 15 \text { Feb } \\
0000\end{array}$ & $1.52 \mathrm{E}-11$ & $2.72 \mathrm{E}-11$ & $1.81 \mathrm{E}-11$ & 2.92E-11 & 2.43E-11 & 3.66E-11 & 2.54E-11 & $3.25 \mathrm{E}-11$ \\
\hline $\begin{array}{l}\text { E-W } 15 \text { Feb } \\
0800\end{array}$ & 1.81E-11 & 2.87E-11 & $2.14 \mathrm{E}-11$ & 3.27E-11 & 2.46E-11 & $3.52 \mathrm{E}-11$ & 2.51E-11 & 3.34E-11 \\
\hline $\begin{array}{l}\text { N-S } 15 \text { Feb } \\
0000\end{array}$ & 1.16E-11 & 1.99E-11 & 1.19E-11 & 2.19E-11 & 2.00E-11 & 3.45E-11 & $2.48 \mathrm{E}-11$ & 3.19E-11 \\
\hline $\begin{array}{l}\text { N-S } 15 \text { Feb } \\
0800\end{array}$ & $1.81 \mathrm{E}-11$ & 3.26E-11 & $1.56 \mathrm{E}-11$ & 2.64E-11 & 2.16E-11 & 3.15E-11 & $2.54 \mathrm{E}-11$ & 3.30E-11 \\
\hline $\begin{array}{l}\text { V } 19 \text { Feb } \\
0000\end{array}$ & $2.28 \mathrm{E}-11$ & 4.61E-11 & $2.50 \mathrm{E}-11$ & 3.37E-11 & 3.09E-11 & 3.84E-11 & 3.36E-11 & 4.09E-11 \\
\hline $\begin{array}{l}\text { V } 19 \text { Feb } \\
0800\end{array}$ & 3.50E-11 & 5.69E-11 & 2.62E-11 & 3.70E-11 & $2.78 \mathrm{E}-11$ & 3.39E-11 & 2.95E-11 & 3.49E-11 \\
\hline $\begin{array}{l}\text { E-W } 19 \text { Feb } \\
0000\end{array}$ & 1.50E-11 & $2.84 \mathrm{E}-11$ & 2.00E-11 & 3.16E-11 & $2.82 \mathrm{E}-11$ & 3.93E-11 & 2.66E-11 & 4.06E-11 \\
\hline $\begin{array}{l}\text { E-W } 19 \text { Feb } \\
0800\end{array}$ & $1.41 \mathrm{E}-11$ & 2.31E-11 & $1.68 \mathrm{E}-11$ & 2.42E-11 & $2.53 E-11$ & 3.40E-11 & $2.43 \mathrm{E}-11$ & 3.04E-11 \\
\hline $\begin{array}{l}\text { N-S } 19 \text { Feb } \\
0000\end{array}$ & $1.24 \mathrm{E}-11$ & $2.62 \mathrm{E}-11$ & $1.57 \mathrm{E}-11$ & $2.47 \mathrm{E}-11$ & $2.49 \mathrm{E}-11$ & $3.48 \mathrm{E}-11$ & 2.66E-11 & 4.33E-11 \\
\hline $\begin{array}{l}\text { N-S } 19 \text { Feb } \\
0800\end{array}$ & 1.13E-11 & $2.10 \mathrm{E}-11$ & $1.39 \mathrm{E}-11$ & $2.26 \mathrm{E}-11$ & 3.61E-11 & $4.85 \mathrm{E}-11$ & 2.28E-11 & $2.82 \mathrm{E}-11$ \\
\hline
\end{tabular}



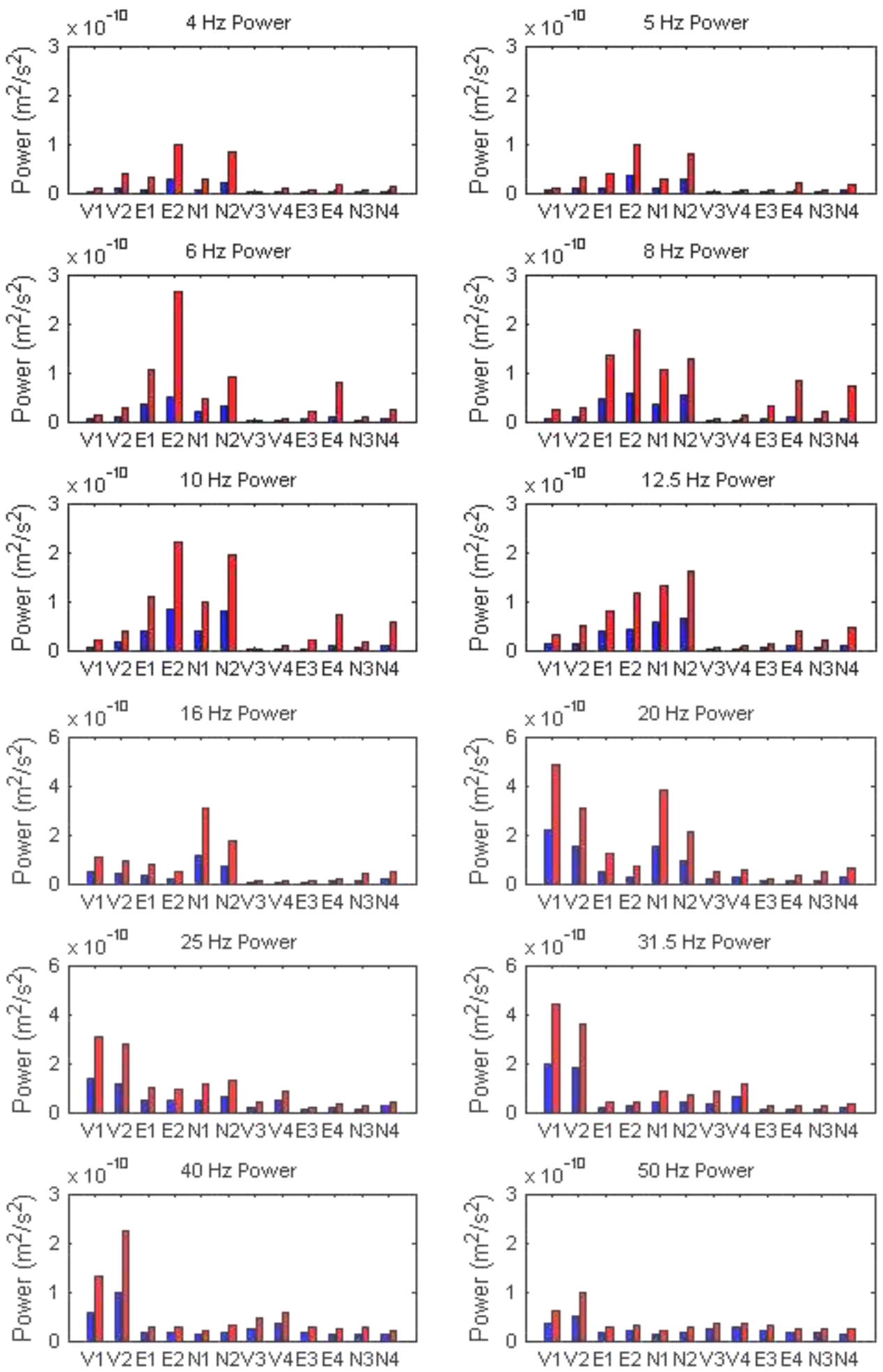

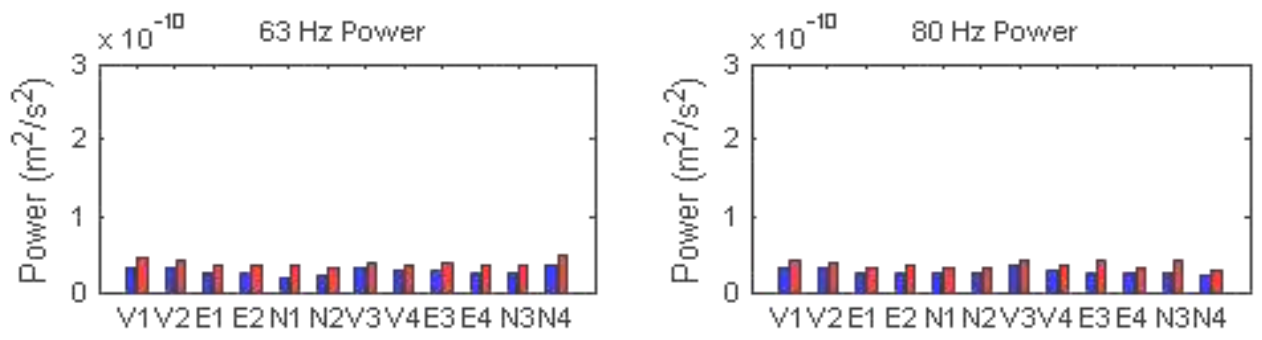

Figure 15. Power range of PDFs of highway ground motion by orientation, day, hour, and center frequency. The blue (red) bar indicates the selected lower (upper) limit of the principal portion of each power PDF. On the $x$ axis, $V$ denotes the vertical component of ground motion, $\mathrm{E}$ denotes the east-west component, and $\mathrm{N}$ denotes north-south; 1 denotes the 0000 hour on Wednesday, 15 February 2006; 2 denotes the $0800 \mathrm{hr}$ on that day; 3 denotes the $0000 \mathrm{hr}$ on Sunday, 19 February 2006; 4 denotes the $0800 \mathrm{hr}$ on that day. The y-axis upper limit is 3 or $6 \times 10^{-10}$, depending on center frequency. 


\section{$5 \quad$ Curve Fitting}

Polynomials of degree three through nine were fit to each site's hourly PDFs using the MatLab function, polyfit. Fitted curves were generated for each center frequency and, for the wind farm and highway sites, for each ground motion orientation. Files containing the polynomial coefficients, as well as parameters comparing a PDF with its fitted curve, are included on the accompanying $\mathrm{CD}$.

To facilitate the comparison of seismic noise among the sites as a function of center frequency, composite plots of curves generated with the ninth degree polynomial coefficients are shown in Figure 16. The curves are calculated for values of power defined by the lower and upper limits presented in Tables 2-4, 6-9, 10-12, and 13-15 for the wind farm, Enfield, highway - 15 Feb 06 and highway - 19 Feb 06 PDFs, respectively. The Enfield curves correspond to the hours 0000 - 0100 and 0700 - 0800 (0400 - 0500 and 1100 - 1200 GMT); the highway plots correspond to the hours 0000 - 0100 and 0800 - 0900 on Wednesday, 15 February and Sunday, 19 February. Wind farm curves are included for center frequencies of 4 - 40 $\mathrm{Hz}$; the upper limit is determined by the $100-\mathrm{Hz}$ sampling frequency.

The plots highlight that the Enfield ground motion is strongest at all frequencies. A contributing factor was that the Enfield geophones were located at the ground surface, with only the geophone spike embedded in the ground, whereas the seismographs that recorded the wind farm and highway data were buried. Burying seismic sensors contributes to isolating a sensor from wind-coupled ground motion caused by wind-induced movement of surface objects, including the exposed sensor, or by turbulent pressures on topographic irregularities.

The highway curves show that time-of-day differences in ground motion are present at center frequencies of 4 to $10 \mathrm{~Hz}$, and day-of-week differences persist to center frequencies as high as $50 \mathrm{~Hz}$. As discussed above, the variation in highway ground motion with time of day and day of the week is interpreted to mean that cultural activity is its primary cause. 

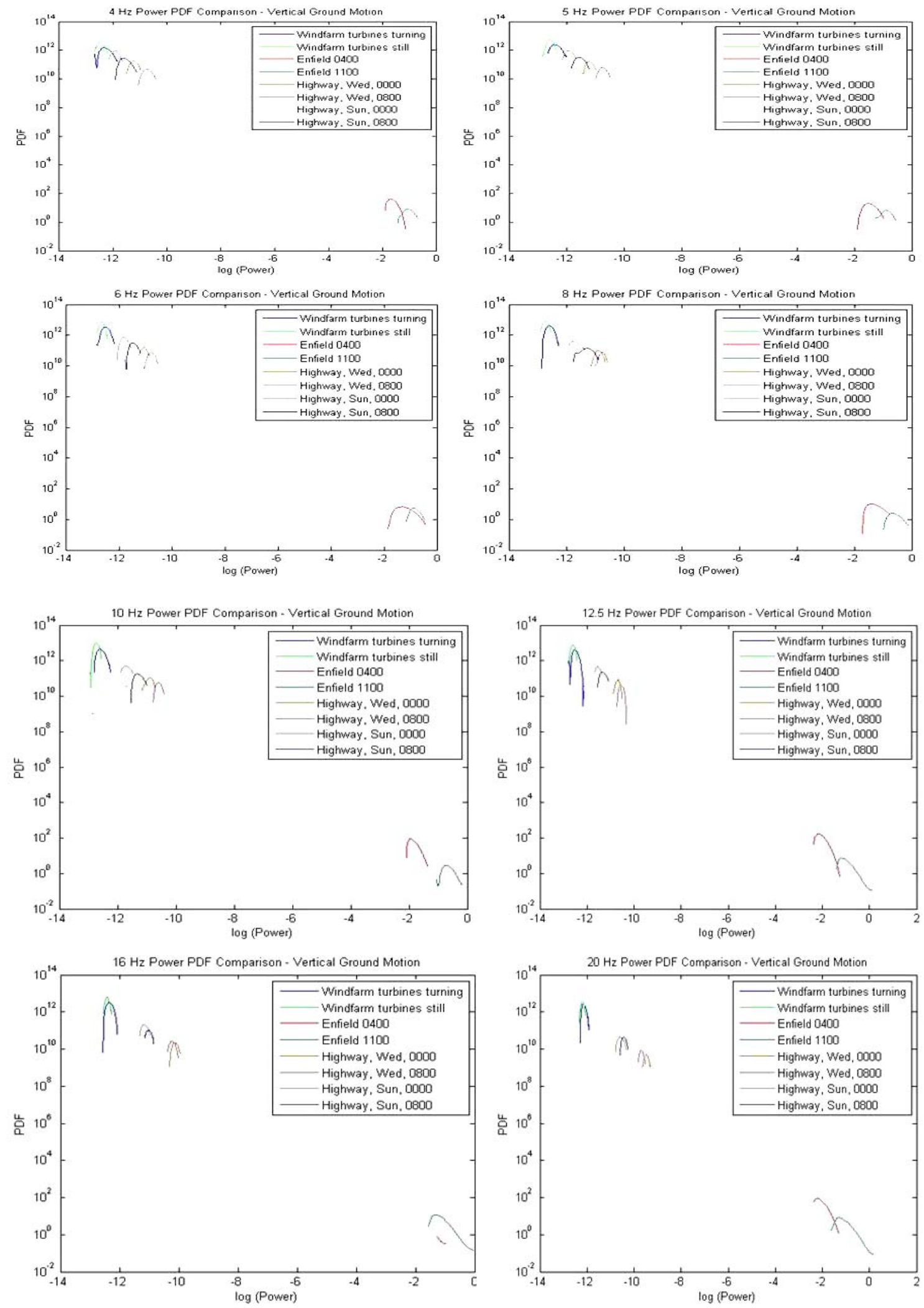

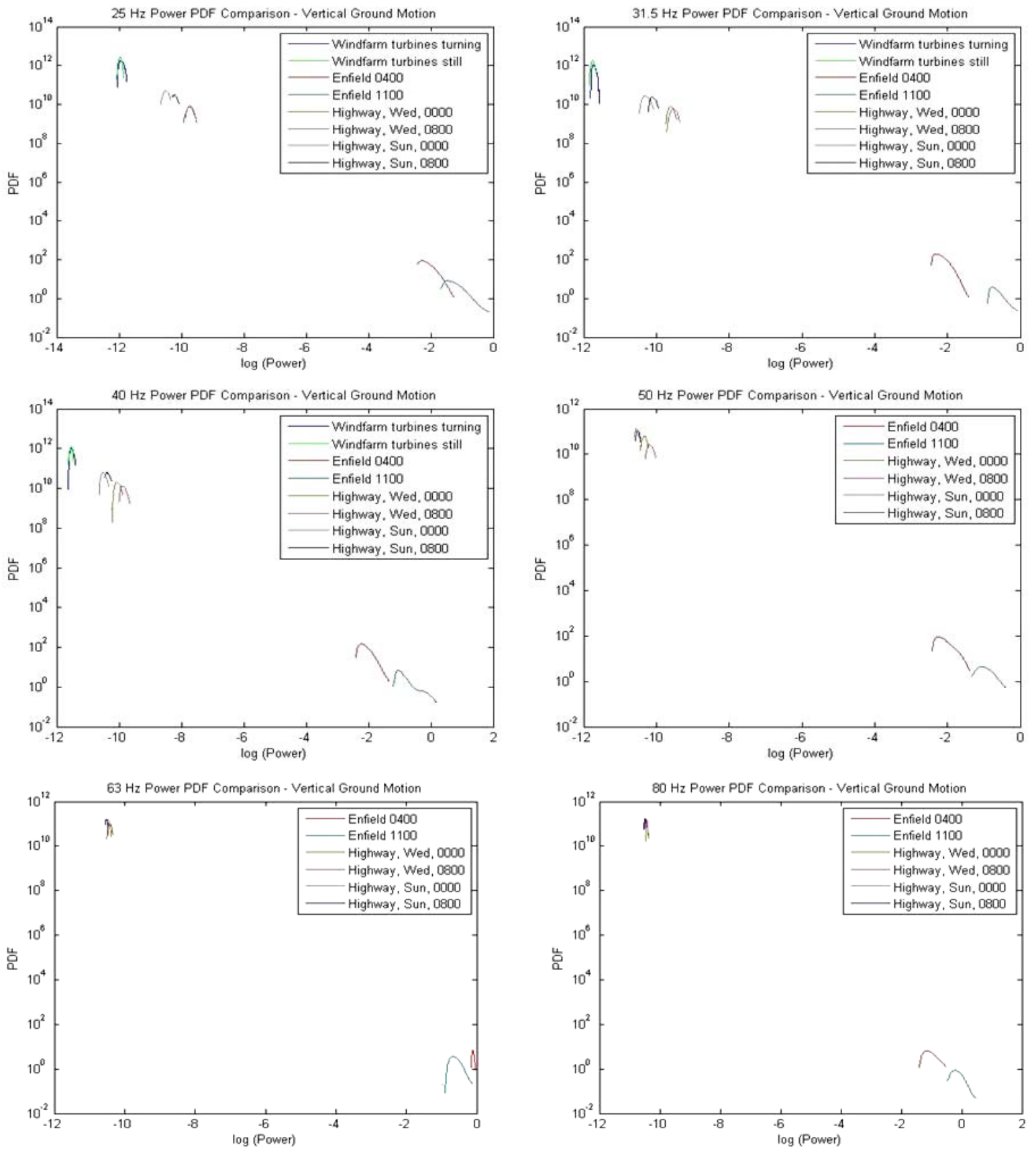

Figure 16. Composite plots of wind farm, Enfield, and highway ground motion by frequency. The PDF curves are calculated from the ninth degree polynomial coefficients, with values of power defined by the lower and upper limits presented in Tables 2 - 4 and Tables 6 - 9, Tables 10 - 12, and Tables 13 - 15 for the wind farm, Enfield, highway (15 Feb 06), and highway (19 Feb 06) PDFs, respectively. 


\section{Conclusions}

The sites selected for this investigation serve as examples of variation in seismic noise with site activity (wind farm), time of day (Enfield) and both time of day and day of the week (highway). The results presented are significant as characterizations of seismic noise at the specific sites, and as examples of actual variability in seismic noise for incorporation in simulations of ground motion.

The wind farm ground motion demonstrates the expected dependence on whether the turbines are turning. More interesting is that, despite the site's remoteness from cultural activity, its ground motion varies by frequency and orientation even when the turbines are still. When simulating ground motion for assessment of seismic sensor performance, wind farm ground motion PDFs (turbines still) would be suitable for defining seismic noise that is representative of very low cultural activity by Western standards. The wind farm PDFs (turbines still) could also be the basis of seismic noise representations for non-Western rural sites where there is little to no use of machinery.

The highway ground motion provides a useful example of culturally related variation in seismic noise by hour of the day and by day of the week. The daytime/ nighttime and weekday/ weekend differences are consistent with Western patterns of social and commercial activity. The highway PDFs also could be the basis of seismic noise representations for nonWestern sites by offsetting the highway PDFs (by hour or by day) to better match local patterns of cultural activity. For instance, the seismic noise on Sunday, the highway site's "quiet day", could be applied as generic "quiet day" seismic noise, regardless of the actual day of the week that pertained to a non-Western site. Or, the highway site's hourly seismic noise representations might be offset by $12 \mathrm{hr}$, if patterns of activity at a site of interest are inverted, i.e., more intense cultural activity at night than during the day.

Although limited to $8 \mathrm{hr}$ (0000 - 0800 local) on a single day, the Enfield ground motion analysis is especially important because it covers the broadest frequency range, 4 - $200 \mathrm{~Hz}$. The Enfield results are an excellent example of strong seismic noise for simulations of ground motion at nonurban sites. 


\section{References}

Peck, L. 2008. Overview of seismic noise and its relevance to personnel detection. ERDC/CRREL TR-08-5. Hanover, NH: U.S. Army Engineer Research and Development Center.

Sleefe, G. E., M. D. Ladd, T. S. McDonald, and G. J . Elbring. 1999. Acoustic and seismic modalities for unattended ground sensors. Sandia National Laboratories report SAND99-0762C.

Styles, P.; I. Stimpson; S. Toon; R. England; M. Wright. 2005. Microseismic and Infrasound Monitoring of Low Frequency Noise and Vibrations from Windfarms: Recommendations on the Siting of Windfarms in the Vicinity of Eskdalemuir, Scotland. Applied and Environmental Geophysics Research Group, Keele University, England. 18 J uly 2005.

van den Berg, G. P. 2004. Do wind turbines produce significant low frequency sound levels? 11th International Meeting on Low Frequency Noise and Vibration and its Control. Maastricht, The Netherlands. 30 August - 1 September 2004.

Withers, M. M.; R. C. Aster; C. J . Young; E. P. Chael. (1996). High-frequency analysis of seismic background noise as a function of wind speed and shallow depth. Bulletin Seismological Soc. America 86: 1507-1515.

Young, C. J .; E. P. Chael; M. M. Withers; R. C. Aster. (1996). A comparison of the highfrequency $(>1 \mathrm{~Hz})$ surface and subsurface noise environment at three sites in the United States. Bulletin Seismological Soc. America 86:1516-1528. 


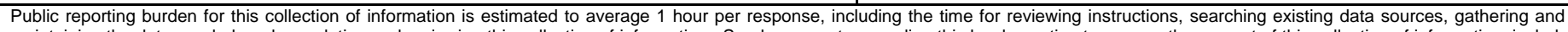

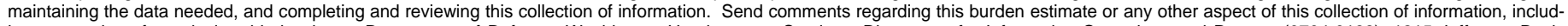

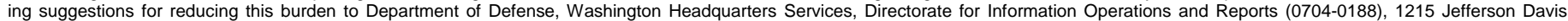

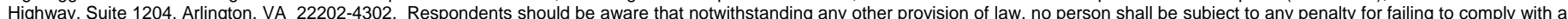
collection of information if it does not display a currently valid OMB control number. PLEASE DO NOT RETURN YOUR FORM TO THE ABOVE ADDRESS.

\begin{tabular}{l|l|l} 
1. REPORT DATE & 2. REPORT TYPE & 3. DATES COVERED (FrOm - TO)
\end{tabular}

March 2010 Technical Report

4. TITLE AND SUBTITLE

Characterization of Seismic Noise at Selected Non-Urban Sites

5a. CONTRACT NUMBER

5b. GRANT NUMBER

5c. PROGRAM ELEMENT NUMBER

6. AUTHOR(S)

5d. PROJECT NUMBER

Lindamae Peck, Peter Styles, and Sam Toon

5e. TASK NUMBER

5f. WORK UNIT NUMBER

7. PERFORMING ORGANIZATION NAME(S) AND ADDRESS(ES)

8. PERFORMING ORGANIZATION REPORT NUMBER

U.S. Army Engineer Research and Development Center (ERDC) Cold Regions Research and Engineering Laboratory (CRREL)

72 Lyme Road

Hanover, NH 03755-1290

9. SPONSORING I MONITORING AGENCY NAME(S) AND ADDRESS(ES)

ERDC/CRREL TR-10-4

10. SPONSOR/MONITOR'S ACRONYM(S)

11. SPONSOR/MONITOR'S REPORT

NUMBER(S)

12. DISTRIBUTION I AVAILABILITY STATEMENT

Approved for public release; distribution is unlimited.

\section{SUPPLEMENTARY NOTES}

\section{ABSTRACT}

Seismic noise is the ambient ground motion within which signals of interest are to be detected. Because the distinction between seismic noise and seismic signature is application dependent, the ground motion representations presented in this report serve both as characterization of seismic noise that, for example, might interfere with the detection of walking people at the sites studied, and also as seismic signatures of the cultural activity at the three sites. The sites are: a wind farm on a remote moor in Scotland, a $\sim 13$ acre field bounded by woods in a rural Enfield, NH neighborhood, and a site transitional from developed to farmland within 1 km of the 6-lane M6 motorway near Keele, England. This report documents the variability in seismic noise at the three sites with site activity (wind farm), time of day (Enfield) and both time of day and day of the week (highway).

15. SUBJECT TERMS ground motion

Seismic noise

16. SECURITY CLASSIFICATION OF:

cultural activity

\begin{tabular}{|c|c|c|c|c|}
\hline \multicolumn{3}{|c|}{ 16. SECURITY CLASSIFICATION OF: } & \multirow{2}{*}{$\begin{array}{l}\text { 17. LIMITATION } \\
\text { OF ABSTRACT } \\
\text { Unclassified }\end{array}$} & \multirow{2}{*}{$\begin{array}{c}\text { 18. NUMBER } \\
\text { OF PAGES } \\
47\end{array}$} \\
\hline $\begin{array}{l}\text { a. REPORT } \\
\text { Unclassified }\end{array}$ & $\begin{array}{l}\text { b. ABSTRACT } \\
\text { Unclassified }\end{array}$ & $\begin{array}{c}\text { c. THIS } \\
\text { PAGE } \\
\text { Unclassified }\end{array}$ & & \\
\hline
\end{tabular}

19a. NAME OF RESPONSIBLE PERSON
19b. TELEPHONE NUMBER (include area code)

